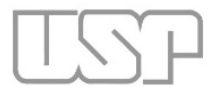

MÔNICA SILVEIRA E COSTA CHENG

\title{
DESAFIOS DA GESTÃO DA QUALIDADE DO AR: DINÂMICAS E PADRÕES DE QUALIDADE DO AR NO MUNICÍPIO DE CUBATÃO E ENTORNO
}

SÃo PAULO

2015 


\section{MÔNICA SILVEIRA E COSTA CHENG}

Desafios da gestão da qualidade do ar: Dinâmicas e padrões de qualidade do ar no Município de Cubatão e entorno

Dissertação apresentada ao Programa de PósGraduação Mestrado Profissional em Ambiente, Saúde e Sustentabilidade, da Faculdade de Saúde Pública, da Universidade de São Paulo, para a obtenção do título de Mestre em Ciências.

Orientadora: Dra . Sonia Maria Viggiani Coutinho

\section{SÃO PAULO}


É expressamente proibida a comercialização deste documento, tanto na sua forma impressa como eletrônica. Sua reprodução, total ou parcial, é permitida exclusivamente para fins acadêmicos e científicos, desde que na reprodução figure a identificação do autor, título, instituição e ano da dissertação.

\section{Catalogação da Publicação}

Serviço de Documentação XXXX

Faculdade de Saúde Pública da Universidade de São Paulo

Cheng, M.S.C.

Desafios da gestão da qualidade do ar: dinâmicas e padrões de qualidade do ar no Município de Cubatão e entorno / Mônica Silveira e Costa Cheng; Sonia Maria Viggiani Coutinho - São Paulo - 2015.

$N^{0}$ 121fls f.: il.

Dissertação (Mestrado) - Universidade de São Paulo, 2015. 
CHENG, Mônica S.C., Desafios da gestão da qualidade do ar: dinâmicas e padrões de qualidade do ar no Município de Cubatão e entorno - Faculdade de Saúde Pública da Universidade de São Paulo, São Paulo, 2015. 


\section{FOLHA DE APROVAÇÃO (DISSERTAÇÃO)}

CHENG, Mônica Silveira e Costa

Desafios da gestão da qualidade do ar: dinâmicas e padrões de qualidade do ar no Município de Cubatão e entorno

Dissertação apresentada ao Programa de Pós-Graduação Mestrado Profissional em Ambiente, Saúde e Sustentabilidade, da Faculdade de Saúde Pública, da Universidade de São Paulo, para a obtenção do título de Mestre em Ciências.

Aprovado em:

BANCA EXAMINADORA

Prof. Dr. Instituição:

Julgamento: Assinatura:

Prof. Dr. Instituição:

Julgamento: Assinatura:

Prof. Dr. Instituição:

Julgamento: Assinatura: 


\section{DEDICATÓRIA}

Dedico à minha filha Melissa e ao meu esposo James, pelo carinho, compreensão e apoio, que me motivam a buscar sempre mais desafios.

Dedico também aos meus pais, Josué (in memoriam) e Carmen, pelo exemplo de força e caráter, que com seus ensinamentos de vida e suporte nas adversidades, serviu de alicerce para minha vida. 


\section{AGRADECIMENTOS}

Ao Prof. Dr. Arlindo Philippi Jr. e Prof ${ }^{a}$. Dr ${ }^{a}$. Wanda Maria Risso Günther, pela acolhida ao Programa de Pós-Graduação Mestrado Profissional em Ambiente, Saúde e Sustentabilidade.

À Profa. Dra. Sônia Maria Viggiani Coutinho, pela orientação, dedicação, paciência , atenção à organização e aos detalhes.

À Prof". Maria da Penha Vasconcellos, minha "madrinha” neste programa, pelo suporte e disposição em contribuir com o desenvolvimento e finalização desta pesquisa. Em especial agradeço ao seu entusiasmo e incentivo, que foram de grande motivação para mim.

Ao Prof. Dr. João Vicente Assunção, Prof. Dr. Eduardo de Senzi Zancul e Prof. Dr. Moacir Ferreira da Silva pela atenção e contribuições importantes para esta dissertação.

À equipe do InovaLab@POLI, pelo suporte no desenvolvimento do projeto e aos alunos, Beatriz, Eloi, Fernanda, Pedro e Priscilla, pela seriedade e competência com que desenvolveram o desafio apresentado.

Ao Pedro Daniel pela atenção dispensada e apoio, com ajuda e orientação nas questões administrativas, durante todo o período, desde o primeiro dia.

À USIMINAS, em especial ao Eng ${ }^{\circ}$ Bruno Menezes de Melo e aos colegas da gerência de meio ambiente, pelo voto de confiança e pela oportunidade concedida.

Ao CIESP Cubatão, nas pessoas do Eng ${ }^{\circ}$ Valdir José Caobianco e Valmir Ramos Ruiz, pelo incentivo e contribuições importantes na construção desta pesquisa, bem como o apoio durante todo o projeto.

À CETESB, em especial a Agência Ambiental de Cubatão, representada pelo Eng $^{\circ}$. Marcos Cipriano e Eng ${ }^{\circ}$. Enedir Rodrigues, e à ECOVIAS, representada por Valdir Ribeiro e Raul Boff, pela colaboração.

Ao Carlos, Beatriz, Juliana e Márcia Costa Jordão, pelo tempo e atenção dedicados, com contribuições importantes e por todo o carinho a mim dedicado.

Também agradeço o carinho de todos os meus familiares e amigos, sempre presentes em todas as ocasiões, torcendo e dando o suporte que tanto precisei.

Por fim, a todos, os meus sinceros agradecimentos pela oportunidade riquíssima que me foi proporcionada. Obrigada. 


\section{RESUMO}

CHENG, M. S. C. Desafios da gestão da qualidade do ar: dinâmicas e padrões de qualidade do ar no Município de Cubatão e entorno. 2015. 121f. Dissertação (Mestrado) - Faculdade de Saúde Pública, Universidade de São Paulo, São Paulo, 2015.

O Município de Cubatão passou por mudanças significativas em seu cenário desde 1950, passando de uma região rural para industrial, com impacto ambiental significativo. Este projeto tem por objetivo analisar o conjunto de ações relacionadas à gestão ambiental da qualidade do ar, entre 1980 e 2013, no Município de Cubatão e seu entorno, considerando possibilidades de respostas na tomada de decisão e ações para controle da qualidade do ar, particularmente referente ao material particulado ( $\left.\mathrm{MP}_{10}\right)$. $\mathrm{O}$ percurso metodológico da investigação considerou: legislação referente ao período, materiais divulgados na imprensa, banco de dissertações e teses acadêmicas e etapa de pesquisa empírica, com o desenvolvimento de conceitos que equacionem as questões de tráfego de caminhões e qualidade do ar em Cubatão e entorno. Como resultado desta pesquisa pôde-se identificar os principais elementos-chave a serem considerados e propor protótipo, com uma nova abordagem logística para o transporte de grãos na região, que pode auxiliar no controle sobre os índices de poluição do ar, em específico, o parâmetro material particulado $\left(\mathrm{MP}_{10}\right)$.

Palavras-chave: Município de Cubatão, Gestão Pública, Material Particulado, Qualidade do Ar 


\section{ABSTRACT}

CHENG, M.S.C. Challenges of the air quality management: dynamics and standards of the air quality in the City of Cubatão and surroundings. 2015. 121f. Master's Thesis - School of Public Health, University of São Paulo, São Paulo, 2015.

The scenario of the City of Cubatão has changed significantly since 1950, going from a rural region to an industrial one, with a significant environmental impact. The objective of this project is to analyze the actions related to the environmental management of air quality, from 1980 to 2013, in the City of Cubatão and its surrounding, considering potential responses in the decision-making and actions for air quality control, especially regarding the particulate matter $\left(\mathrm{PM}_{10}\right)$. The research methodology has taken into consideration the legislation for the period, press publications, academic dissertations and theses database, and an empirical research stage, with the development of concepts to assess the truck traffic and air quality issues in Cubatão and surroundings. As a result of this research, the key elements to be taken into consideration were identified and a prototype, with a new approach on the grain transport logistics in the region, was proposed, which can assist the control of air pollution index, specially, the particulate matter parameter $\left(\mathrm{PM}_{10}\right)$.

Key words: City of Cubatão, Public Management, Particulate Matter, Air Quality. 


\section{LISTA DE SIGLAS E ABREVIATURAS}

ALL - América Latina Logística do Brasil Ltda.

ANEC - Associação Nacional de Exportadores de Cereais

ANTT - Agência Nacional de Transportes Terrestres

BC - Black Carbon - carbono elementar ou orgânico

CETESB - Companhia Ambiental do Estado de São Paulo

CIDE - Centro de Integração e Desenvolvimento Empresarial da Baixada Santista

CIESP - Centro das Indústrias do Estado de São Paulo

CIESP - Cubatão- Centro das Indústrias do Estado de São Paulo - Regional Cubatão

CINCU - Complexo Intermodal de Cubatão

CMT - Companhia Municipal de Trânsito (Cubatão)

CODESP - Companhia Docas do Estado de São Paulo

CONSEMA - Conselho Estadual de Meio Ambiente

COSIPA - Companhia Siderúrgica Paulista

CPDOC - Centro de Pesquisa e Documentação de História Contemporânea do Brasil

CSN - Companhia Siderúrgica Nacional

DAEE - Departamento de águas e energia elétrica (Estado de São Paulo)

ECOVIAS - Concessionário Ecovias dos Imigrantes S/A

ECOPATIO - Ecopatio logística Cubatão

ELOG - Gestão de logística integrada

EMAE - Empresa Municipal de Águas e Energia (Cubatão)

EPD - Environmental Pollution Data

FCA - Ferrovia Centro-Atlântica

FIESP - Federação das Indústrias do Estado de São Paulo

FGV - Faculdades Getúlio Vargas

FOSFERTIL - Fertilizantes fosfatados S.A. (Atual VALEFERT)

GPS - Global Positioning System

IBAMA - Instituto Brasileiro do Meio Ambiente e dos Recursos Naturais Renováveis

IBGE - Instituto Brasileiro de Geografia e Estatística

Internet - Rede Internacional de Computadores

LILACS - Literatura Latino-Americana e do Caribe em Ciências da Saúde

MAA - Média Aritmética Anual

PIB - Produto Interno Bruto

PCPV - Plano de Controle de Poluição Veicular 
PETROBRAS - Petróleo Brasileiro S/A

PIB - Produto Interno Bruto

PND II - Segundo Plano Nacional de Desenvolvimento

POLI USP - Escola Politécnica da Universidade de São Paulo

PQAr - Padrões de Qualidade do Ar

PREFE - Plano de Redução de Emissões de Fontes Estacionárias

PROCOP - Programa de Controle de Poluição (CETESB)

OMS - Organização Mundial de Saúde

ONU - Organização das Nações Unidas

RCQA - Regiões de Controle de Qualidade do Ar

RFFSA - Rede Ferroviária Federal S.A.

RMBS - Região Metropolitana da Baixada Santista

RMSP - Região Metropolitana de São Paulo

SAI - Sistema Anchieta - Imigrantes

SEMA - Secretaria Especial de Meio Ambiente

SEP - Secretaria Especial dos Portos

UNISANTOS - Universidade Católica de Santos

USIMINAS - Usinas Siderúrgicas de Minas Gerais S.A.

USP - Universidade de São Paulo

ULTRAFERTIL - empresa de fertilizantes - antiga FOSFERTIL

UR - Umidade relativa do ar

VALEFERT - Vale Fertilizantes

VLI - Valor da Logística Integrada 


\section{LISTA DE ILUSTRAÇÕES}

Figura 1: Etapas da pesquisa

Figura 2: Identificação de fatores que interferem na qualidade do ar da região

Figura 3: Necessidades do persona criado - "Gestor otimizador da qualidade do Ar"

Figura 4: Categorização de ideias

Figura 5: Evolução das exportações de grãos pelo Porto de Santos até 2013

Figura 6: Sazonalidade das exportações pelo Porto de Santos - 2013

Figura 7: Representação do "Super Waze"

Figura 8: Prototipagem do dark horse

Figura 9: Baixada Santista, assinalado o Município de Cubatão e o Polo Industrial

Figura 10: Polo Industrial - década de 1970

Figura 11: Polo Industrial - início do inventário das fontes de emissão atmosférica

Figura 12: Redução de emissões atmosféricas - 1983 a 2013

Figura 13: Evolução das concentrações médias anuais $\left(\mathrm{MP}_{10}\right)$, em Cubatão - Vila Parisi no período de 1982 a 2013

Figura 14: Recebimentos, em toneladas, estratificados conforme o modal de transporte, Polo Industrial de Cubatão

Figura 15: Expedições, em toneladas, estratificados conforme o modal de transporte, Polo Industrial de Cubatão

Figura 16: Congestionamento registrado em 24 de maio de 2013, em Cubatão

Figura 17: Congestionamento na Conego Domenico Rangoni, em 28/05/2013

Figura 18: Pátio regulador em Cubatão

Figura 19: Cenário na região próxima à Estação medidora V. Parisi (2010)

Figura 20: Vista da estação medidora da V. Parisi durante campanha de limpeza

Figura 21: $\mathrm{MP}_{10}$ - Distribuição percentual da qualidade do ar - Cubatão - V. Parisi, Rede automática (maio a setembro)

Figura 22: $\mathrm{MP}_{10}$ - Distribuição percentual da qualidade do ar - Cubatão - V. Mogi, Rede automática (maio a setembro)

Figura 23: $\mathrm{MP}_{10}$ - Distribuição percentual da qualidade do ar - Cubatão - Centro, Rede automática (maio a setembro)

Figura 24: Atividades de umectação das pistas com caminhão pipa (24 horas)

Figura 25: Atividades de varrição das pistas nas vias de acesso ao Polo Industrial

Figura 26: Sistema de cores para demonstrar alterações das condições da região

Figura 27: Tamanho de setas para demonstrar a intensidade dos impactos identificados 
Figura 28: Cenário 1951 - 1980 - Origem do problema - episódios críticos

Figura 29: Cenário 1981 - 2000 - Implantação de ações de gestão - controle

Figura 30: Cenário 2001 - 2013 - Alteração da dinâmica - qualidade do ar

Figura 31: Simulação com transporte de um produto por vez com vazão de 4.000 ton/h. “ExpSoja” e "ExpMilho" representam a exportação esperada, com o transporte pelo duto nas séries "Soja" e "Milho"

Figura 32: Simulação do tráfego semanal de caminhões de soja e milho antes do duto (linha que representa a série s/duto) e depois de sua implantação, discriminando a carga transportada (colunas)

Figura 33: Vista 3D dos terminais e saída das esteiras

Figura 34: Traçado das esteiras, chegando aos dois lados do estuário de Santos

Figura 35: Terminal Alto da Serra

Figura 36: Sistema Pipe Conveyor Belt da Bridgestone

\section{LISTA DE QUADROS}

Quadro 1: Classificação do índice da qualidade do ar, para o parâmetro $\mathrm{MP}_{10}$, com destaque para as condições que passam a ser consideradas como episódios críticos

Quadro 2: Fontes, características e efeitos dos principais poluentes da atmosfera

Quadro 3: Padrões de Qualidade do Ar e Critérios para Episódios Críticos de Poluição, com destaque para o parâmetro material particulado $\mathrm{MP}_{10}$, válidos até 2012 para o Estado de São Paulo

Quadro 4: Episódios Críticos de Poluição e seu significado, com destaque para o parâmetro material particulado $\mathrm{MP}_{10}$, válidos até 2012 para o Estado de São Paulo

Quadro 5: Número de estados de Atenção, Alerta e Emergência declarados em Vila Parisi (1986 -2002), com destaque em negrito para o período em que não ocorreram estados de "Alerta” e/ou "Emergência”

Quadro 6: Padrões Estaduais de Qualidade do Ar (Decreto Estadual n ${ }^{\circ} 59.113$ de 23/04/2013) com destaque para o parâmetro $\mathrm{MP}_{10}$

Quadro 7: Consolidação da criticidade dos cenários em Cubatão e entorno

\section{LISTA DE TABELAS}

Tabela 1: Eficiência energética entre as modalidades de transporte de carga 


\section{SUMARIO}

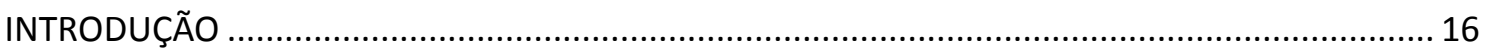

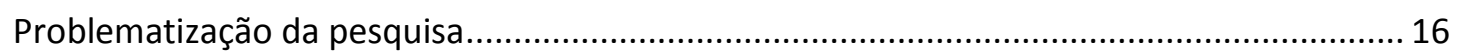

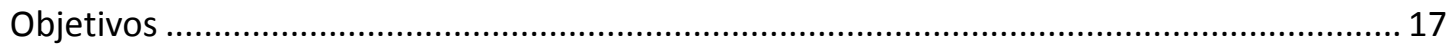

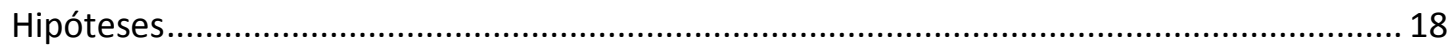

Breve apresentação dos métodos adotados........................................................................ 18

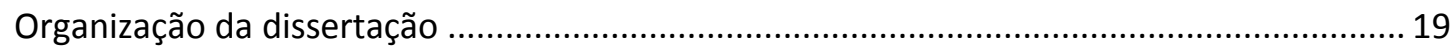

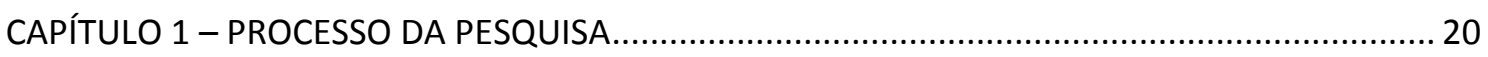

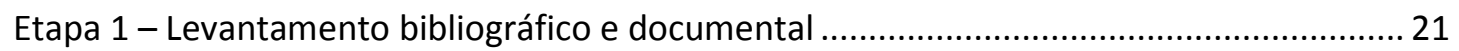

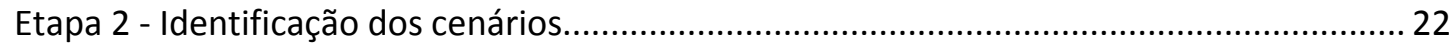

Etapa 3 - Análise de cenários e definição de elementos-chave ................................................. 23

Etapa 4 - Identificação de ferramentas e desenvolvimento de protótipo................................ 24

Etapa 5: Conclusões e recomendações.......................................................................... 29

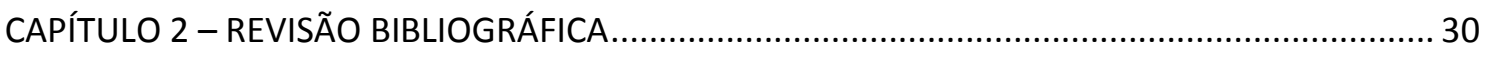

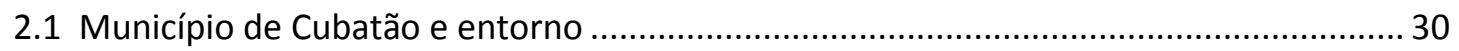

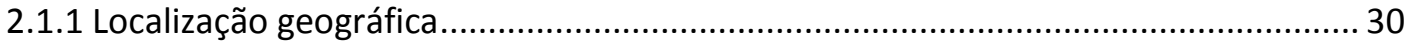

2.1.2 Desenvolvimento econômico e mudanças na dinâmica da região .............................. 30

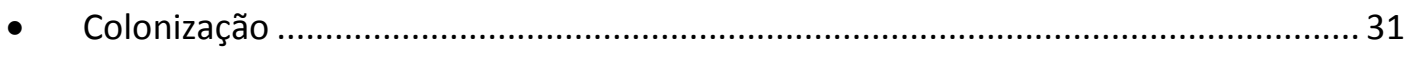

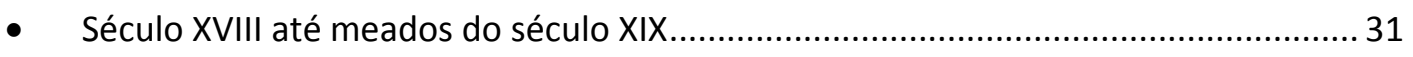

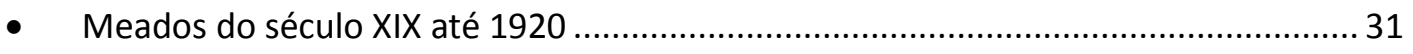

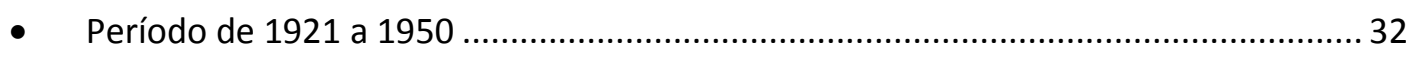

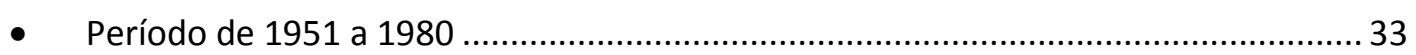

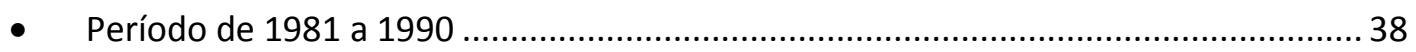

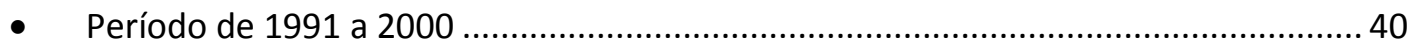

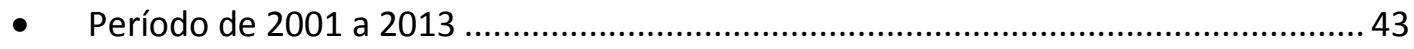


2.2 Gestão da qualidade do ar no Estado de São Paulo...................................................... 51

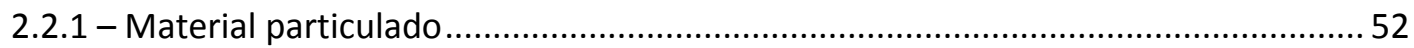

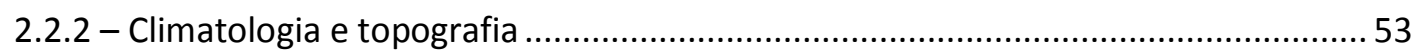

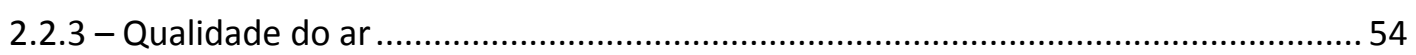

- Padrões de qualidade do ar - válidos até 2012 ..........................................................5 54

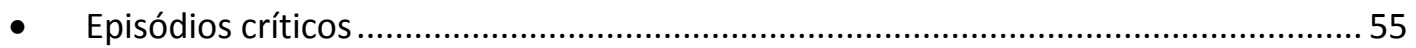

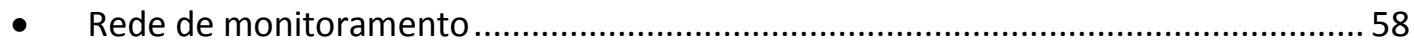

- Classificação das estações telemétricas no Estado de São Paulo ..................................61 61

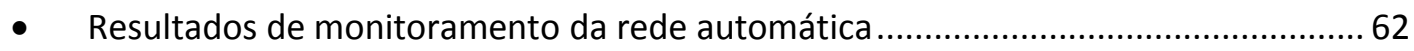

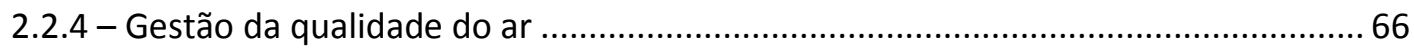

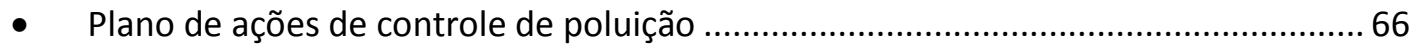

- $\quad$ Plano de ações de emergência - episódios críticos ..................................................... 68

2.2.5 - Novos padrões de qualidade do ar................................................................... 71

- Monitoramento 2013 - os novos padrões de qualidade do ar..................................... 72

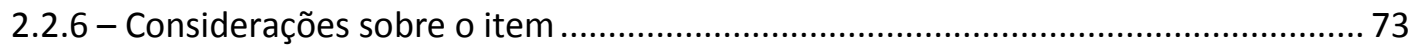

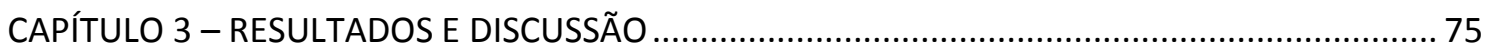

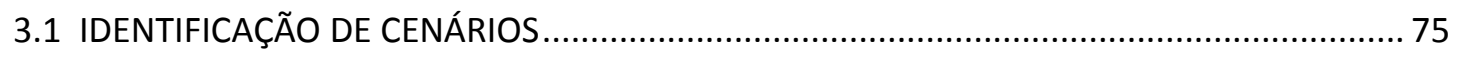

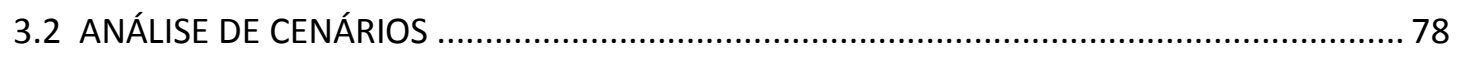

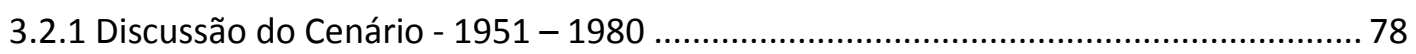

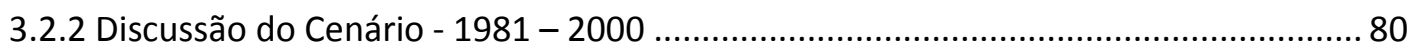

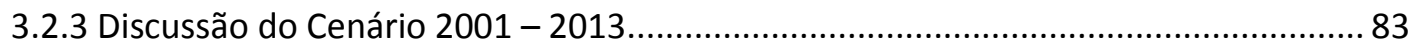

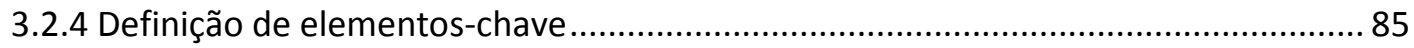

3.3 IDENTIFICAÇÃO DE FERRAMENTAS E DESENVOLVIMENTO DE PROTÓTIPO ....................... 86

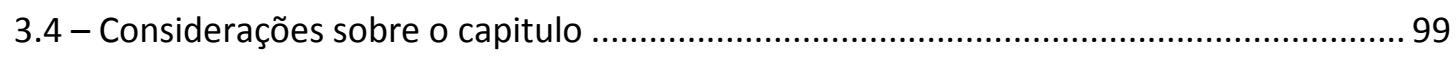

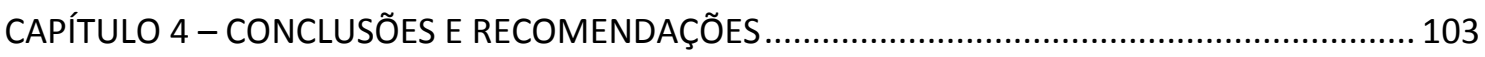




\section{INTRODUÇÃO}

Os desafios da gestão da qualidade do ar em Cubatão, as consequências da poluição do ar e seus efeitos são bastante conhecidos, tendo sido identificados estudos sobre o tema, desde a década de 1980.

A mudança das atividades, fluxo e cenários de ocupação do Município, foram ocorrendo, e observou-se que as mudanças foram identificadas nestes estudos, porém estas não foram consideradas, de uma forma sistemática, na definição de ações de controle da poluição do ar.

\section{Problematização da pesquisa}

Nos últimos anos, a alteração da dinâmica ocorrida na região resultante de mudanças das atividades econômicas, fluxos e cenários de ocupação do Município foi identificada, porém não considerada, de uma forma sistemática, na definição de ações de controle para evitar episódios críticos de poluição do ar.

Foram pesquisados diversos estudos sobre o tema, especialmente os desenvolvidos pela Companhia Ambiental do Estado de São Paulo (CETESB), versando sobre a qualidade do ar, dispersão de poluentes e caracterização dos poluentes na atmosfera (BALBINO, 2008; CETESB, 1996; CETESB, 1998a; CETESB, 1998b; CETESB, série a 2001 2013; CETESB, série b 2004 - 2013; CETESB, 2013d; FERLING, 2008; FURLAN, 1998; HABERMANN et al, 2012; LOPES, 2001; NASCIMENTO, 2010; NATALI, 2008; SANTOS, 2010; SILVA, 2013; VALARINI, 2011).

Encontram-se também temas referentes aos efeitos da poluição sobre a saúde da população exposta (COLOMBINI, 2007; COELHO, 2009; GUANABARA a, 2011; GUANABARA b, 2001; SILVA, 2010; YANAGI, 2010) e, após o ano 2000, foram desenvolvidas com maior frequência pesquisas referentes a emissões veiculares e seus efeitos sobre a saúde da população exposta (HABERMANN et al, 2011; HABERMANN et al, 2012; HABERMANN, 2012; LEMOS, 2010; MARTINS, 2009; OGLIARI, 2011; RIBEIRO, 2011; SILVA, 2007; TOLEDO, 2010) com concentração maior de informações aplicáveis ao Município de São Paulo ou à Região Metropolitana de São Paulo. Alguns estudos focam nas ações de gestão adotadas e seus resultados para controle das emissões veiculares (CETESB, série c 2011-2013; CETESB, 2014a; CETESB, 2014b; CIDE, 2006; FERREIRA, 2007; FIESP, 2008; GIARETTA, 2011; HADDAD, 2007; MAGLIO, 2005; NUNES, 2010; VENDRAMINI, 2010).

Foram identificadas pesquisas relacionadas à utilização de ferramentas e modelos como instrumentos de gestão para controle ambiental (BARNEY et al, 1995; CUMMING, 2013; FERREIRA, 2007; FIGUEIREDO et al, 2014; FREITAS, 2006; GIBSON , 2006; JONES et al, 2011; MARRO et al, 2009; SANTOS, 2009; POPE et al, 2013). Porém, embora tenham sido identificados documentos e pesquisas relacionados a ações de gestão e qualidade do ar em Cubatão, à nova dinâmica da região, e à utilização de 
ferramentas e modelos como instrumentos de gestão para controle ambiental, não foram encontrados estudos que relacionassem estas ações de gestão e qualidade do ar em função da variação da dinâmica que vem ocorrendo no Município de Cubatão e seu entorno desde 2000.

Entende-se que o Município de Cubatão não pode ser estudado dissociado de seu entorno. O Município possui um importante Polo Industrial instalado, e sofre também a influência das atividades do Porto de Santos, com tráfego intenso de caminhões, associado ao fato de ser uma das vias de acesso às praias do litoral Centro (Cubatão, Santos, São Vicente, Guarujá e Bertioga) e litoral Sul do Estado de São Paulo (Praia Grande, Mongaguá, Itanhaém e Peruíbe).

Sabe-se que vêm ocorrendo mudanças de atividades, fluxos e cenários de ocupação no Município de Cubatão e seu entorno, mas estas mudanças, como a inserção da atividade logística para apoio ao Porto de Santos e o aumento da intensidade de movimentação de veículos nas estradas e entorno das estações medidoras da qualidade do ar, não foram acompanhadas de ações de gestão em um mesmo ritmo.

Este projeto tem por objetivo analisar o conjunto de ações relacionadas à gestão ambiental da qualidade do ar, entre 1980 e 2013, no Município de Cubatão e seu entorno, considerando possibilidades de respostas na tomada de decisão e ações para controle da qualidade do ar, particularmente referente ao parâmetro material particulado $\left(\mathrm{MP}_{10}\right)$.

O diferencial desta pesquisa, portanto, consiste em considerar, além dos indicadores da qualidade do ar e questões pontuais, a relação entre a alteração da dinâmica existente no Município de Cubatão e seu entorno, para que as ações de gestão para controle da qualidade do ar sejam adotadas de forma que acompanhem estas alterações com estratégias e ações no âmbito das políticas públicas.

\section{Objetivos}

\section{Objetivo geral}

Analisar o conjunto de ações relacionadas à gestão ambiental da qualidade do ar, entre 1980 e 2013, no Município de Cubatão e seu entorno, considerando possibilidades de respostas na tomada de decisão e ações para controle da qualidade do ar, particularmente referente ao material particulado $\left(\mathrm{MP}_{10}\right)$.

\section{Objetivos específicos}

- Identificar e analisar os cenários de ocupação e dinâmica do Município de Cubatão e a evolução da qualidade do ar, considerando, como parâmetro, o material particulado $\left(\mathrm{MP}_{10}\right)$, entre 1980 a 2013. 
- Descrever os elementos-chave que possibilitem identificar e caracterizar situações que possam levar a eventos críticos de poluição do ar na localidade do estudo para servir de base para tomada de decisões e elaboração de estratégias de prevenção ou de mitigação.

- Propor modelo tecnológico de solução que possa subsidiar ações de gestão na região, por meio de protótipo conceitual, considerando a associação de tráfego de caminhões e qualidade do ar em Cubatão e entorno.

\section{Hipóteses}

A motivação desta pesquisa decorre da observação da autora em sua atuação profissional no Polo Industrial de Cubatão, em relação aos desdobramentos das ações de gestão da qualidade do ar em Cubatão e entorno, e seus impactos no ambiente e na qualidade de vida, levando-a a indagações sobre:

1. As ações para controle da poluição do ar nos casos de episódios críticos de poluição, adotadas atualmente, são suficientes e adequadas à nova dinâmica da região?

2. Qual a representatividade dos índices monitorados atualmente na composição das políticas públicas considerando as emissões decorrentes do tráfego de veículos?

3. As condições atuais, comparando com as condições do passado, de forma a propor novas diretrizes ou ações de gestão ambiental estão acompanhando as mudanças da região?

Com base nestas indagações tem-se como hipótese geral que as Políticas Públicas de Controle Ambiental são insuficientes para abranger a dinâmica atual do Município de Cubatão e seu entorno.

Também tem como hipótese, que os índices monitorados atualmente em Cubatão não consideram de forma efetiva outras fontes poluidoras, com destaque para as emissões decorrentes do tráfego de veículos.

\section{Breve apresentação dos métodos adotados}

O percurso metodológico da investigação considerou: legislação referente ao período, materiais divulgados na imprensa, banco de dissertações e teses acadêmicas e elaboração de protótipo conceitual sobre sistema logístico de transporte de veículos de médio e grande porte. 


\section{Organização da dissertação}

O capítulo 1 delineia a abordagem metodológica e discorre sobre as etapas da pesquisa. O capítulo 2 trata da revisão bibliográfica, que envolve a caracterização do desenvolvimento econômico do Município de Cubatão e entorno e a gestão da qualidade do ar no Estado de São Paulo e no Município de Cubatão. O capítulo 3 traz os resultados e discussão sobre a identificação dos diferentes cenários decorrentes das modificações na dinâmica da região ao longo do tempo, a análise destes cenários em relação aos efeitos sobre a qualidade do ar e as ações de gestão adotadas, com a definição dos elementos-chave e, desenvolvimento de protótipo tecnológico conceitual. O capítulo 4 discorre sobre as conclusões e recomendações, consolidando as discussões dos capítulos anteriores. 


\section{CAPÍTULO 1 - PROCESSO DA PESQUISA}

As etapas da pesquisa (Figura 1) englobaram análise de estudos e documentos referentes ao Município de Cubatão e entorno, e sua dinâmica de ocupação ao longo do tempo; estudos referentes aos problemas associados a emissões atmosféricas, principalmente aqueles relacionados à ocorrência de episódios críticos de poluição do ar durante o período de 1980 a 2013; ações de gestão adotadas para controle da poluição do ar; matérias veiculadas pela imprensa local e nacional; legislação pertinente e, diretrizes de governo que possam ter impactado na região. A etapa de pesquisa empírica, foi realizada em parceria com a Escola Politécnica da USP, por meio da disciplina "Desenvolvimento Integrado de Produtos", com o apoio do laboratório InovaLab@POLI, tendo por objetivo desenvolver protótipo que equacione as questões associadas ao tráfego de caminhões e qualidade do ar em Cubatão e entorno.

Figura 1: Etapas da pesquisa

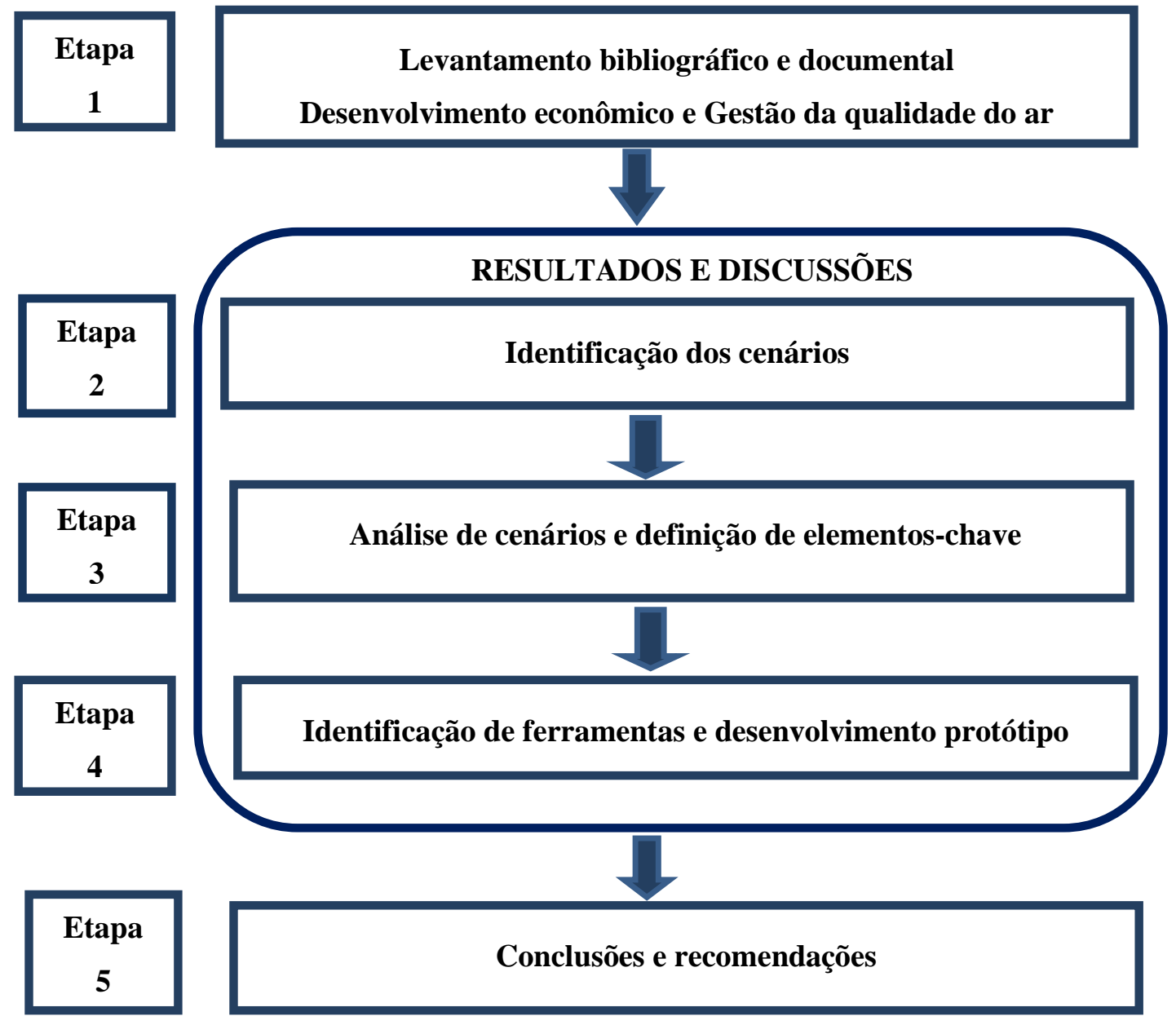

Fonte: elaboração própria 


\section{Etapa 1 - Levantamento bibliográfico e documental}

Foram abordadas três dimensões de estudo, quais sejam as diretrizes de desenvolvimento que pudessem influenciar no Município de Cubatão e seu entorno, as alterações na dinâmica da região ao longo do tempo e o histórico da qualidade do ar em Cubatão. Estas três dimensões pesquisadas buscaram responder ao primeiro objetivo específico, de forma a contemplar as mudanças ocorridas na região até o período atual (2013), considerando os cenários de ocupação do Município e seus desdobramentos em relação à evolução da qualidade do ar, para o parâmetro “material particulado” $\left(\mathrm{MP}_{10}\right)$. Também foram identificadas as ações de gestão adotadas durante os episódios críticos de poluição do ar, no período de 1980 a 2013, considerando consulta à legislação específica e informações de entidades da sociedade civil, que possibilitou a análise das transformações ocorridas no período e a discussão sobre a compatibilidade destas ações de controle com a situação atual.

A revisão bibliográfica, iniciada em maio de 2013, teve por base banco de dados LILACS (Literatura Latino-Americana e do Caribe em Ciências da Saúde), da Biblioteca Virtual em Saúde - Universidade de São Paulo, a partir dos descritores relacionados abaixo, que interagem entre as três dimensões adotadas nesta pesquisa.

a) Descritores "legislacao ambiental" [Descritor de assunto] and "BRASIL" [País, ano de publicação], obteve-se um total de 154 referências dos mais variados temas como mineração, saneamento básico, plantio de transgênicos, vigilância sanitária, segurança do trabalho, sendo somente 53 selecionadas para leitura mais detalhada, por tratarem de temas referentes a bacias aéreas, gestão de qualidade do ar, gestão e sustentabilidade, poluição atmosférica e exposição humana e, evolução do direito ambiental. Destas, nem todas foram consideradas neste estudo, pois foi dado destaque nos documentos referentes a ações de gestão ambiental e controle de poluição atmosférica.

b) Descritores "AR" or "controle da qualidade do AR" or "criterios de qualidade do AR" or "efeitos da contaminacao do AR" or "fontes de poluicao do AR" or "modelos de qualidade do AR" or "monitoramento do AR" or "movimentacao do AR" or "normas de qualidade do AR" or "particulas no AR" or "poluentes do AR" or "poluicao do AR" or "qualidade do AR" or "revitalizacao do AR" [Descritor de assunto] and (política) or "politica" or "politica ambiental" or "politica ambiental municipal" or "politica de conservacao do ambiente" or "politica institucional" or "politica nacional de vigilancia sanitaria" or "formulacao de politicas" or "organizacao governamental e politicas" or "politicas publicas" or "politicas publicas de saude" [Descritor de assunto], visando buscar estudos referentes a controle de qualidade do ar associados a políticas públicas. Foram identificados 21 estudos, porém nem todos foram considerados nesta pesquisa, pelo fato de alguns estudos estarem associados à discussão sobre os efeitos da poluição do ar sobre a saúde da população, desenvolvimento de legislação ambiental em geral ou discussão sobre outros temas envolvendo aspectos ambientais como qualidade das 
águas e solo. Para esta dissertação foram utilizados documentos que consideram as medidas de gestão já adotadas, para controle de poluição atmosférica em geral e o controle da poluição associado ao tráfego de veículos.

c) Descritores "TRANSPORTES/EC" or "TRANSPORTES/HI" or "TRANSPORTES/LJ" or "TRANSPORTES/SN" [Descritor de assunto], com o objetivo de buscar estudos relacionados ao tema, foram identificados 25 estudos. Destes, nem todos foram considerados, uma vez que tratavam na sua maioria de estudos sobre acidentes de trânsito, sobre as condições psicológicas de motoristas e doenças de trabalho, tendo sido considerados aqueles estudos voltados à gestão da logística de transporte.

Para o resgate da história do desenvolvimento da região, foram consultados livros e materiais de divulgação publicados pelo Centro Integrado de Desenvolvimento Econômico da Baixada Santista (CIDE), pelo Centro das Indústrias do Estado de São Paulo - regional Cubatão (CIESP-Cubatão), pela Federação das Indústrias do Estado de São Paulo (FIESP) e por publicação da Universidade Católica de Santos (UNISANTOS).

Foram também consultadas notícias da época, relacionadas à poluição de Cubatão e aos planos de governo e suas diretrizes, em sítios de pesquisa na Rede Internacional de Computadores (Internet), principalmente aquelas relacionadas ao Município de Cubatão, poluição em Cubatão, tráfego em Cubatão, Porto de Santos e Pátios reguladores de carga em Cubatão.

Referências históricas e ações adotadas para a gestão ambiental no Município de Cubatão foram levantadas por meio de informações junto aos sítios da Prefeitura Municipal de Cubatão, da Companhia Ambiental do Estado de São Paulo - CETESB, Instituto Brasileiro do Meio Ambiente e dos Recursos Naturais Renováveis - IBAMA, Governo do Estado de São Paulo, Companhia Docas do Estado de São Paulo CODESP e sítios do Governo Federal.

\section{Etapa 2 - Identificação dos cenários}

Para a identificação dos cenários foram coletadas informações, seleção de fatos marcantes relevantes para pesquisa e o período em que estes ocorreram. Os dados foram levantados por meio de revisão e organização da literatura identificada na etapa anterior, de forma a identificar os fatos principais ao longo dos períodos analisados.

As informações significativas decorrentes do levantamento bibliográfico foram agrupadas e, estabelecida uma legenda de formas e cores. Esta legenda foi atribuída ao município de Cubatão, de acordo com a alteração de vocação econômica ocorrida ao longo do tempo, analisando a compatibilidade destas em relação aos recursos e espaços disponíveis na região. A consolidação dos fatos históricos de Cubatão, as consequências e a compatibilidade do desenvolvimento com o Município, constam do "APÊNDICE A” desta dissertação. Nesta análise de compatibilidade, observou-se que, a intensidade 
das ações adotadas na região levaram a consequências significativas, quando utilizado como referência, os resultados dos índices de qualidade do ar.

Analisando os fatos compilados no quadro constante do APÊNDICE A foi possível identificar os principais fatos de interesse para esta pesquisa. De forma a facilitar a visualização dos resultados, foi elaborado um sistema de símbolos para denotar a criticidade da condição do Município de Cubatão e entorno, e a intensidade com que as ações, alterações na dinâmica e consequências foram tomando forma no decorrer dos anos. Foram criados então "sinalizadores" de tendência que permitiu agrupar períodos distintos na história do Município de Cubatão e as mudanças significativas na região, em decorrência de ações e reações implantadas. Com o objetivo de melhor visualizar as alterações identificadas em Cubatão e o período em que estas ocorreram, as informações coletadas foram transformadas em figuras. Desta forma foram identificados períodos em que ocorreram as alterações mais significativas para esta pesquisa. Estes períodos foram aqui denominados como "Cenários”.

\section{Etapa 3 - Análise de cenários e definição de elementos- chave}

Uma vez estabelecidos os cenários, procedeu-se à análise individual de cada um, tendo como critério as ações que refletiram negativa ou positivamente na evolução da qualidade do ar em Cubatão, para o parâmetro material particulado $\mathrm{MP}_{10}$, que é o parâmetro crítico, principalmente na região do Polo Industrial.

Comparando-se os cenários, identificou-se que ao longo do tempo, as interações entre diretrizes de governo, dinâmica e qualidade do ar começavam a apresentar incompatibilidades. Observou-se nesta etapa que as ações e reações adotadas em um determinado cenário, se repetiam nos cenários seguintes, como as mudanças nas diretrizes econômicas e ambientais, afetando a dinâmica de Cubatão e região, refletindo também sobre a qualidade do ar em Cubatão. Esta similaridade na interação entre os cenários, permitiu identificar para o Município de Cubatão, quatro elementos-chave quais sejam: "Planos e diretrizes de Ação", "Dinâmica de ocupação”, Qualidade do ar” e "Planos de reação".

Para definição dos elementos-chave foram levadas em consideração as situações que caracterizam um potencial de influência nos índices monitorados para o parâmetro material particulado ( $\left.\mathrm{MP}_{10}\right)$, que, para o caso de Cubatão (na região do Polo Industrial), é o parâmetro crítico. Foram considerados como referência, para identificar as alterações da qualidade do ar, dados medidos a partir da década de 1980, período em que se iniciou a operação das estações medidoras, realizado pela CETESB. 


\section{Etapa 4 - Identificação de ferramentas e desenvolvimento de protótipo}

Após a identificação dos elementos-chave, propôs-se a discussão de uma solução tecnológica conceitual para o cenário que se delineava em 2013, considerando a interação entre os elementos-chave identificados.

Assim ocorreu a pesquisa sobre o desenvolvimento de um protótipo em parceria com a Escola Politécnica, com apoio do InovaLab@POLI ${ }^{1}$. O objetivo foi a criação de uma ferramenta que levasse em consideração uma conceituação teórica e prática para inovação como solução ao problema. Para isso foi constituída uma equipe interdisciplinar composta pela pesquisadora, professores da Faculdade de Saúde Pública, professores da Escola Politécnica, monitores e cinco alunos de graduação de diversos cursos da USP ${ }^{2}$ matriculados na disciplina "Desenvolvimento Integrado de Produtos”. A participação da pesquisadora neste processo deu-se na definição do problema, escopo do projeto (apresentação dos elementos-chave a serem considerados), e acompanhamento do desenvolvimento e resultados, envolvendo reuniões e comunicação com o grupo.

O método de desenvolvimento do protótipo utilizado foi o design thinking, entendido por Pinheiro (2010), citado por KIELING et al (2013, p.08), como “uma abordagem para problemas complexos focada no uso da criatividade e da empatia, e que incentiva a participação de usuários finais na criação de soluções que já nascem mais adaptadas e, por isso, possuem maiores índices de adoção e maior potencial de serem catapultadas ao patamar de inovação"

Este método ocorreu nas seguintes etapas: conceituação do problema, desenvolvimento de persona, definição das necessidades dos usuários - user needs, identificação de experiências bem sucedidas - benchmarking, entrevistas, ideação, protótipo da função crítica, protótipo dark horse e protótipo final.

Para a conceituação do problema, todas as atividades que interferem na qualidade do ar em Cubatão e entorno foram identificadas (Figura 2) para, em seguida, ser definida a persona.

\footnotetext{
${ }^{1}$ O InovaLab@POLI é um laboratório multidisciplinar que oferece recursos avançados para projetos de engenharia (softwares, hardware, impressoras $3 D$, oficinas mecânica $e$ eletrônica), com acesso livre para alunos de graduação da Escola Politécnica da Universidade de São Paulo - USP. Fonte: ZANCUL et al, 2014, Disciplina de formação para a inovação, com base em projeto multidisciplinar e prototipação de soluções complexas para problemas reais da sociedade. Apresentado no III Simposio Temático da Pró-reitoria de graduação - A docência na USP: Desafios e Inovações.

${ }^{2}$ Alunos de graduação dos cursos de Nutrição, Sistemas de Informação, Arquitetura e Urbanismo, Engenharia Ambiental e Engenharia Civil.
} 
Figura 2: Identificação de fatores que interferem na qualidade do ar da região

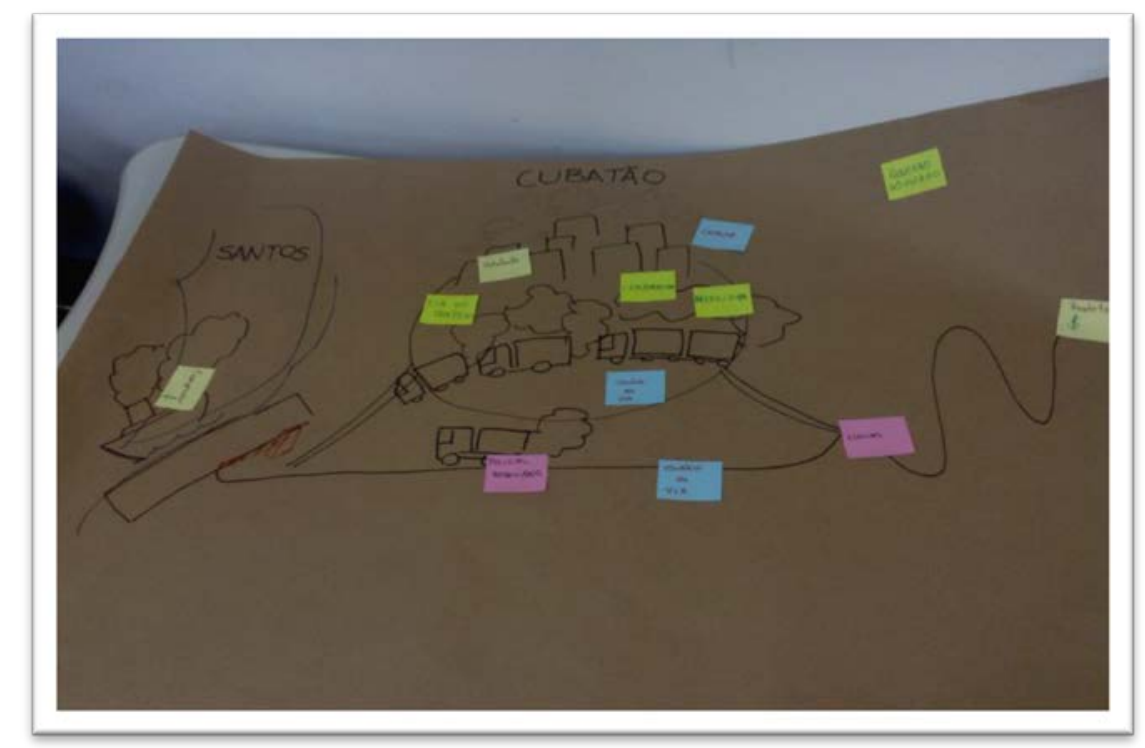

Fonte: FIGUEIREDO et al, 2014, p. 4

Em seguida, após entendimento dos fatores que interferem na qualidade do ar, foram evidenciados os agentes diretos e indiretos que se relacionam ao problema, organizados em dois grupos.

No primeiro grupo "estão os agentes que participam diretamente, vivendo no seu dia-adia a poluição do ar em Cubatão e/ou participando do seu aumento. Já no segundo grupo, estão as organizações que participam do problema de maneira mais administrativa, monitorando vias, fazendo medições da qualidade do ar e implementando projetos com a finalidade de tentar controlar a situação” (FIGUEIREDO et al, 2014, p.5). Além dos clientes identificados em Cubatão, face à natureza do problema, outros clientes surgiram, como os caminhoneiros e os produtores, que são oriundos de outras regiões do Estado de São Paulo ou de outros Estados do Brasil.

Com base nesta divisão, foi feita uma avaliação de forma a considerar a relação destes grupos com a poluição e o congestionamento, utilizando como marcadores números e cores, segundo sua relação a problemas ambientais. Desta forma, concluíram que o persona relacionado a esse problema seria "alguém capaz de receber as informações de cada organização, integrar esses dados e gerar uma política pública que pudesse trazer alguma mudança. Foi criado então o persona com o cargo de Gestor Otimizador da Qualidade do Ar” (FIGUEIREDO et al, 2014, p. 5).

O persona foi delineado como um homem de 40 anos chamado Roberto, usuário do projeto, que trabalha no setor público e possui influência política. Com base nesta definição, seguiu-se etapa de levantamento de suas necessidades - user needs (Figura 3). 
Figura 3: Necessidades do persona - Gestor otimizador da qualidade do Ar

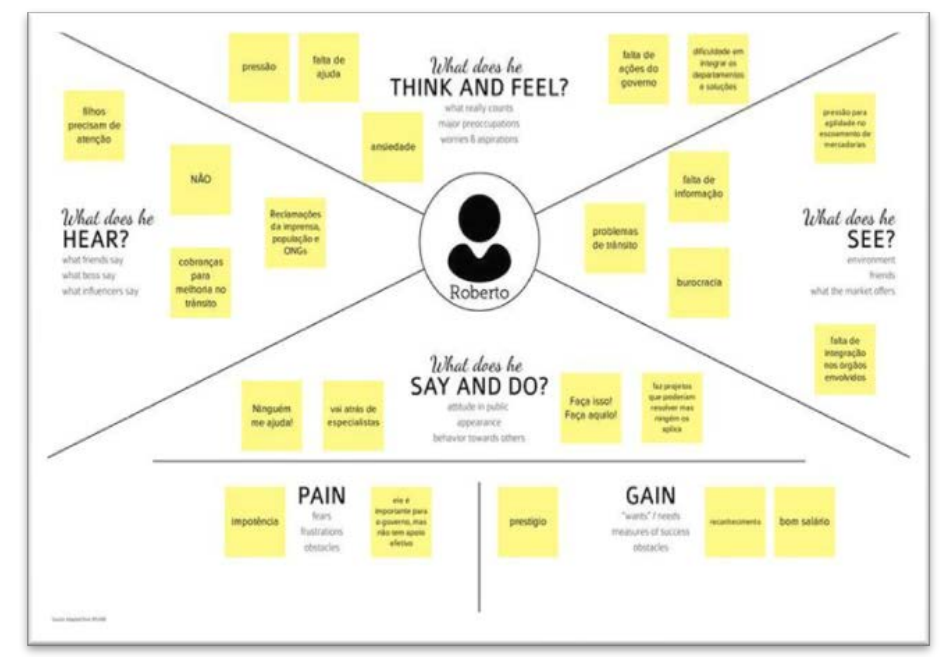

Fonte: FIGUEIREDO et al, 2014, p. 8

Em sequência foram identificados alguns modelos de benchmarking existentes para sistemas diversos: i) sistemas de gerenciamento de enchentes, ii) modelo logístico de ambulâncias, iii) modelos de instalação de equipamentos para monitoramento de emissões (Environmental Pollution Data - EPD) e iv) Gestão dos Aeroportos para a Copa do Mundo de 2014 (FIGUEIREDO et al, 2014). Nesta fase de avaliação dos sistemas identificados, foram destacadas as características que poderiam ser utilizadas para o desenvolvimento de uma solução para o problema apresentado.

Em seguida as ideias foram categorizadas em: produtores, porto, gerenciamento, modais e Cubatão (Figura 4) para ideação.

Figura 4: Categorização de ideias

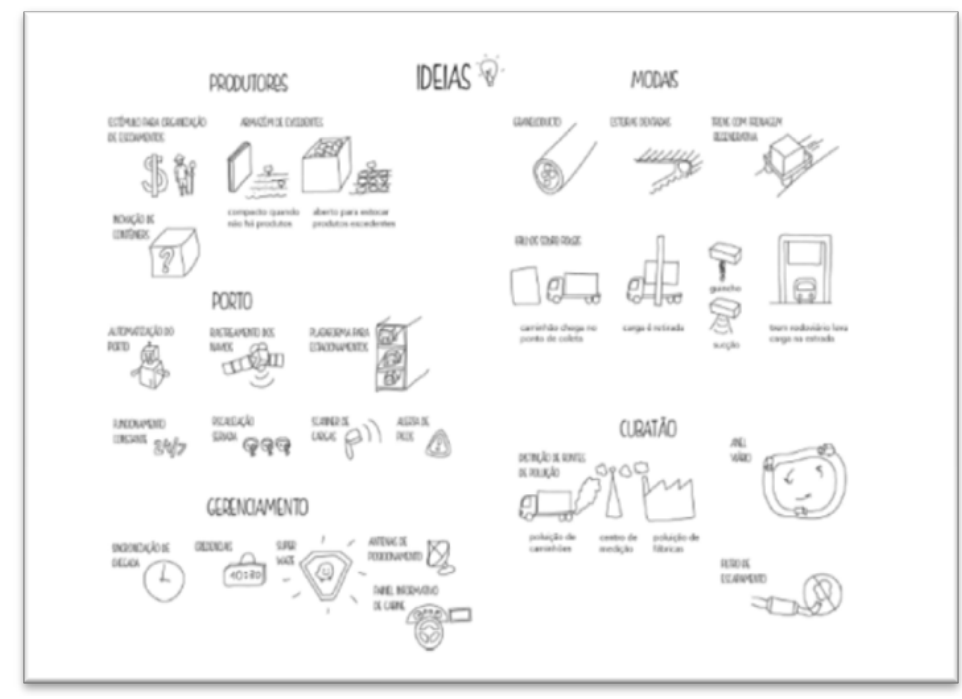

Fonte: FIGUEIREDO et al, 2014, p. 19 
Nas próximas etapas, foram realizadas diversas entrevistas e visita técnica às instalações do Porto de Santos, conhecendo-se o padrão de funcionamento dos terminais da margem direita, com foco sobre os procedimentos de importação. Conforme Figueiredo et al (2014), no levantamento feito constatou-se que o agronegócio brasileiro é uma das fontes de geração de renda mais importantes para o País, sendo responsável, em 2013, por 22,5\% do Produto Interno Bruto (PIB).

Além disso, observa-se crescente aumento das exportações de grãos, especialmente soja, a partir de 1995, e milho, a partir de 2005 (Figura 5).

Figura 5: Evolução das exportações de grãos pelo Porto de Santos até 2013

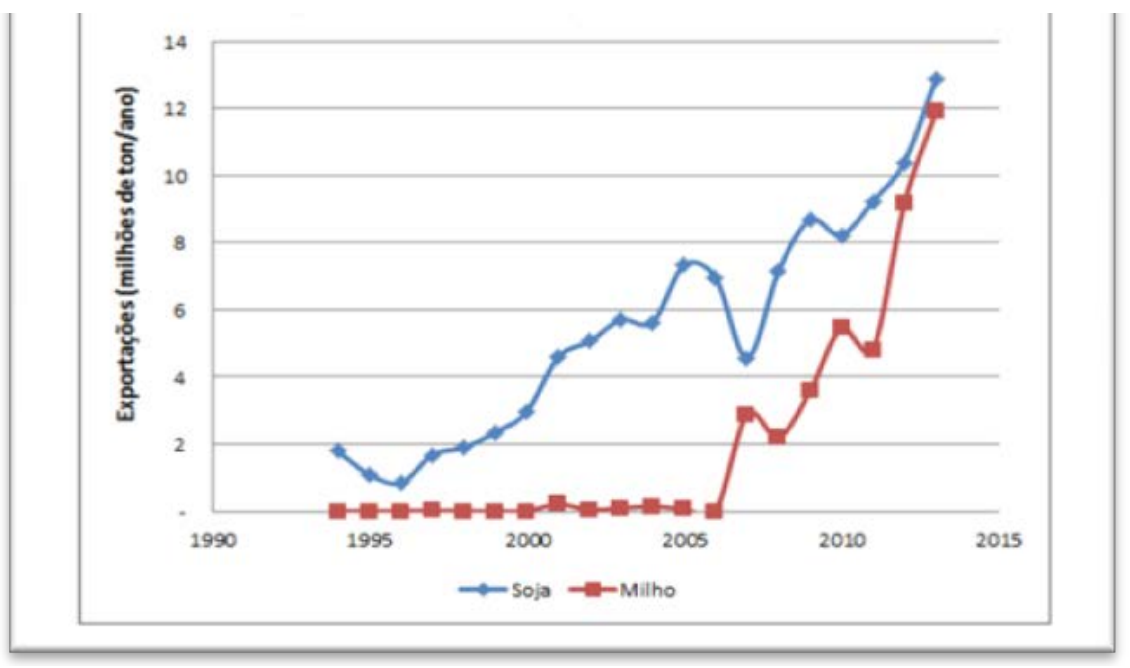

Fonte: ANEC - Associação Nacional dos Exportadores de Cereais citada por FIGUEIREDO et al, 2014, p. 29

Também, verifica-se que as exportações de grãos estão sujeitas às safras, sendo que as principais safras exportadas se intercalam durante o ano (Figura 6). Observa-se que praticamente durante o ano todo, há períodos de intensa movimentação no Porto de Santos, devido à exportação de grãos. 
Figura 6: Sazonalidade das exportações pelo Porto de Santos - 2013

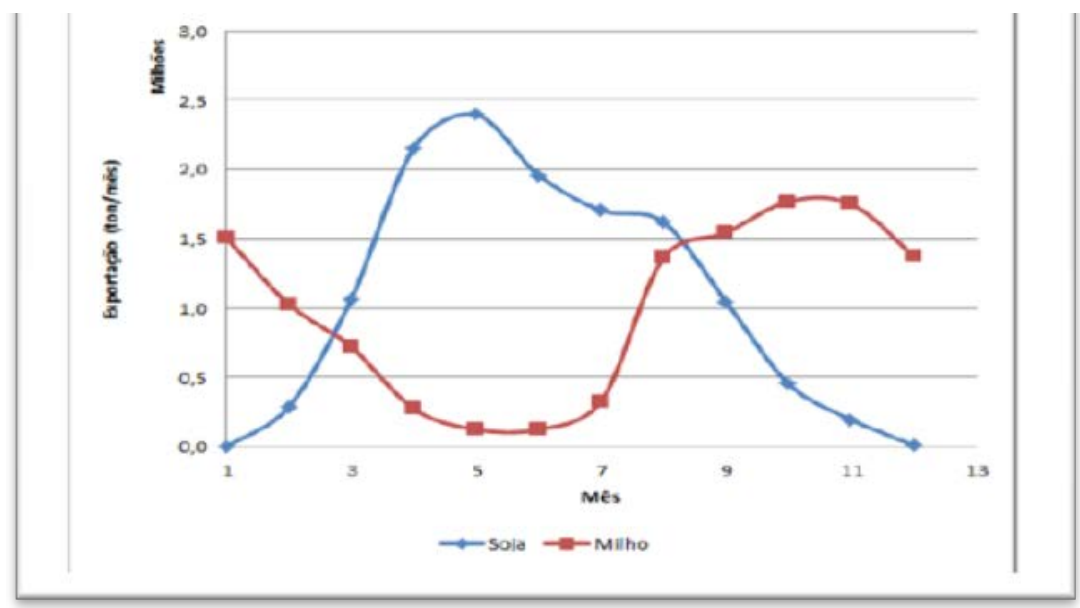

Fonte: ANEC - Associação Nacional dos Exportadores de Cereais citada por FIGUEIREDO et al, 2014, p. 29

Continuando a fase de ideação, foram apresentadas propostas para os modais que poderiam ser utilizados ou melhorados para promover o transporte de cargas.

Um dos sistemas analisados para o transporte de cargas envolveria a criação de um aplicativo denominado "Super Waze" (nome fantasia), que seria um sistema de informações de posição e velocidade médias coletadas por meio de aplicativos com informações GPS, informando e orientando o caminhoneiro para descansar ou realizar paradas para acertar o agendamento para realizar a carga ou descarga no Terminal Portuário (Figura 7).

Figura 7: Representação do "Super Waze"

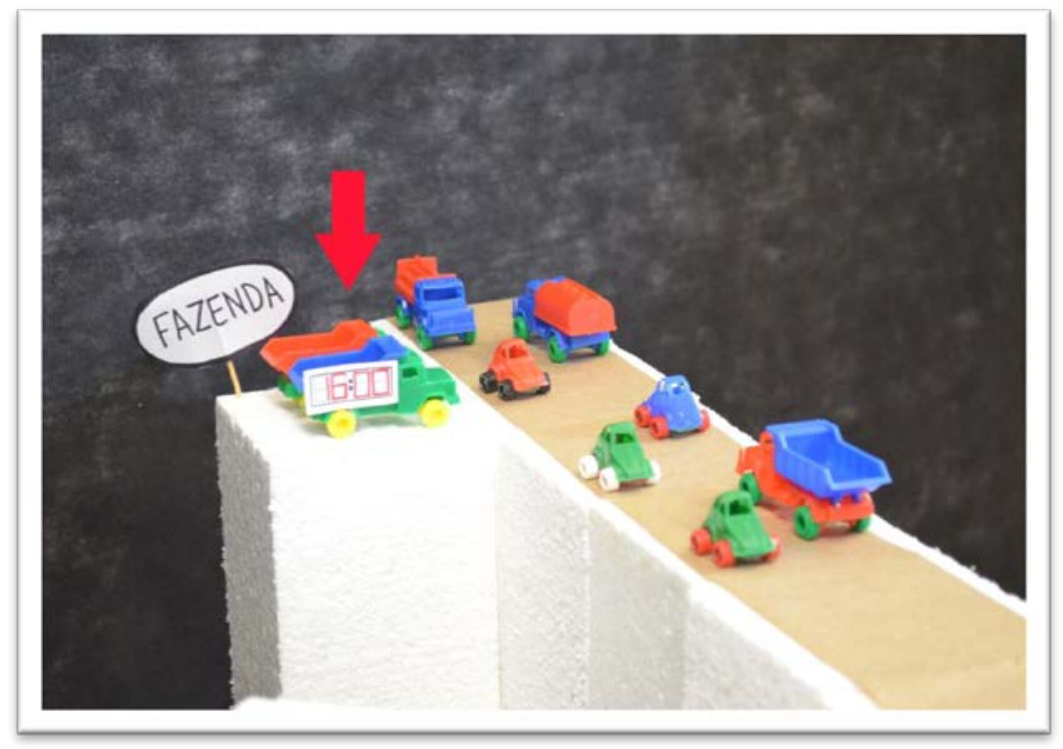

Fonte: FIGUEIREDO et al, 2014, p. 27 
Em seguida foi estabelecido um protótipo do tipo dark horse. O termo dark horse constitui uma das etapas do método de design thinking, sendo uma metáfora dos eventos de corridas de cavalos, em que a maioria das pessoas não apostaria nada em um cavalo "azarão" que, ao final, caso ganhe a corrida, representa grande ganho (inovação). Antes do desenvolvimento do protótipo dark horse foi feito um reenquadramento dos antigos pressupostos.

Iniciou-se o protótipo, que poderia, ou não, tornar-se o protótipo final (Figura 8). Considerando o baixo consumo de energia e não emissão de poluentes no local de estudo, o transporte de grãos, por meio de dutos, principalmente para a soja, se mostrou uma ótima saída para o problema em Cubatão, já que tiraria das estradas vários veículos. Para tornar a ideia possível, o duto foi planejado para fazer somente o percurso de descida da serra, sendo que a carga seria recebida no alto da serra por um terminal, desceria pela ação da gravidade e seria distribuída na Baixada por esteiras fechadas até o terminal de destino.

Figura 8: Prototipagem do dark horse

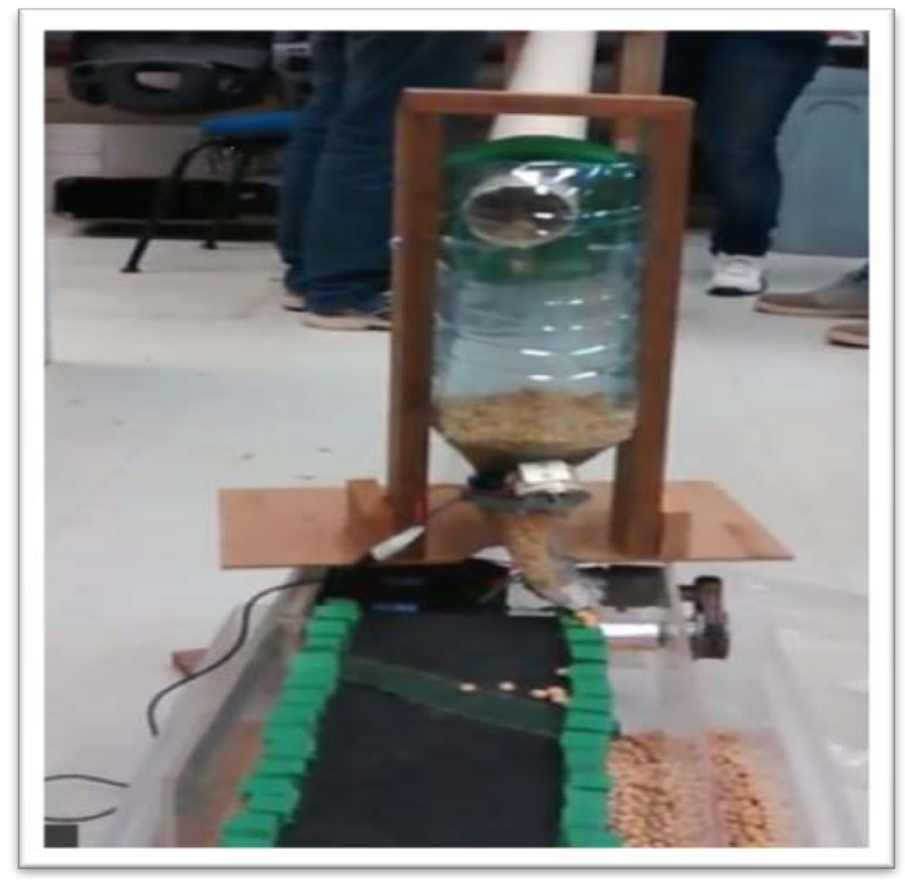

Fonte: Demonstração física do projeto, FIGUEIREDO et al, 2014, p. 32

\section{Etapa 5: Conclusões e recomendações}

Nas conclusões e recomendações, foram consideradas todas as etapas desenvolvidas nesta pesquisa. Buscou-se realizar uma análise geral dos cenários, das ações que foram positivas para equacionar uma situação crítica de poluição no Município de Cubatão, dos objetivos e hipóteses apresentadas nesta pesquisa e da proposta de solução conceitual tecnológica apresentada. 


\section{CAPÍTULO 2 - REVISÃO BIBLIOGRÁFICA}

\subsection{Município de Cubatão e entorno}

\subsubsection{Localização geográfica}

O Município de Cubatão ocupa uma área de $148 \mathrm{~km}^{2}$ e situa-se a $57 \mathrm{~km}$ da Capital paulista. A altitude máxima é atingida na Serra do Mar, com 700 metros. A região é formada por área serrana, compreendendo escarpas e áreas de planícies. Na área, com o nome local de Serra de Cubatão, a serra se desdobra em patamares inferiores, isolados do bloco principal pelos vales dos rios Cubatão e Mogi (PREFEITURA MUNICIPAL DE CUBATÃO, 2014a). A figura 09 apresenta imagem com a localização de Cubatão com destaque do Polo Industrial abrigado entre as escarpas da Serra do Mar.

Figura 09: Baixada Santista, assinalado o Município de Cubatão e o Polo Industrial.

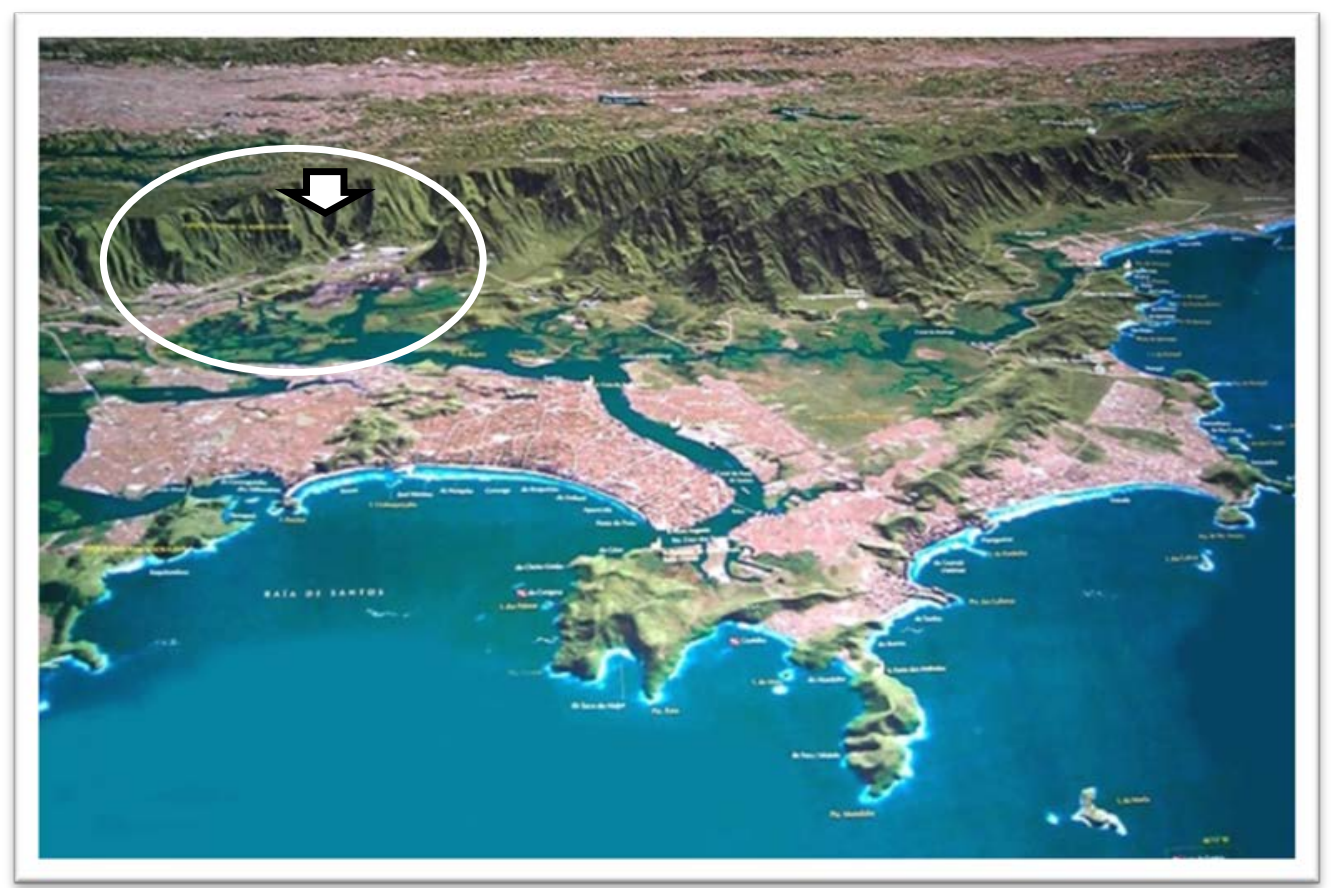

Fonte: Secretaria da Habitação/Secretaria de Meio Ambiente - Projeto de desenvolvimento sustentável do Litoral Paulista, ano 2013 (modificado)

\subsubsection{Desenvolvimento econômico e mudanças na dinâmica da região}

Para compreender as alterações ocorridas do município de Cubatão, é necessário conhecer o desenvolvimento econômico e consequências na região. Foram identificadas as principais vocações ao longo do tempo e os fatos considerados marcantes para fins desta pesquisa. 


\section{- Colonização}

Cubatão iniciou sua história caracterizando-se essencialmente como um lugar de passagem, obtendo assim um papel de destaque no cenário regional e nacional. Esta vocação foi sendo desenhada já desde a época dos jesuítas e tropeiros que lá paravam antes de atingir o Planalto (PREFEITURA MUNICIPAL DE CUBATÃO, 2014b).

\section{- Século XVIII até meados do século XIX}

Da primeira metade do século XVIII até a segunda metade do século XIX a subsistência de Cubatão estava centrada em sua função portuária. O Porto Geral de Cubatão era a única ligação entre a Baixada e o Planalto Paulistano. Neste porto, as cargas e mercadorias trocavam as balsas que vinham do Porto de Santos pelo lombo das mulas e formavam as tropas que subiam a Serra do Mar. Com estas atividades, foi-se formando, nas proximidades do Porto, um povoado que posteriormente se tornou um município (FERREIRA, 2007; PREFEITURA MUNICIPAL DE CUBATÃO, 2014c).

A primeira alteração da dinâmica do Município ocorreu com a construção da Estrada de Ferro Santos-Jundiaí, em 1867, fazendo com que a função portuária entrasse em declínio, uma vez que a ferrovia passou a absorver grande parte do transporte de produtos. Para a sobrevivência da região, a alternativa viável, foi a agricultura, tendo no cultivo da banana o produto de grande expressão econômica para a cidade, ao lado da atividade de extração de areia e pedras. Já se identificava também uma primeira fase de industrialização, com a instalação de curtumes no final do século XIX e, em 1916, da Cia. Anilinas de Productos Chímicos do Brasil, localizada no centro da cidade (FERREIRA, 2007; PREFEITURA MUNICIPAL DE CUBATÃO, 2014c). Porém, mesmo com estas atividades que apresentaram mudanças na vocação econômica, Cubatão não sofreu grandes alterações em relação às atividades desenvolvidas e a compatibilidade com os recursos e espaços disponíveis.

\section{- Meados do século XIX até 1920}

Em meados do século XIX até a década de 1920, quando surgiram as obras da Light e da Companhia Santista de Papel, o cenário começou a se alterar. A instalação destas duas empresas foi um marco significativo e levou a uma alteração da dinâmica na região, já sinalizando novas tendências de ocupação e oportunidades de crescimento econômico com o fornecimento de energia, atraindo pessoas de outras localidades, criando as vilas operárias e o planejamento de desenvolvimento da região (FERREIRA, 2007; PREFEITURA MUNICIPAL DE CUBATÃO, 2014c).

Dessa primeira fase industrial, a de maior expressão econômica foi a Cia. Santista de Papel S.A., construída ao pé da Serra, em 1918 (...) Sua 
localização (...) foi devida à proximidade com o porto de onde receberia matéria-prima $e$ aproveitamento das cachoeiras para obtenção de energia. Essa companhia trouxe certo dinamismo para a região devido à atração de forasteiros, o que resultou no incremento comercial e, durante 30 anos, foi a grande fábrica de Cubatão, sendo conhecida como Companhia Fabril de Cubatão (PREFEITURA MUNICIPAL DE CUBATÃO, 2014c).

A denominação "Fabril" passou a ser atribuída devido a ser o único bairro onde existia fábrica (...) a indústria contava com fontes de captação $e$ tratamento próprio no Rio Cubatão. Em iniciativa arrojada para a época, a indústria construiu em terreno próprio uma vila operária com mais de uma centena de casas (PREFEITURA MUNICIPAL DE CUBATÃO, 2014c).

Um marco significativo para o município foi a construção da Usina Henry Borden pela São Paulo Light S.A. Serviços de Eletricidade, hoje Empresa Metropolitana de Água e Energia (EMAE). Longe de ser ocasional, a instalação da usina foi ditada por fatores físicos para aproveitamento das escarpas da serra na produção de energia ...) (PREFEITURA MUNICIPAL DE CUBATÃO, 2014c).

\section{- $\quad$ Período de 1921 a 1950}

Quando Getúlio Vargas estava no governo, após a Revolução de 1932, a economia estava marcada pela crise mundial de 1929. A economia brasileira estava muito vulnerável, pois dependia totalmente do mercado externo do café, chamando a atenção para a necessidade de adaptação à nova realidade internacional, o que levou o país a buscar a industrialização. A implantação do Estado Novo, em 1937, acentuou o intervencionismo. Para promover o reaparelhamento das Forças Armadas e a implantação de um vasto programa de obras públicas, a siderurgia tornava-se um fator central e indispensável. A industrialização teve início em 1946, com a criação da Companhia Siderúrgica Nacional (CSN), em Volta Redonda (RJ) (MOREIRA, s/d). 


\section{- Período de 1951 a 1980}

Como desdobramento do início da industrialização no País, o período de 1951 a 1980 foi de suma importância para a história de Cubatão. Desta forma, identificou-se a necessidade de retratar o momento político destas décadas, que levou a diretrizes que influenciaram de forma intensa no desenvolvimento de Cubatão e as suas consequências.

\section{$\checkmark$ Década de 1950}

Em 1953 foi implantada a segunda pista da Via Anchieta e os primeiros trechos da rodovia SP-55 (Rodovia Padre Manuel da Nóbrega) que estabelece ligação entre o litoral de São Paulo, e o Vale do Ribeira, onde termina no entroncamento com a Rodovia Régis Bittencourt (BR-116). A rodovia Padre Manuel da Nóbrega foi considerada a espinha dorsal da rede rodoviária litorânea (CIDE, 2006).

Em 1956, Juscelino Kubitschek apresentou o Plano de Metas, que tinha por objetivo transformar o Brasil em uma nação industrializada no menor tempo possível (“Cinquenta anos em cinco”). O Plano consistia em 31 metas divididas em 06 categorias: energia, transporte, alimentação, indústrias de base, educação e a construção de uma nova capital no Planalto Central (Brasília). Com isso, Cubatão passou a ser citada no Plano de Metas, para as categorias: energia elétrica, petróleo, petroquímica, fertilizantes e siderurgia, sendo neste período que foram implantadas as indústrias em Cubatão (VALARINI, 2011).

\section{$\checkmark$ Década de 1960}

Na década de 1960, em continuação ao Estuário de Santos, foi constituído o Canal de Piaçaguera com acesso aos Terminais Marítimos Privativos da COSIPA (atual USIMINAS) e da Ultrafertil (Atual VLI). O canal é responsável pelo acesso de 40 navios por mês aos terminais ao Polo Industrial de Cubatão (CIDE, 2006).

Em 31 de março de 1964, um golpe militar foi deflagrado contra o governo de João Goulart. No dia 2 de abril, foi organizado o "Comando Supremo da Revolução” Os militares envolvidos no golpe de 1964 justificaram sua ação afirmando que o objetivo era restaurar a disciplina e a hierarquia nas Forças Armadas e deter a "ameaça comunista" que, segundo eles, pairava sobre o Brasil. Uma ideia fundamental era que a principal ameaça à segurança do país não viria de fora, mas de dentro do próprio país, através de brasileiros que atuariam como "inimigos internos" (expressão da época). Essa visão estava na base da chamada "Doutrina de Segurança Nacional". Com o golpe, deuse início a um regime político marcado pelo "autoritarismo", privilegiando a autoridade do Estado em relação às liberdades individuais (CASTRO, s/d).

O Ato Institucional $n^{\circ} 5$ (AI-5), baixado em 13 de dezembro de 1968, durante o governo do general Costa e Silva, vigorou até dezembro de 1978. O AI-5 autorizava o presidente 
da República, em caráter excepcional e, portanto, sem apreciação judicial, a: decretar o recesso do Congresso Nacional; intervir nos estados e municípios; cassar mandatos parlamentares; suspender, por dez anos, os direitos políticos de qualquer cidadão; decretar o confisco de bens considerados ilícitos; e suspender a garantia do habeascorpus (D'ARAUJO, s/d).

Este cenário foi importante para Cubatão, para compreender o estágio de degradação ambiental que foi instaurado, com a imposição do governo sobre a atuação da produção das empresas ali instaladas.

A partir de 1961 começaram a surgir as primeiras reclamações vindas dos municípios de Santos e São Vicente (1963) acerca da poluição atmosférica. Foram registrados no pronto-socorro dez casos de intoxicação por poluentes (1968), levando a, em 1970, iniciarem-se os contatos entre prefeitura e as indústrias visando a redução das emissões. Em 1970 a prefeitura de Cubatão realizou o "I Seminário de Poluição do Ar e das Águas da Baixada Santista” para discutir os problemas e propor soluções. Em 1972, ocorreu o “II Seminário de Poluição do Ar e das Águas da Baixada Santista”, em que se buscaram ações mais práticas.

\section{$\checkmark$ Década de 1970}

A crise internacional do petróleo desencadeada em 1973 afetou o desenvolvimento industrial e aumentou o desemprego. Diante desse quadro, o então presidente da República, General Ernesto Geisel (1974-1979) propôs um Plano Econômico denominado “II Plano Nacional de Desenvolvimento” (PND II). Este plano tinha como finalidade estimular a produção de insumos básicos como bens de capital, alimentos e energia. Este plano foi uma resposta à crise econômica decorrente da crise do petróleo, no fim do chamado "milagre econômico brasileiro". Foi o último grande plano econômico do ciclo desenvolvimentista e provavelmente, o mais amplo programa de intervenção estatal na economia do país (MANTEGA, 1997 apud II PLANO NACIONAL DE DESENVOLVIMENTO, 2012).

Nesta época, o Brasil era altamente dependente do petróleo. Cerca de $80 \%$ do petróleo consumido provinha de importações. Uma das diretrizes propostas pelo PND II era a redução da dependência do petróleo árabe, por meio do investimento na exploração e refinamento de petróleo dentro do Brasil, e o investimento em fontes alternativas de energia, como o álcool e a energia nuclear. O PND II também investiu pesadamente na produção de insumos básicos e bens de capital (II PLANO NACIONAL DE DESENVOLVIMENTO, 2012).

Este ponto de vista foi observado também por Ferreira (2007), quando relata que o período de industrialização tinha por principal objetivo reforçar o potencial produtivo nacional, e inexistiam pressões políticas sobre restrições ambientais ou restrições internacionais, a financiamentos. Ainda conforme a autora, a evolução demográfica de Cubatão foi bastante acelerada a partir da industrialização e caracterizada pela intensa migração de trabalhadores, especialmente os oriundos da região Nordeste do País. 
Formaram-se então, ao lado dos canteiros de obras e, posteriormente, às fábricas, as vilas operárias, que, diferentemente das do início do século XX (Vila Fabril e Vila Light), não tinham a mesma estrutura, favorecendo a favelização. Após a instalação das unidades fabris, houve pouco aproveitamento da mão-de-obra pelas próprias indústrias, levando a um quadro de ocupação ilegal de terrenos pelos trabalhadores desempregados, como margens de rodovias e ferrovias e, áreas de preservação ambiental como as escarpas e mangues (FERREIRA, 2007).

Este baixo aproveitamento da mão-de-obra ocorreu em função do alto índice de mecanização das modernas fábricas, requerendo um número baixo de empregados se comparados ao volume de produção. Para trabalhar nas indústrias havia a necessidade de qualificação destes empregados, fato que também colaborou para o baixo aproveitamento da mão-de-obra (CIDE, 2006; FERREIRA, 2007). A Agenda 21 de Cubatão, de 2006, relata que:

A industrialização provocou uma forte corrente migratória para Cubatão. Havia muitos empregos com poucas exigências técnicas nas obras civis de instalação das indústrias. O quadro de uma população rural até então predominante, rapidamente se inverteu (CIDE, 2006, p.31)

Uma das consequências do subemprego foi o aumento da população que improvisava moradias em locais inadequados como as encostas da Serra do Mar e as regiões de mangue, num processo de ocupação desordenada que se estende aos dias de hoje (CIDE, 2006, p. 31)

A falta de mão-de-obra qualificada levou à busca de empregados nas demais cidades da Baixada Santista e da Região Metropolitana de São Paulo - RMSP (CIDE, 2006).

A instalação das indústrias ocorreu sem planejamento, de forma desordenada, de acordo com as necessidades de cada empresa e recursos disponíveis na região. Destaca-se que o processo de industrialização de Cubatão não tomou como base o núcleo urbano preexistente, dificultando a integração das indústrias com este núcleo, levando a um desenvolvimento do município à parte do desenvolvimento do Polo Industrial (FERREIRA, 2007).

Analisando a década em questão, identifica-se que o Município não estava preparado com a infraestrutura necessária, como escolas e hospitais, para a explosão demográfica que se seguiu à industrialização conforme descrito no relatório da Agenda 21 de Cubatão, de 2006 (CIDE, 2006). 
Por outro lado, os trabalhadores mais qualificados, oriundos dos municípios vizinhos, também passaram a se deslocar diariamente a Cubatão, que se tornou uma importante base econômica para outras cidades da região (CIDE, 2006, p.31).

Houve aumento de deslocamento dos empregados que residiam nos demais municípios da Região Metropolitana da Baixada Santista (RMBS) e RMSP, concorrendo com o fluxo de caminhões. Os benefícios advindos da renda gerada pela indústria, não ficaram concentrados no Município. O comércio, por exemplo, ficou centralizado principalmente nos municípios de Santos e São Vicente, cabendo a Cubatão conviver com os problemas com a ocupação desordenada, a favelização e o subemprego.

Em 1973, face às pressões internas e externas, o Governo Federal criou a Secretaria Especial de Meio Ambiente - SEMA (LEMOS, 1995, citado por FERREIRA, 2007, p. 136). Neste mesmo ano, foi constituída no Estado de São Paulo, a Companhia de Tecnologia de Saneamento Básico e de Controle da Poluição das Águas - CETESB, por meio da Lei Estadual $n^{0}$ 118, de 29 de junho de 1973, que dentre suas atribuições, compete-lhe a de fiscalizar e impor penalidades a quem cause poluição ou degradação do meio ambiente.

Porém, mesmo com as reclamações e o quadro de poluição no Município, não havia abertura para que ações rigorosas fossem adotadas, conforme Couto (2003), citado por Valarini (2011, p.12), “[...] a industrialização brasileira foi tratada pelo Estado como interesse nacional a qualquer custo. Em 1975, o então presidente da república, General Ernesto Geisel, retirou dos municípios o direito de fechar suas indústrias poluidoras”.

Conforme Ferreira (2007, p. 123), a impotência dos órgãos ambientais frente à situação política da época fica clara para a realidade de Cubatão “[...] as questões de infraestrutura de transportes e energia, o equacionamento dos problemas das indústrias siderúrgicas e petrolífera e a instalação de novos setores industriais adquiriram foros de problemas nacionais, prioritários e intangíveis, tanto que o complexo industrial de Cubatão contou sempre com a capa protetora dos Órgãos de Segurança Nacional”.

O quadro de poluição em Cubatão foi se agravando (Figura 10) até que, em 1975, a ocorrência de duas mortes devido à intoxicação pelo "pó da China” foi o estopim para proposição de ações. 
Figura 10: Polo Industrial - década de 1970

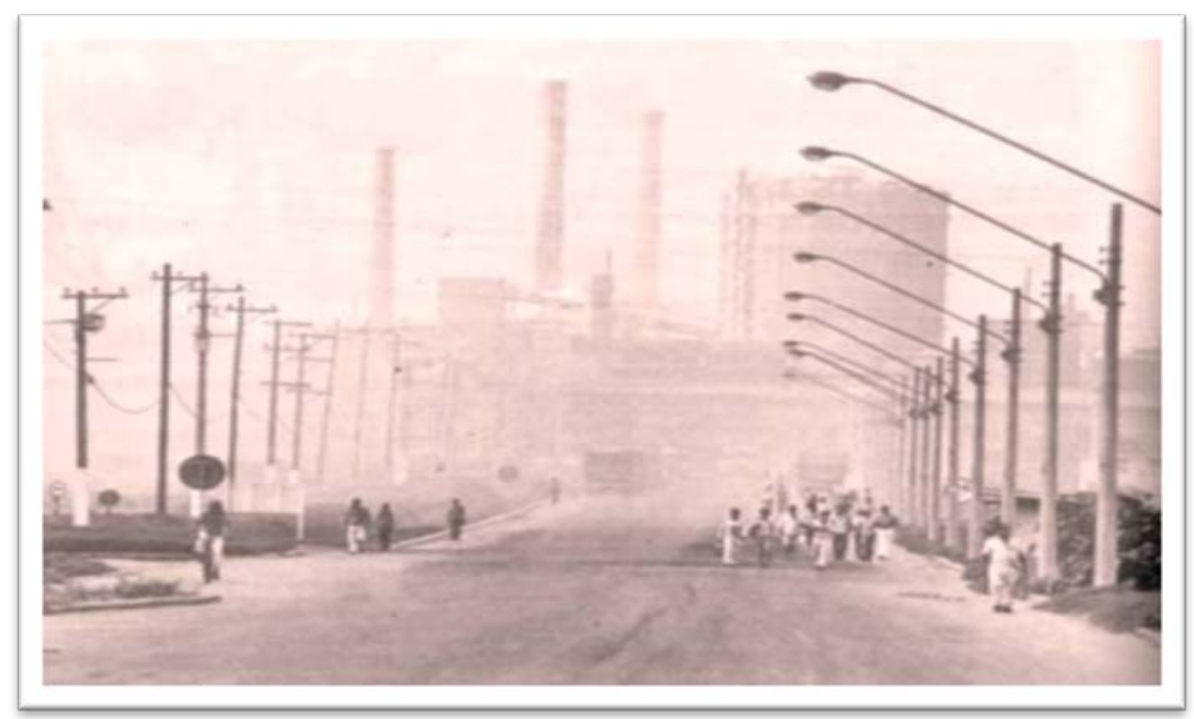

Fonte: Novo Milênio, 2014

Para reforçar a atuação da CETESB no controle da poluição no Estado de São Paulo, o Governo do Estado publicou em 08 de setembro de 1976, a Lei 997 e o Decreto Estadual 8.468, que a regulamenta. O Decreto Estadual 8.468 estabelece em seu artigo $6^{\circ}$, as atribuições da CETESB, para prevenção e controle da poluição. Entre essas atribuições estão o estabelecimento e execução de planos e programas de atividades de prevenção e controle da poluição, efetuar o levantamento organizado e manter o cadastro das fontes de poluição e, inventariar as fontes prioritárias - fixas e móveis - de poluição.

Neste decreto estadual foram definidos padrões de qualidade do ar, das águas, regras de licenciamento ambiental de novas unidades industriais, gestão de resíduos, sanções e penalidades. Este documento legal foi a "mola propulsora” para ações de gestão de controle da poluição em Cubatão.

O Decreto 8.468, também instituiu a “Operação Inverno” em áreas saturadas para um determinado parâmetro de qualidade ambiental. À época, a Operação Inverno se aplicava à RMSP e Cubatão, que eram consideradas saturadas para o parâmetro material particulado $\left(\mathrm{MP}_{10}\right)$. A Operação Inverno consiste num plano de ações de controle de poluição atmosférica, previsto para ser implantado quando os índices de qualidade do ar representarem condições impróprias e com risco à saúde da população exposta.

Nesta década, as diretrizes de desenvolvimento ditadas pelo Governo Federal, trouxeram consequências significativas para Cubatão, para os segmentos social e econômico, ficando clara a alteração da dinâmica de ocupação da região, sobrecarregando o Município.

Porém foi nas questões ambientais, que estas afetaram significativamente o Município. As diretrizes de desenvolvimento implantadas à época trouxeram como consequência o 
caos ambiental, tornando Cubatão a referência negativa de industrialização e desenvolvimento, em nível mundial.

\section{- Período de 1981 a 1990}

A década de 1980 foi um período em que o mundo passava por crises e instaurou-se uma recessão em que os gastos públicos eram contidos e as importações estavam restritas. No governo do então presidente João Baptista Figueiredo (1979 - 1985), o ministro Delfin Netto, do Planejamento, defendia uma política econômica baseada no crescimento a qualquer custo, tendo em vista um rápido desenvolvimento da economia no país, buscando um novo "milagre econômico". Mas com a situação externa desfavorável e um segundo choque do petróleo e a alta dos juros externos, os investimentos almejados não puderam ser realizados, pois dependiam de financiamento estrangeiro. Este período ficou conhecido como a "década perdida", e foi caracterizada pela queda nos investimentos e no crescimento do Produto Interno Bruto (PIB), pelo aumento do déficit publico, pelo crescimento da dívida externa e interna e pela ascensão inflacionária (RODRIGUES, 2005).

Com a crise econômica instaurada a partir do início da década de 1980, e a deterioração das contas públicas, houve um abandono de políticas setoriais também na área de infraestutura de transportes. De acordo com Figueiredo et al (2014, pp.29 e 30), o escoamento da soja do Centro-Oeste teve perdas significativas por dispor apenas do modal rodoviário.

Esta crise afetou diretamente as indústrias de Cubatão. A falta de investimentos e restrição de importação de matérias-primas levou a uma escalada do "sucateamento" das empresas estatais que, na sua maioria, compunham o Polo industrial de Cubatão.

Com o cenário crítico de poluição instaurado em Cubatão, a pressão da sociedade para a adoção de ações imediatas foi premente. As mudanças significativas começaram a ocorrer quando o então governador, André Franco Montoro, estabeleceu diretrizes de proteção ambiental, com a implantação de um plano de longo prazo para o controle da poluição do ar no Estado de São Paulo. Para Cubatão, em caráter prioritário, foram implantadas medidas imediatas e emergenciais, tendo sido estabelecido o "Plano de Ação de Controle de Poluição de Cubatão”, em 1983 (FERREIRA, 2007).

As ações de gestão componentes do Plano de Ação de Controle de Poluição Ambiental em Cubatão tiveram como objetivo, adotar ações corretivas visando a redução das emissões de poluentes atmosféricos e de outros poluentes das fontes existentes no Polo Industrial de Cubatão, basicamente sobre as fontes fixas, e adotar medidas preventivas como a proibição de implantação de novas fontes de poluição e aumento de produção ou alteração de processos produtivos que possam acarretar aumento das emissões atmosféricas (FERREIRA, 2007).

Para implantação do Plano de Ação de Controle de Poluição Ambiental em Cubatão, foi necessário inicialmente realizar o inventário das indústrias do Município para priorizar as ações de controle e padrões de emissão a serem adotados para cada tipo de indústria. 
Assim, foram examinadas e consideradas as condições locais e informações históricas relevantes sobre as características nativas da região. Entre 1983 e 1984 foi realizado o inventário, sendo registradas em Cubatão, 21 indústrias prioritárias para compor o Plano de Ação de Controle de Poluição em Cubatão. (CETESB, 1985a ${ }^{8}$ ).

Figura 11: Polo Industrial - início do inventário das fontes de emissão atmosférica

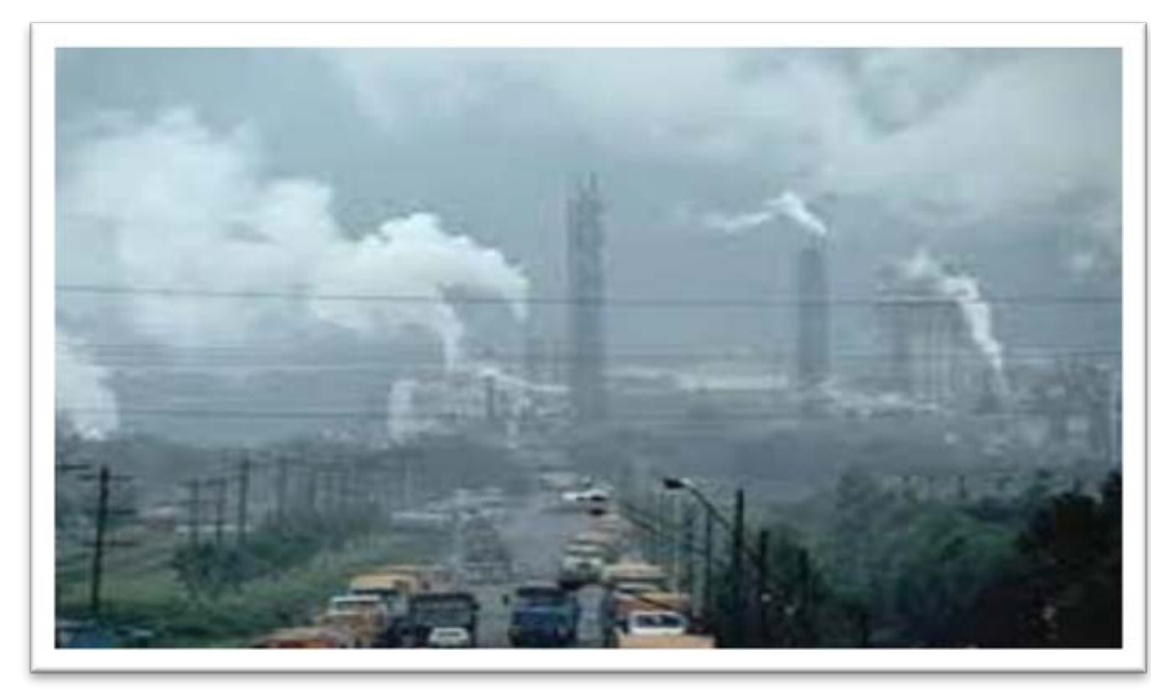

Fonte: Novo Milênio, 2014

As fontes fixas com necessidade de controle das emissões tiveram que apresentar o plano de melhoria tecnológica para aprovação da CETESB, e efetivar a sua implantação. Aliado a este plano de melhoria tecnológica, também foi importante a obrigatoriedade de registro de todas as empresas já instaladas em Cubatão, com o estabelecimento de exigências para controle das emissões. Como ações preventivas, foi instituído o licenciamento prévio à instalação de novas empresas, novos processos e ampliação de processos já existentes, que teve por finalidade evitar o aumento de poluição potencial (CETESB, 1985a ${ }^{8}$ ).

Na década de 1980, foram instaladas estações medidoras de qualidade do ar em Cubatão, que teve sua rede concebida de forma a considerar as concentrações representativas das áreas de maior densidade populacional, o impacto ao meio ambiente devido a determinadas fontes ou grupo de fontes e os níveis médios de concentração de poluentes na atmosfera para a região (CETESB, $2013 \mathrm{~d}$ ).

A CETESB vem operando uma rede automática de monitoramento da qualidade do ar desde 1981 e uma rede manual que mede os teores de enxofre/fumaça desde 1973, monóxido de carbono desde 1976 e partículas em suspensão desde 1983 (CETESB, 1985a ${ }^{8}$, p. 29).

Em Cubatão, foram instaladas inicialmente 03 estações medidoras (V. Nova, Vila Parisi e Centro). Em 1996, a estação de Vila Nova foi desativada. Em 2005 foi instalada a estação medidora do Vale do Mogi. Sendo assim, atualmente, Cubatão conta com uma 
rede de monitoramento composta por 03 estações medidoras de qualidade do ar (Vila Parisi, Cubatão-Centro e Vale do Mogi).

De acordo com Ferreira (2007), foi apresentado, em 1982, pela Comissão Interministerial, um levantamento das possíveis contribuições das fontes móveis no Polo Industrial, observando-se que o trânsito urbano de Cubatão era quase nulo, mas o trânsito nas rodovias era intenso, uma vez que o Município servia de passagem das principais vias de interligação entre o Planalto e a Baixada Santista e Litoral Norte. Observou-se que, neste momento, foi identificada a mudança do cenário em Cubatão, e se iniciaram as discussões com as possíveis contribuições das emissões de outras fontes, que não somente as fixas.

Em 1987, por meio do Decreto Estadual no 26.942, de 01 de abril de 1987, a CETESB passou a vincular-se à Secretaria de Estado do Meio Ambiente.

\section{- Período de 1991 a 2000}

No Brasil, a década de 1990 foi marcada pelo início do processo de privatização das empresas e serviços públicos, levando a questionamentos quanto à participação de capital estrangeiro em empresas estratégicas para o País.

Segundo Anuatti-Neto et al (2005), entre 1991 e 2001, o governo brasileiro transferiu ao setor privado o controle de mais de cem empresas estatais que geraram US\$ 67,9 bilhões em receitas, mais US\$18,1 bilhões em dívidas transferidas aos compradores, constituindo um dos maiores programas de privatização do mundo. Ainda conforme os autores, a privatização aumentou a lucratividade e a eficiência operacional das empresas. Em termos financeiros, a perda do suporte do governo para financiamentos diretos, forçou as empresas a uma reestruturação por meio da elevação da liquidez corrente e redução do endividamento de longo prazo.

Para Cubatão, o processo de privatização significou investimentos em equipamentos de controle ambiental, modernização das plantas e novas tecnologias de processo. Entendese que a privatização teve um papel importante para a mudança e reversão do quadro ambiental instalado.

Em comemoração aos 25 anos de implantação do Plano de Ação de Controle de Poluição de Cubatão, em 2008, a FIESP/CIESP apresentou os principais dados e resultados decorrentes dos investimentos e esforços já realizados para o controle da poluição de Cubatão. A Figura 12 apresenta os dados elaborados com base nos relatórios de qualidade do ar, emitidos pela $\mathrm{CETESB}^{3}$, considerando dados do período de 1983 a 2013.

\footnotetext{
3 Teve sua denominação novamente alterada para CETESB - Companhia Ambiental do Estado de São Paulo, pela Lei Estadual 13.542, de 08 de maio de 2009.
} 
Figura 12: Redução de emissões atmosféricas - 1983 a 2013

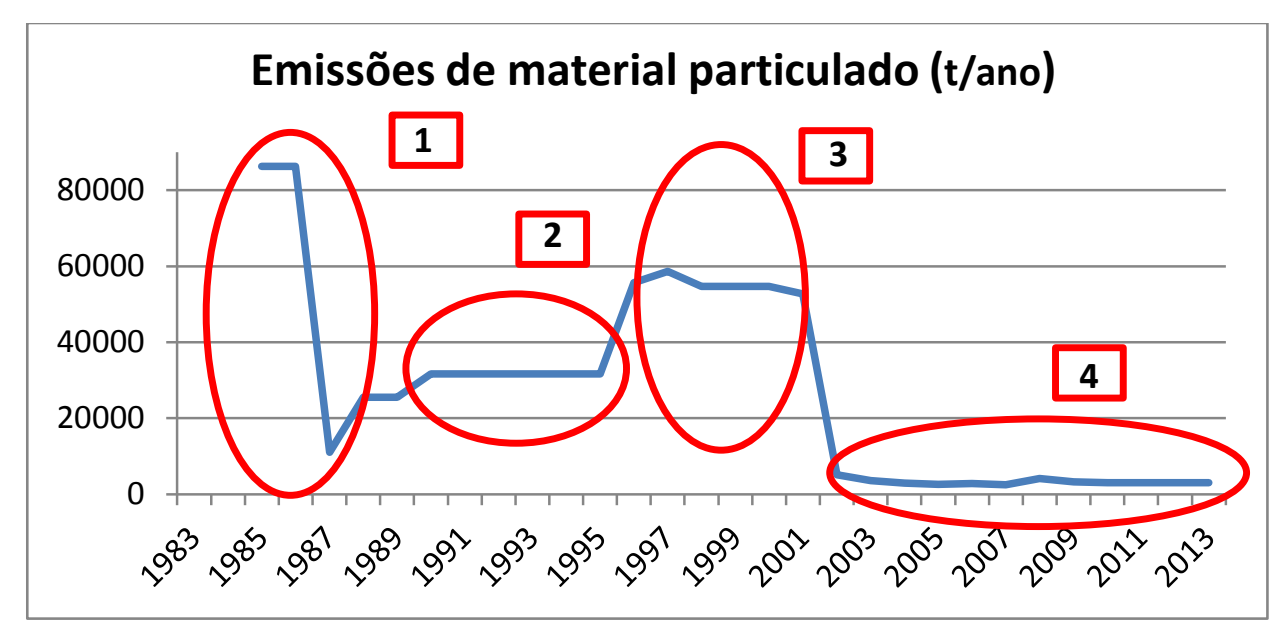

Fonte: Elaboração própria. Dados recuperados de relatórios de qualidade do ar CETESB série a, período 1985 a 2013

Observa-se no gráfico de emissões, variações significativas ao longo dos anos. Nos primeiros anos, os dados registrados para a primeira estimativa de emissão da região de Cubatão foram obtidos na época do Levantamento Industrial para cadastrar as fontes de poluição e implantação do Programa de Recuperação da Qualidade Ambiental de Cubatão, iniciado em 1984 (1). Após a classificação inicial, foram realizadas reuniões técnicas entre CETESB e as empresas da região para a discussão de temas como a tecnologia adequada para minimizar ou até mesmo cessar as emissões, os efeitos de cada agente poluidor, os prazos de implantação e os custos dos sistemas de controle. Com isso, observou-se que a estimativa de emissões das fontes estava superestimada. Em 1987 foi realizada uma correção, no entanto, esta nova estimativa ficou subestimada (1). Logo em seguida, foram realizados novos ajustes, como a elaboração de novo inventário de fontes de emissão em 1990 e a implantação de melhorias na sistemática da estimativa de emissões para o Polo de Cubatão, ficando portanto, definido o novo valor (aproximadamente de 31.000t/ano) que ficou mantido até 1996 (2).

A partir de 1997, foram identificadas mais algumas fontes de emissão que não foram consideradas na elaboração do inventário em 1990.

Assim a nova estimativa de emissão passou para cerca de 55.000 t/ano (3). Com o início da privatização (a partir de 1993) um amplo programa de modernização que envolveu a reforma/instalação de equipamentos de controle ou instalação de novas e mais modernas unidades industriais foi implantado no Polo Industrial de Cubatão. Após o fim do Programa de Modernização das empresas e a implantação do controle de emissões, a estimativa de emissão de material particulado caiu para 5.083,39 t/ano em 2002 e para 3.562,21 t/ano em 2004 (4), demonstrando eficiência de controle de aproximadamente 96\%, o que explica as variações no gráfico do inventário de emissões. 
O resultado desses esforços pode ser observado também, nos índices de qualidade do ar, registrados pelas estações medidoras em Cubatão (Figura 13).

Figura 13: Evolução das concentrações médias anuais $\left(M P_{10}\right)$, em Cubatão - Vila Parisi no período de 1982 a 2013

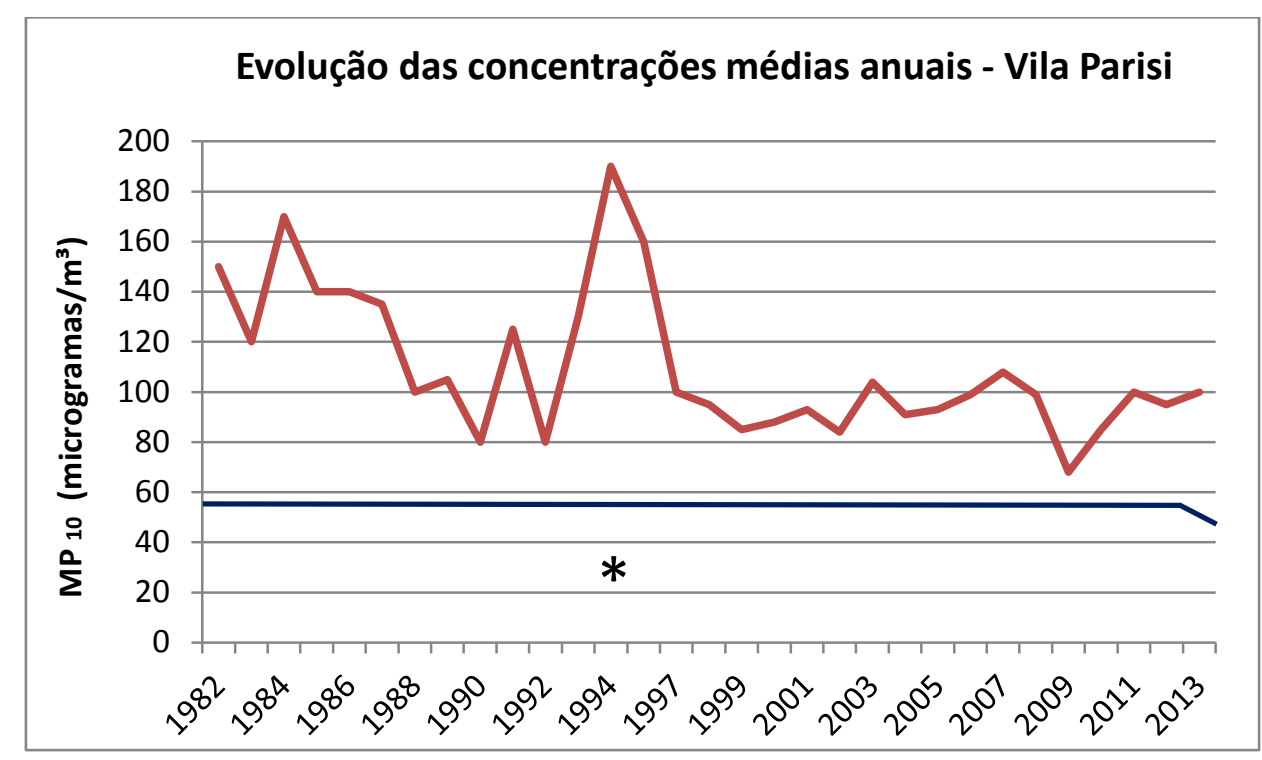

Nota 1: Padrão anual (até 2012) : $50 \mu \mathrm{g} / \mathrm{m}^{3}$; Padrão anual (a partir de 2013) : $40 \mu \mathrm{g} / \mathrm{m}^{3}$

Nota 2: $O$ valor da concentração média anual da Vila Parisi para 1996 - dados inexistentes

Fonte: Elaboração própria. Dados recuperados de relatórios de qualidade do ar CETESB, período 1985 a 2013.

As ações promovidas pela CETESB foram importantes e eficazes e os investimentos realizados nas indústrias levaram aos resultados exitosos do "Plano de Ação de Controle da Poluição de Cubatão”, que já eram percebidos no início da década de 1990. A reversão da situação ambiental crítica foi comprovada (CETESB, 2012a; CETESB, 2012b ${ }^{4}$; FERREIRA, 2007; VALARINI, 2011), levando Cubatão ao reconhecimento e outorga do título de “Cidade símbolo da recuperação ambiental”, e a entrega do selo verde, pela Organização das Nações Unidas - ONU, durante a Conferência das Nações Unidas sobre o Ambiente e o Desenvolvimento - ECO 92 (PIRES, 2012).

Além dos investimentos para o controle das emissões de fontes fixas, também teve destaque dentro do "Plano de Ação de Controle da Poluição de Cubatão", a ação de remoção do bairro de Vila Parisi, que teve início em 1985 e foi concluída em 13 de maio de 1992.

A área da antiga Vila Parisi foi então destinada a receber um terminal de cargas que foi implantado em 1995. Em função desta facilidade logística, o número de caminhões que passaram a vir para Cubatão aumentou significativamente. Com esta nova atividade

${ }^{4}$ CETESB - Relatório da Operação Inverno - 2012 - referenciado como “CETESB - serie b Relatórios da operação inverno - 2004 a 2013” 
iniciou-se uma nova dinâmica, trazendo um reflexo direto no tráfego (CIDE, 2006). Considerando os esforços na redução das emissões das fontes fixas, o CIESP adotou um plano de ações preventivas, de forma a minimizar a ressuspensão da poeira acumulada nas vias de acesso ao pátio e das estradas. Esse plano foi implantado em 1995 e permanece até os dias atuais. O período de atuação inicial foi maio a setembro (Operação Inverno) e, com o passar dos anos e a mudança do fluxo dos caminhões na região aliados a condição climática desfavorável (tempo seco), o tempo de execução do plano de ações preventivas foi estendido para o período de abril a dezembro. Percebeuse então que a dinâmica da região estava sendo alterada e a influência sobre os índices de material particulado $\mathrm{MP}_{10}$ poderiam estar sendo afetados pela nova realidade.

\section{- Período de 2001 a 2013}

As rodovias que chegam ao Município de Cubatão são, em quase sua totalidade, privatizadas. Constituem-se de vias expressas com múltiplas faixas, onde as condições de operação são muito boas, em especial no sistema Anchieta-Imigrantes (SAI). Porém, existem frequentes congestionamentos na Via Anchieta em função do aumento do número de caminhões devido às exportações, e da indisponibilidade de áreas em Santos e Guarujá para atendimento à expansão portuária e serviços retroportuários. Cubatão identificou como oportunidade para desenvolvimento, a oferta de áreas para atender a essa demanda. A partir de 2004 começaram a serem instalados novos pátios de caminhões, principalmente para recebimento de containers. (CIDE, 2006).

Conforme diagnóstico de logística realizado pelo CIDE (2006) para a elaboração da Agenda 21 de Cubatão "no setor ferroviário, a Agência Nacional de Transportes Terrestres (ANTT) concedeu direito de passagem às linhas da MRS Logística (Rede ferroviária constituída como uma Sociedade Anônima para operar a chamada Malha Sudeste da extinta Rede Ferroviária Federal S.A. (RFFSA), à Holding Brasil Ferrovias (formada pela Ferronorte, Novoeste e Ferroban), à Ferrovia Centro-Atlântica (FCA) e à América Latina Logística do Brasil (ALL). Também foi autorizada à Holding, a construção de uma segunda via férrea, da margem direita, entre Cubatão e Santos, possibilitando a ampliação da capacidade dessas ferrovias, trazendo alívio ao sistema rodoviário (CIDE, 2006, p.35). Este documento também avalia outro sistema de transporte de cargas para Cubatão.

"O sistema de cremalheira da MRS está com a capacidade praticamente esgotada no sentido Planalto-Baixada. No sentido contrário apenas 50\% é utilizada. Na mesma situação da Brasil Ferrovias, com somente $50 \%$ da capacidade em uso", e da mesma forma, "avalia o potencial de uso do transporte hídrico, como a expansão portuária (dos terminais privativos já existentes) e da utilização 
dos rios que cortam o município para transporte de cargas" (CIDE, 2006, p.36).

Observa-se, portanto, que os sistemas logísticos que atendem a região já estavam sobrecarregados e na proposta da Agenda 21 de Cubatão, em 2006, foram identificados pontos fortes e fracos para este tema na cidade. As ações efetivas para contornar as situações identificadas não foram suficientes para atender às demandas futuras que já vinham sendo delineadas. O Porto de Santos e o agronegócio continuaram expandindo e, no Município de Cubatão, foram instaladas as estruturas necessárias para atendimento ao viés econômico mais imediato, como a implantação dos pátios de caminhões para atendimento ao Porto de Santos. Porém, este crescimento não foi seguido das obras de infraestrutura necessárias para evitar os congestionamentos.

No Polo Industrial de Cubatão existe uma intensa atividade de movimentação de matérias primas e insumos, bem como a expedição da produção do Polo. Sendo assim, os picos de exportação concorrem com o tráfego de caminhões que atendem às indústrias do Polo. As figuras 15 e 16 mostram a estratificação dos principais modais utilizados na movimentação de cargas das empresas do Polo Industrial de Cubatão. Observa-se que, no período de 2008 a 2011, há aumento de recebimentos e expedições via transporte rodoviário, sendo esta a via de transporte mais utilizada para expedições.

Figura 14: Recebimentos, em toneladas, estratificados conforme o modal de transporte, Polo Industrial de Cubatão

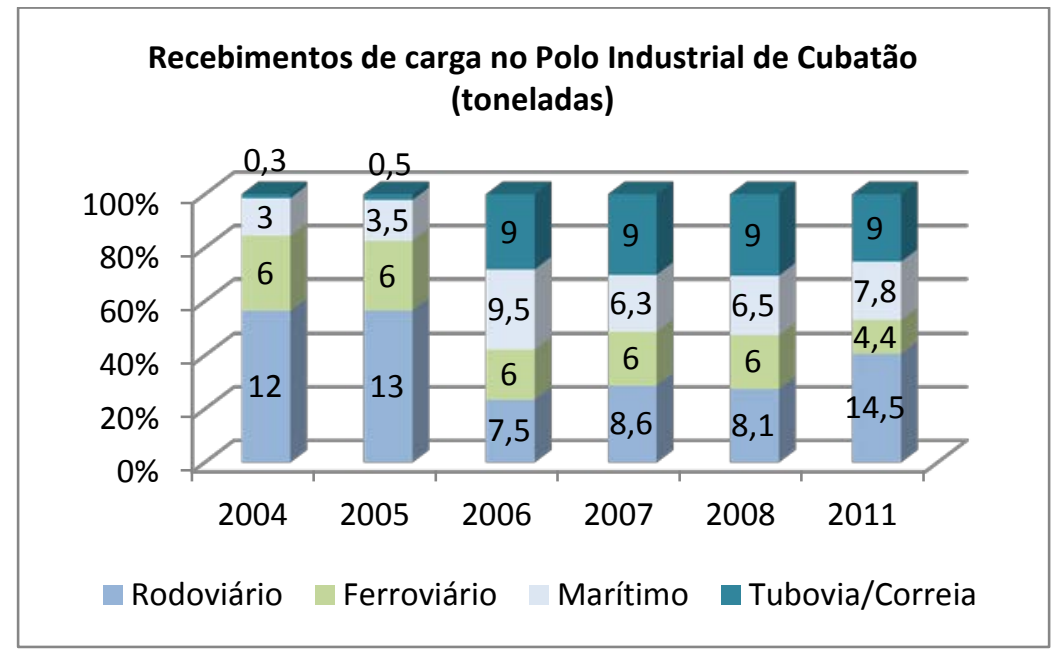

Fonte: CIESP, 2012 (Modificado) 
Figura 15: Expedições, em toneladas, estratificados conforme o modal de transporte - Polo Industrial de Cubatão

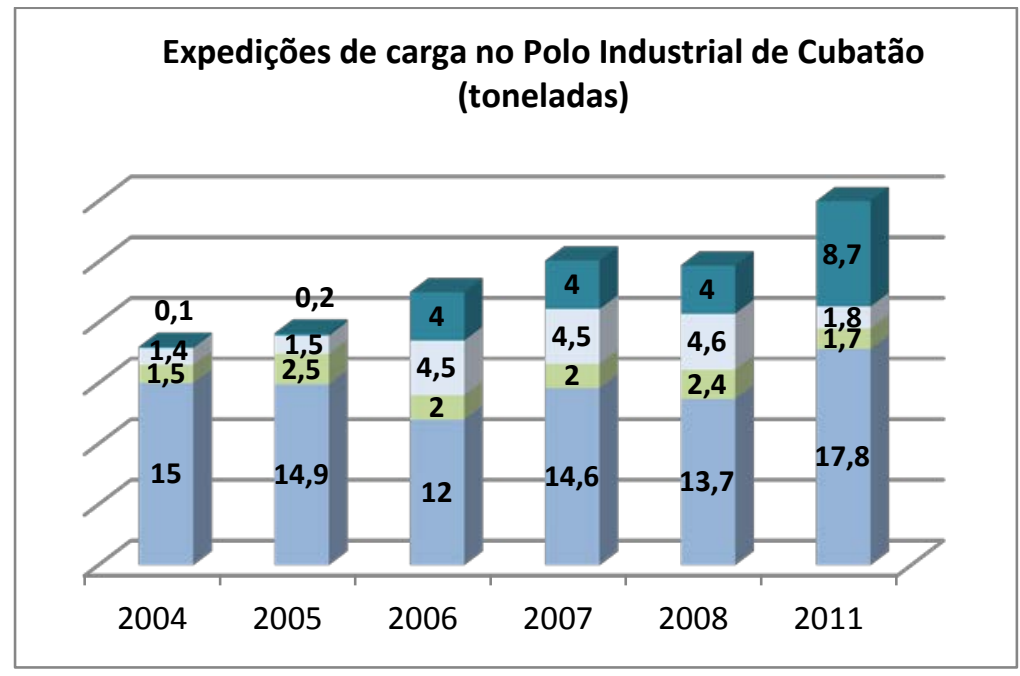

\section{Fonte: CIESP, 2012(Modificado)}

Em diversos portos, "o transporte terrestre está gerando problemas e passou a ser fonte de preocupação direta para as autoridades portuárias e os municípios em que se situam, e, indiretamente, tem reflexos negativos no cenário nacional” (PEREIRA et al, 2005, p. 2).

No caso do Porto de Santos, não há segregação física entre as vias rodoviárias e os trilhos, fazendo com que os caminhões parem sobre os trilhos, afetando a ferrovia. A falta de programação de recebimento de cargas também contribui com os congestionamentos. A frequência de congestionamentos aumenta os custos logísticos e reduzem a competitividade frente a outros portos. Outra consequência dos congestionamentos é o transtorno causado às cidades de entorno, afetando a qualidade de vida da sua população (PEREIRA et al, 2005).

"Os períodos de pico dependem não somente da safra, mas também de fatores como a balança comercial, chuvas e chegada de navios. O açúcar, por exemplo, não pode ser movimentado com mau tempo; quando há ocorrência de chuvas: os terminais param, mesmo que haja navios ancorados. Como complicador, existe ainda o fato de que são raros os terminais que programam a chegada de caminhões. Esta falta de programação faz com que alguns veículos fiquem dias parados ocupando espaço viário, à espera do navio aonde sua carga vai ser embarcada, por falta de espaço nos armazéns para estocar a carga no intervalo de 
tempo entre sua chegada no porto e o seu embarque no navio" (PEREIRA et al, 2005, p. 2).

Como descrito acima, Cubatão, mais especificamente, o Polo Industrial, recebe o reflexo de todas as sazonalidades da região, quais sejam, o fluxo do Porto de Santos e exportação de grãos, e o fluxo de veranistas para as praias da Baixada Santista. Em 2013, segundo ECOVIAS, estavam previstos mais de 450 mil veículos para as festas de final de ano.

"Para o Natal, entre os dias 20 e 26 de dezembro, são esperados 187 mil veículos circulando em ambos os sentidos da rodovia, sendo $110 \mathrm{mil} \mathrm{em}$ direção ao litoral. O movimento deve começar a se intensificar já no início da manhã de sábado (21) e picos de 1,7 mil veículos podem ser registrados entre 10h e 11h. Já para o Ano Novo - entre os dias 27 de dezembro e 2 de janeiro -, a estimativa é ainda maior: 280 mil veículos deverão passar pela $B R-277$, sendo cerca de 145 mil rumo às praias” (ECOVIAS, 2013).

O “corredor” de acesso não comporta a quantidade de veículos. Em 2013 iniciou-se a duplicação do Sistema Anchieta - Imigrantes (SAI), inclusive no trecho da Conego Domenico Rangoni. Em 2014, foi finalizada a obra, e espera-se que, com essa duplicação, o fluxo de veículos possa escoar melhor pelo “corredor” do Polo Industrial. Porém, as entradas das cidades, as entradas dos pátios e estacionamentos de caminhões em Cubatão e as áreas para recebimento de cargas no Porto de Santos, precisam assegurar condições de receber um novo fluxo de veículos, que se prevê, seja facilitado pela duplicação da rodovia.

A nova dinâmica que passou a caracterizar a região trouxe congestionamentos e transtornos. O assunto já vinha sendo discutido em fóruns de logística, sendo que uma das propostas apresentadas foi, a implantação de pátios reguladores, que seriam facilitadores da logística portuária. Conforme Pereira et al (2005), o pátio regulador de carga e caminhões permitiria o disciplinamento da movimentação de veículos carregados de produtos e das pessoas responsáveis por sua condução.

“[...]o ideal seria um planejamento das viagens de caminhão desde a origem, de modo que a carga só chegasse ao Porto na medida em que o terminal tivesse capacidade de descarregá-la. Mas esta programação desde a origem da carga acontece em poucos casos; o que se vê é uma grande quantidade 
de terminais que contam com verdadeiros 'armazéns sobre rodas', na definição das próprias empresas do setor” (PEREIRA et al, 2005, p. 5).

Com os picos de congestionamento ocorridos em 2013, medidas práticas deveriam ser adotadas para remediar o caos que se formou, acarretando transtornos para toda a região, mas para Cubatão os reflexos foram mais intensos (Figuras 16 e 17).

Figura 16: Congestionamento registrado em 24 de maio de 2013, em Cubatão

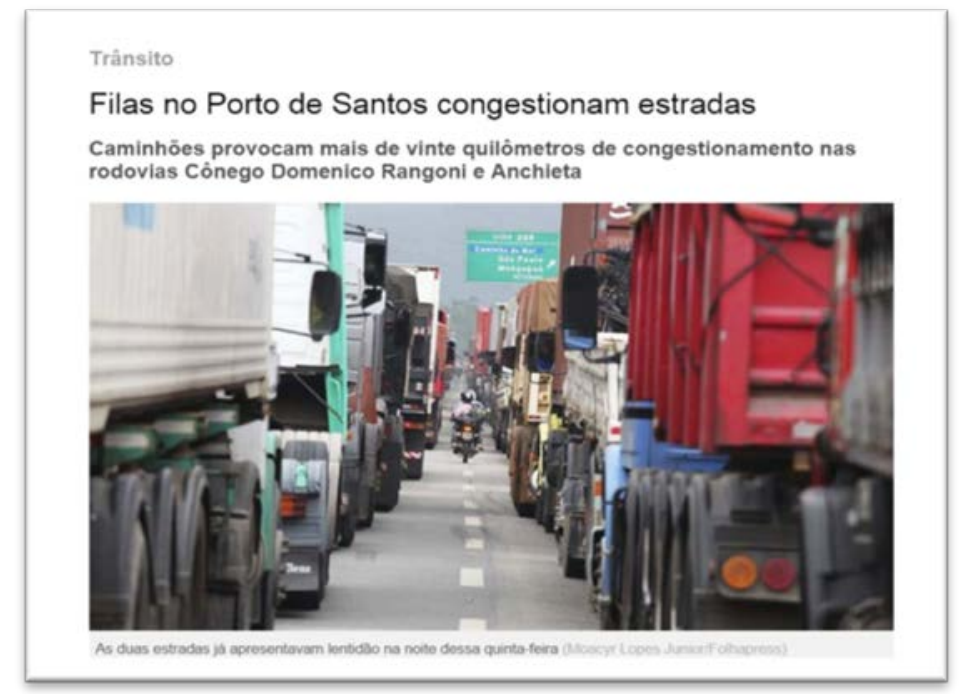

Fonte: VEJA, 2013

Figura 17: Congestionamento na Conego Domenico Rangoni, em 28/05/2013

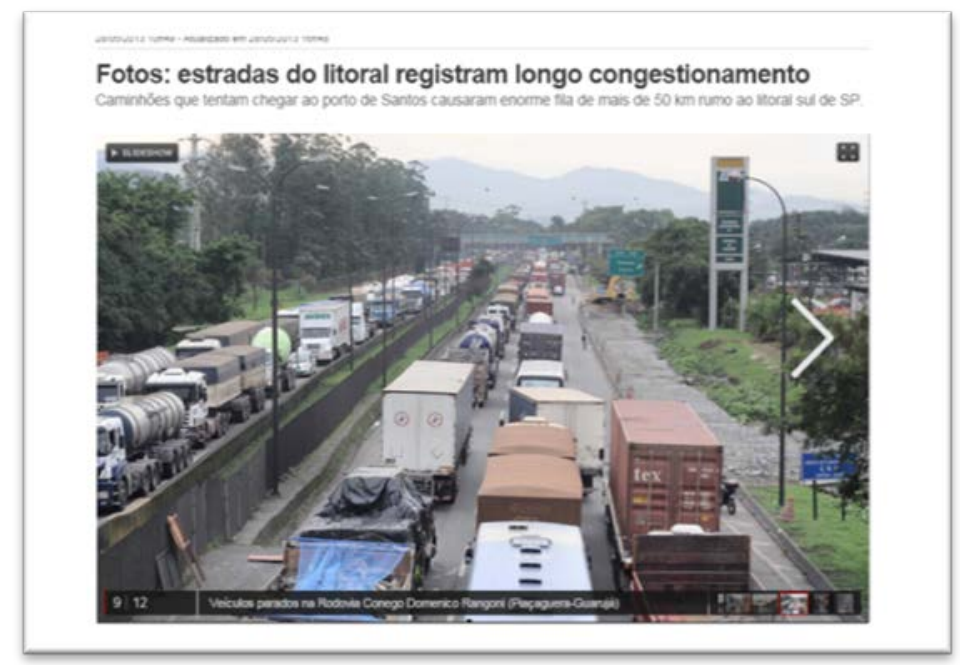

Fonte: G1, 2013 
"As filas de caminhões no acesso aos terminais do Porto de Santos provocam mais de vinte quilômetros de congestionamento nas rodovias Cônego Domenico Rangoni e Anchieta na manhã desta sexta-feira. No sentido Guarujá da Cônego já há quase dez quilômetros e, no sentido de Cubatão, o trânsito está parado do quilômetro 268 ao 270. Há reflexo das filas também na Anchieta, que apresenta congestionamento nos dois sentidos. Em direção a São Paulo, os carros estão parados do quilômetro 65 ao 55” (VEJA, 2013).

Os congestionamentos trouxeram prejuízos a diversos setores da economia e desgaste aos moradores e trabalhadores de Cubatão. Varias medidas foram sendo estudadas ao longo do ano, mas ainda continuavam os congestionamentos, estacionamento de caminhões em acostamentos, o desvio das rotas da estrada pelas ruas do Município, congestionando também o tráfego urbano, instaurando o caos na cidade nos períodos críticos de safra.

“Em 2013, motoristas chegaram a ficar até 20 dias nos pátios porque não conseguiam a liberação. Depois era preciso ter ainda mais paciência com os longos congestionamentos em um trecho de 20 quilômetros que leva ao porto. Os moradores de Cubatão foram os que mais sofreram"(CRUZ, 2014).

De acordo com Pereira et al (2005), estes congestionamentos ocasionaram ações de ampliação das estradas e implantação de pátios reguladores (ou de triagem) de caminhões para atendimento ao Porto (Figura 18). Estes foram concebidos com o objetivo de ordenar a chegada dos veículos à área portuária, funcionando como um "pulmão" para os terminais de produtos a serem embarcados nos navios. Têm a função de administrar o fluxo de veículos que se dirigem ao porto, de forma a proporcionar uma descarga contínua e reacional, sem que sejam provocados impactos negativos na sua área de entorno e transtornos à comunidade local. 
Figura 18: Pátio regulador em Cubatão

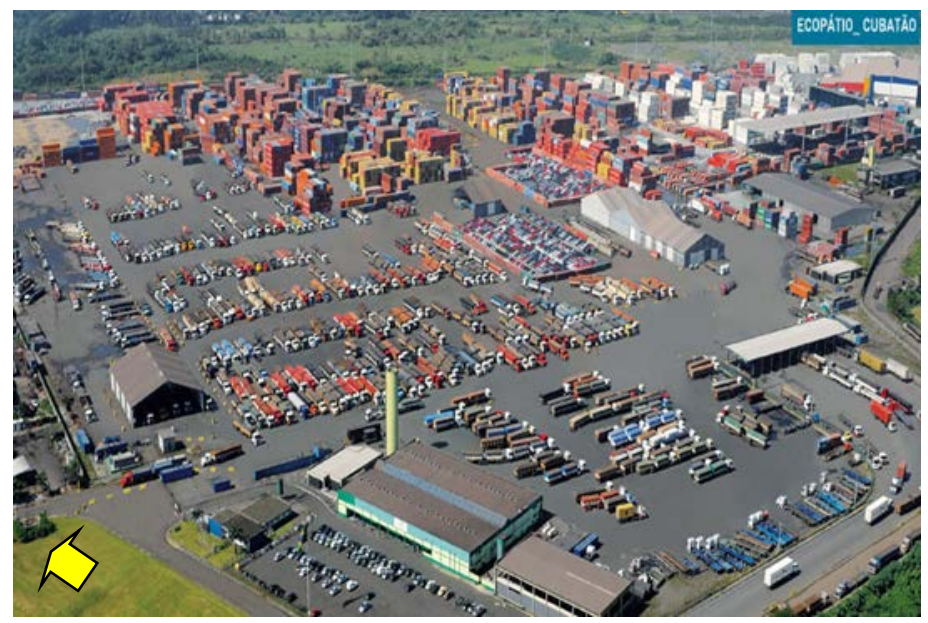

Nota: seta amarela indica local da estação medidora da Vila Parisi

Fonte: ECOPATIO Cubatão, s/d

No início de 2014, com a previsão de incremento de $10 \%$ da safra, foram propostas soluções para diminuir o impacto de seu escoamento, como a organização do acesso de navios ao porto e controle do fluxo terrestre (caminhões e trens) tomando por base o sistema já adotado pela Companhia Docas do Estado de São Paulo - CODESP. Os terminais de cargas foram mapeados em suas capacidades operacionais (capacidade de estacionamento, velocidade operacional, entre outros), para definir a capacidade máxima de cada um, e assim permitir o agendamento das viagens dos caminhões.

O controle do agendamento de viagens seria feito por uma central instalada no porto, retendo os veículos no Planalto caso fosse necessário. Essas ações foram discutidas entre a Secretaria Especial dos Portos - SEP, Prefeitura de Cubatão e Companhia Docas do Estado de São Paulo (CODESP). O sistema de agendamento passando pelos pátios reguladores na Baixada Santista foi implantado e surtiu efeito (REUTERS DOMESTIC, 2014).

"A falta de capacidade das estradas de acesso ao porto de Santos, pátios reguladores operando perto do limite e o desrespeito a agendamentos na chegada de cargas apontam para mais uma safra de soja com problemas e congestionamentos no maior complexo portuário da América Latina. Praticamente todas as cargas exportadas que chegam de caminhão precisam descer a Serra do Mar, pelas rodovias Anchieta e Imigrantes. E agora, numa tentativa de organizar um caótico fluxo, todos 
os veículos são obrigados a fazer uma parada agendada em pátios reguladores em Cubatão, a poucos quilômetros dos terminais portuários, sob ameaça de multa” (REUTERS DOMESTIC, 2014).

Em março de 2014, multas foram aplicadas para os casos de não agendamento, sendo que o índice de veículos não agendados caiu de $50 \%$ para $6 \%$ no mês que passaram a vigorar as multas (BARROS, 2014).

A partir de dados de contagem realizada pela Agência Ambiental de Cubatão nos trechos das estradas que passam pelo Polo Industrial estimou-se que a frota de caminhões que circula anualmente nos trechos das rodovias é de aproximadamente 3,3 milhões de veículos. Para este cálculo, considera-se que a maior parte das indústrias, dos pátios de recebimento de cargas e caminhões e do Porto de Santos funciona sem interrupções. A frota circulante de caminhões foi estimada em 840.960, no trecho da Anchieta e 2.522.880, no trecho da Rodovia Cônego Domenico Rangoni (CETESB, 2014a). Com base nas informações trazidas, observa-se que o fluxo de caminhões é muito mais intenso na Rodovia Conego Domenico Rangoni e que, mesmo com as medidas de agendamento de cargas no Porto de Santos adotadas e surtindo efeito, evitando congestionamentos frequentes, os pátios estão operando no limite, há descumprimento das regras e é necessário que seja repensada a forma de recebimento e operação da logística de transporte de grãos e outros produtos, para demandas futuras na região, como o possível incremento da produção de petróleo, concorrência com veículos de passeio, caminhões que atendam à produção das indústrias e aumento da exportação de grãos.

Ressalta-se ainda que, em 2013, foram publicados os novos padrões de qualidade do ar no Estado de São Paulo, que foram revisados pelo Decreto Estadual no 59.113, de 23 de abril de 2013, ficando mais restritivos. Com isto, o monitoramento das estações medidoras e os relatórios da qualidade do ar emitidos pela CETESB, passaram a demonstrar outro cenário ambiental para a realidade de Cubatão. A associação do monitoramento da qualidade do ar, não pode estar dissociada à movimentação dos veículos na região, uma vez que as estações medidoras da Vila Parisi e do Vale do Mogi estão lotadas em áreas de circulação intensa de veículos, qual seja a entrada dos principais pátios de caminhões do Polo Industrial.

\subsection{3 - Considerações sobre o Item}

O histórico apresentado neste capítulo é importante para identificação das ações em curso e a forma com que estas ocorreram. As primeiras ações foram reativas. A partir da implantação do monitoramento da qualidade do ar no Estado de São Paulo, e em especial, das ações emergenciais para Cubatão. Com a situação mais controlada e as consequências sendo mitigadas, as ações passaram a ser adotadas em caráter corretivo ou preventivo, chegando a êxito, com a não ocorrência de episódios críticos de qualidade do ar (estados de Alerta e Emergência) desde 1995. Foi identificado também 
que na tomada de ações, sejam estas diretrizes de governo ou respostas a consequências, houve uma demora na aplicação destas.

Avaliou-se que o sucesso das ações implantadas em Cubatão para controle da poluição, foi devido a uma centralização de esforços e vontade política, considerando uma realidade específica da região, com participação importante das entidades envolvidas, no desenvolvimento de objetivos e metas a serem alcançadas.

A dinâmica da região vem se alterando de uma forma mais rápida que nos períodos anteriores, e, apesar de haver a percepção das mudanças por vários segmentos da sociedade, as ações têm resposta lenta, não acompanhando o ritmo das mudanças.

Fica claro que, em Cubatão, uma nova dinâmica vem sendo implantada, e, após um período crítico de congestionamentos e prejuízos a diversos setores e incômodo à população local e circulante, novamente houve a necessidade de se trabalhar em conjunto, para que as soluções fossem propostas e os benefícios e ônus para cada uma das partes pudessem ser discutidos. Os congestionamentos não ocorreram com a mesma intensidade em 2014, porém o tráfego intenso permanece e, apesar do agendamento, as condições climáticas e outros fatores, ainda podem causar novos transtornos à região. Contar apenas com as ações atuais, como o agendamento das cargas, não é suficiente para solucionar o problema. Para buscar a solução é necessário o envolvimento de vários segmentos, com foco no problema e envolvimento nas ações.

Para esta pesquisa, que tem por foco a identificação das alterações da dinâmica da região, suas consequências e, suas influências nos índices de material particulado $\mathrm{MP}_{10}$ em Cubatão, as informações decorrentes do monitoramento da qualidade do ar, são imprescindíveis para o auxílio na tomada de decisões, para o planejamento do desenvolvimento da região.

Sendo assim, é importante, conhecer como está estruturada a gestão da qualidade do ar no Estado de São Paulo, tópico que será abordado no próximo capítulo.

\subsection{Gestão da qualidade do ar no Estado de São Paulo}

Conforme discorrido no item 2.1, o histórico de desenvolvimento de Cubatão levou a condições críticas de poluição do ar necessitando que medidas de gestão fossem implantadas. O parâmetro de interesse é o material particulado. Cabe, portanto, uma breve explanação sobre o que é material particulado, como se forma e porque se converteu em um problema tão significativo para Cubatão. 


\subsection{1 - Material particulado}

Segundo Manahan ${ }^{5}$ (2005), citado por Valarini (2011, p.3) o “material particulado ou aerossol é constituído por partículas sólidas ou líquidas em suspensão na atmosfera. Sua composição e tamanho dependem das fontes de emissão e dos processos físico-químicos que ocorrem no ambiente. Seu tamanho pode variar de nanômetros ${ }^{6}(\mathrm{~nm})$ a dezenas de micrômetros ${ }^{7}(\mu \mathrm{m})$ de diâmetro".

Nesta pesquisa o parâmetro de interesse é o $\mathrm{MP}_{10}$. O material particulado inalável $\left(\mathrm{MP}_{10}\right)$ é constituído por partículas que possuem diâmetro aerodinâmico equivalente menor que $10 \mu \mathrm{m}$. Essas partículas estão distribuídas em diâmetros aerodinâmicos equivalentes variados como Material Particulado Fino $\left(\mathrm{MP}_{2,5}\right)$ e Material Particulado Grosso $\left(\mathrm{MP}_{2,5-10}\right)$. O índice $\mathrm{MP}_{10}$ é, portanto, composto pela soma do $\mathrm{MP}_{2,5}$ e $\mathrm{MP}_{2,5-10}$ (VALARINI, 2011).

O material particulado na atmosfera pode ser formado por fontes naturais (vulcões, incêndios, sprays marinhos e plantas) e por fontes antropogênicas (indústrias, processos de extração e processo de minérios e combustão). Na combustão consideram-se os fornos, termelétricas e motores de veículos. Dentro da composição do MP relativo ao processo de combustão estão também as partículas Black Carbon (BC), que é o carbono elementar ou carbono orgânico, que pode ser considerado como traçador de emissões veiculares (VALARINI, 2011).

Do ponto de vista da saúde pública, o Material Particulado Fino $\left(\mathrm{MP}_{2,5}\right)$, ou seja, as partículas que possuem diâmetro aerodinâmico equivalente entre 0,1 a 2,5 $\mu \mathrm{m}$ são as mais importantes. As partículas grossas $\left(\mathrm{MP}_{2,5-10}\right)$ são geralmente formadas por processos mecânicos e permanecem na atmosfera por um período de tempo mais curto (VALARINI, 2011).

"Partículas inaláveis $\left(\mathrm{MP}_{10}\right)$ : Podem ser definidas de maneira simplificada como aquelas cujo diâmetro aerodinâmico é menor que $10 \mu \mathrm{m}$. As partículas inaláveis podem ainda ser classificadas como partículas inaláveis finas $-M P_{2,5}(<2,5 \mu \mathrm{m})$ e partículas inaláveis grossas $(2,5$ a $10 \mu \mathrm{m})$. As partículas finas, devido ao seu tamanho diminuto, podem atingir os alvéolos pulmonares, já as grossas ficam retidas na parte superior do sistema respiratório" (SANTOS, 2010, p. 21).

\footnotetext{
${ }^{5}$ MANAHAN, S.E. Environmental Chemistry. 8th ed. Florida. CRC Press LLC, 2005, p. 279.

${ }^{6} 1$ nanômetro é igual a um bilionésimo do metro

${ }^{7} 1$ micrômetro é igual a um milionésimo do metro.
} 


\subsection{2 - Climatologia e topografia}

A qualidade do ar não está relacionada apenas às fontes emissoras, mas também como a atmosfera age em concentrar ou dispersar os poluentes, e são influenciadas fortemente por condições meteorológicas como velocidade dos ventos e estabilidade atmosférica (NASCIMENTO, 2010). Para fins desta pesquisa é de suma importância o entendimento da localização do Município de Cubatão e as características climáticas da região em que está inserido.

A localização geográfica do Município, o regime de ventos e os períodos secos, durante o inverno, levaram a condições críticas para a qualidade do ar, como a dificuldade de dispersão e concentração de poluentes.

Outro fator meteorológico de grande influência na qualidade do ar é a precipitação, pois as chuvas ajudam a "limpar" a atmosfera. A climatologia anual de Cubatão segue um padrão esperado de clima tropical e úmido, com verões quentes e úmidos, invernos frios e secos. O material particulado apresenta índices mais elevados nos meses de inverno em razão de fatores como a baixa umidade, que faz com que o MP permaneça na atmosfera por mais tempo. As temperaturas mais baixas colaboram na maior quantidade de MP, pois diminuem a turbulência térmica, fazendo com que a altura da camada de mistura diminua, aumentando ainda mais a concentração. A climatologia diária das variáveis meteorológicas também segue um padrão esperado, com a diminuição da pressão e umidade relativa ao longo do dia, à medida que a temperatura aumenta, gerando a circulação da brisa marítima.

"A evolução diurna do MP, está relacionada à associação de vários fatores, sendo os principais: 1. Emissão: por exemplo: a variação temporal das emissões industriais e veiculares, a ressuspensão de partículas aumentando a concentração de MPG [material particulado grosso]. 2. Condições atmosféricas; por exemplo: aumento da temperatura que aumenta a turbulência térmica, que faz com que a altura da camada limite se eleve e diminua a concentração de MP; as chuvas e as UR mais altas fazem com que o MP diminua; a nebulosidade pode diminuir as reações químicas que ocorrem na atmosfera, importantes na geração de MP secundário, como o sulfato; ventos mais intensos ressuspendem mais poeira, mas ao mesmo tempo auxiliam na dispersão de poluentes" (VALARINI, 2011, p.40 e 41). 
Considerando as informações acima, vê-se que a característica de Cubatão é peculiar, sendo este um fator primordial para que o quadro de poluição do ar tenha se agravado, tornando-se crítico.

\subsection{3 - Qualidade do ar}

- Padrões de qualidade do ar - válidos até 2012

Até 2012, os padrões de qualidade do ar no Estado de São Paulo (PQAr) estavam definidos no Decreto Estadual no 8468/76 e na Resolução CONAMA no 3 de 28/06/90 , como padrões nacionais (CETESB, 2012b ${ }^{5}$, p.2).

Conforme descrito no relatório CETESB $\left(2012 \mathrm{a}^{4}\right)$, os dados de qualidade do ar e meteorológicos das estações automáticas de monitoramento são divulgados e continuamente atualizados no endereço eletrônico da CETESB, bem como a classificação da qualidade do ar. Esta classificação se dá por meio de um índice, obtido por cálculo, utilizando-se ferramenta matemática desenvolvida para simplificar o processo de divulgação (CETESB, 2012a ${ }^{4}$ ).

A classificação do índice da qualidade do ar em função das concentrações medidas e, posteriormente, validadas pela CETESB tem sua estrutura demonstrada no Quadro 1 , representando a qualidade do ar segundo uma escala de cores, com destaque para o material particulado $\left(\mathrm{MP}_{10}\right)\left(\mathrm{CETESB}, 2012 \mathrm{a}^{4}\right)$. 
Quadro 1: Classificação do índice da qualidade do ar, para o parâmetro MP10, com destaque para as condições que passam a ser consideradas como episódios críticos (Continua)

\begin{tabular}{|c|c|c|c|}
\hline CRITÉRIO & $\begin{array}{l}\text { ÍNDICE DE } \\
\text { QUALIDADE } \\
\text { DO AR }\end{array}$ & $\begin{array}{c}\text { MP }_{10} \\
\left(\mu g / m^{3}\right)\end{array}$ & SIGNIFICADO \\
\hline Boa & 0 - 50 & $0-50$ & Praticamente não há riscos à saúde. \\
\hline Regular & $51-100$ & $>50-150$ & $\begin{array}{l}\text { Pessoas de grupos sensíveis (crianças, idosos e pessoas } \\
\text { com doenças respiratórias e cardíacas) podem } \\
\text { apresentar sintomas como tosse seca e cansaço. A } \\
\text { população, em geral, não é afetada. }\end{array}$ \\
\hline Inadequada & $101-199$ & $\begin{array}{ll}>150 & \text { e } \\
<250\end{array}$ & $\begin{array}{l}\text { Toda a população pode apresentar sintomas como tosse } \\
\text { seca, cansaço, ardor nos olhos, nariz e garganta. } \\
\text { Pessoas de grupos sensíveis (crianças, idosos e pessoas } \\
\text { com doenças respiratórias e cardíacas) podem } \\
\text { apresentar efeitos mais sérios na saúde. }\end{array}$ \\
\hline Má & $200-299$ & $\begin{array}{l}>=250 \quad \text { e } \\
<420\end{array}$ & $\begin{array}{l}\text { Toda a população pode apresentar agravamento dos } \\
\text { sintomas como tosse seca, cansaço, ardor nos olhos, } \\
\text { nariz e garganta e ainda apresentar falta de ar e } \\
\text { respiração ofegante. Efeitos ainda mais graves à saúde } \\
\text { dos grupos de pessoas sensíveis (crianças, idosos e } \\
\text { pessoas com doenças respiratórias ou cardíacas) }\end{array}$ \\
\hline Péssima & $>=300$ & $>=420$ & $\begin{array}{l}\text { Toda a população pode apresentar sérios riscos de } \\
\text { manifestação de doenças respiratórias e } \\
\text { cardiovasculares. Aumento de mortes prematuras em } \\
\text { pessoas de grupos sensíveis. }\end{array}$ \\
\hline
\end{tabular}

Nota: Tanto a classificação BOA como REGULAR indicam que a qualidade do ar obedece aos padrões legais, ou seja, abaixo do PQAr primário. Os níveis de qualidade do ar, bem como a previsão das condições meteorológicas de dispersão de poluentes, são divulgados no endereço internet $w$ ww.cetesb.sp.gov.br

Fonte: CETESB, $2012 b^{5}$, p. 04 (modificado)

\section{- Episódios críticos}

No Título III, do Decreto Estadual $\mathrm{n}^{\circ}$ 8.468, de 08 de setembro de 1976, é tratada a gestão ambiental para a qualidade do ar no Estado. No capítulo III, que trata do "Plano de Emergência para Episódios Críticos de Poluição do Ar”, foram estabelecidos padrões que determinam a criticidade da qualidade do ar em zonas saturadas e ações de gestão a serem adotadas para cada situação em que estes padrões sejam ultrapassados e que caracterizem a ocorrência de episódios críticos de poluição do ar, normalmente associados ao período do Inverno (CETESB, 2012b ${ }^{5}$ ). 
A definição quanto à caracterização dos episódios críticos de poluição do ar, foi estabelecida em função dos padrões descritos no Quadro 1 para o parâmetro particulado $\left(\mathrm{MP}_{10}\right)$, considerando os efeitos sobre a saúde humana e, tendo sido considerados também as principais fontes, características dos poluentes e os efeitos ao meio ambiente (Quadro 2).

Quadro 2: Fontes, características e efeitos dos principais poluentes da atmosfera

\begin{tabular}{|c|c|c|c|}
\hline POLUENTE & CARACTERÍSTICAS & $\begin{array}{l}\text { FONTES } \\
\text { PRINCIPAIS }\end{array}$ & $\begin{array}{l}\text { EFEITOS } \\
\text { GERAIS AO } \\
\text { MEIO } \\
\text { AMBIENTE }\end{array}$ \\
\hline $\begin{array}{l}\text { Partículas inaláveis } \\
\left(\mathrm{MP}_{10}\right) \text { e Fumaça }\end{array}$ & $\begin{array}{l}\text { Partículas de material } \\
\text { sólido ou líquido que } \\
\text { ficam suspensas no ar, } \\
\text { na forma de poeira, } \\
\text { neblina, aerossol, } \\
\text { fumaça, fuligem etc. } \\
\text { Faixa de tamanho <10 } \\
\text { micra. }\end{array}$ & $\begin{array}{l}\text { Processos de combustão } \\
\text { (indústrias e veículos } \\
\text { automotores), poeira } \\
\text { ressuspensa, aerossol } \\
\text { secundário (formado na } \\
\text { atmosfera). }\end{array}$ & $\begin{array}{l}\text { Danos à vegetação, } \\
\text { deterioração da } \\
\text { visibilidade, } \\
\text { contaminação do } \\
\text { solo e da água. }\end{array}$ \\
\hline
\end{tabular}

Fonte: CETESB, $2012 b^{5}$, p. 02 (modificado)

No Quadro 3 estão descritos os padrões de qualidade do ar, com destaque para material particulado $\left(\mathrm{MP}_{10}\right)$. Os padrões primários referem-se ao material particulado lançado diretamente na atmosfera, como emissões de fontes fixas e móveis e ressuspensão de poeiras. Os padrões secundários referem-se a partículas formadas na atmosfera por meio de reações químicas ou fotoquímicas. Também neste mesmo quadro, estão estabelecidas as concentrações de material particulado que caracterizam os episódios críticos de poluição, que estão categorizados por estados de Atenção, Alerta ou Emergência.

Ressalta-se que os padrões de qualidade do ar no Estado de São Paulo foram revisados pelo Decreto Estadual ${ }^{0}$ 59.113, de 23 de abril de 2013, tornando-se mais restritivos. Entretanto, os padrões e critérios estabelecidos para a caracterização de episódios críticos de poluição do ar permanecem inalterados até o momento. Os padrões de qualidade do ar, previstos na Resolução CONAMA n 05, de 15 de junho de 1989, permanecem em vigência, apesar de encontrar-se em fase de revisão. 
Quadro 3: Padrões de Qualidade do Ar e Critérios para Episódios Críticos de Poluição, com destaque para o parâmetro material particulado $M P_{10}$, válidos até 2012 para o Estado de São Paulo

\begin{tabular}{|c|c|c|c|c|c|c|}
\hline POLUENTE & $\begin{array}{l}\text { TEMPO } \\
\text { AMOSTRAGEM }\end{array}$ & $\begin{array}{l}\text { PADRÃO } \\
\text { PRIMÁRIO } \\
\left(\mu \mathrm{g} / \mathrm{m}^{3}\right)\end{array}$ & $\begin{array}{l}\text { PADRÃO } \\
\text { SECUNDÁRIO } \\
\left(\mu \mathrm{g} / \mathbf{m}^{3}\right)\end{array}$ & $\begin{array}{l}\text { ATENÇÃO } \\
\left(\mu \mathrm{g} / \mathrm{m}^{3}\right)\end{array}$ & $\begin{array}{l}\text { ALERTA } \\
\left(\mu \mathrm{g} / \mathrm{m}^{3}\right)\end{array}$ & $\begin{array}{l}\text { EMERGÊNCIA } \\
\left(\mu \mathrm{g} / \mathrm{m}^{3}\right)\end{array}$ \\
\hline $\begin{array}{l}\text { Partículas } \\
\text { inaláveis } \\
\left(\mathrm{MP}_{10}\right) \text { e } \\
\text { Fumaça }\end{array}$ & $\begin{array}{l}24 \text { horas }^{1} \\
\text { MAA }^{2}\end{array}$ & $\begin{array}{l}150 \\
50\end{array}$ & $\begin{array}{l}150 \\
50\end{array}$ & 250 & 420 & 500 \\
\hline
\end{tabular}

Nota: 1.Não deve ser excedido mais que uma vez ao ano / 2.Média aritmética anual Fonte: CETESB, $2012 b^{5}$, p.03 (Modificado)

Na ocorrência de episódios críticos de poluição, considerando os valores para material particulado $\left(\mathrm{MP}_{10}\right)$ até 2012, as informações constantes do site da CETESB, para qualidade do ar, apresentam os critérios e significados, conforme Quadro 4.

Quadro 4: Episódios Críticos de Poluição e seu significado, com destaque para o parâmetro material particulado $M P_{10}$, válidos até 2012 para o Estado de São Paulo

\begin{tabular}{|c|c|c|c|}
\hline CRITÉRIO & $\begin{array}{l}\text { ÍNDICE DE } \\
\text { QUALIDADE } \\
\text { DO AR }\end{array}$ & $\begin{array}{l}M P_{10} \\
\left(\mu g / m^{3}\right)\end{array}$ & SIGNIFICADO \\
\hline Má & $200-299$ & $\begin{array}{l}>=250 \\
\text { (Atenção) } \\
\mathrm{e} \\
<420 \\
\text { (Alerta) }\end{array}$ & $\begin{array}{l}\text { Toda a população pode apresentar } \\
\text { agravamento dos sintomas como tosse seca, } \\
\text { cansaço, ardor nos olhos, nariz e garganta e } \\
\text { ainda apresentar falta de ar e respiração } \\
\text { ofegante. Efeitos ainda mais graves à saúde } \\
\text { dos grupos de pessoas sensíveis (crianças, } \\
\text { idosos e pessoas com doenças respiratórias ou } \\
\text { cardíacas) }\end{array}$ \\
\hline Péssima & $>=300$ & $\begin{array}{l}>=420 \\
\text { (Emergência) }\end{array}$ & $\begin{array}{l}\text { Toda a população pode apresentar sérios riscos } \\
\text { de manifestação de doenças respiratórias e } \\
\text { cardiovasculares. Aumento de mortes } \\
\text { prematuras em pessoas de grupos sensíveis. }\end{array}$ \\
\hline
\end{tabular}

Fonte: CETESB, $2012 b^{5}$, p.04 (Modificado) 


\section{- Rede de monitoramento}

Para monitorar a qualidade do ar, a CETESB baseia-se nas informações obtidas pelas estações medidoras instaladas no Polo Industrial de Cubatão (Cubatão-V. Parisi e Cubatão-V. Mogi) e no centro da cidade (Cubatão-Centro), sendo estes, atualmente, os parâmetros que norteiam a tomada de decisão e adoção de medidas de controle ambiental para os casos de episódios críticos de poluição do ar.

É importante que se considere a localização da rede de monitoramento da CETESB em Cubatão, uma vez que esta pode estar sendo influenciada pela dinâmica de ocupação da região.

A CETESB vem operando uma rede automática de monitoramento da qualidade do ar desde 1981 e uma rede manual que mede os teores de enxofre/fumaça desde 1973, monóxido de carbono desde 1976 e partículas em suspensão desde 1983 (CETESB, $1985 a^{8}$, p.29).

Em Cubatão, foram instaladas inicialmente 03 estações medidoras (V. Nova, Vila Parisi e Centro). Em 1996, a estação de Vila Nova foi desativada. Em 2005 foi instalada a estação medidora do Vale do Mogi. Atualmente, Cubatão conta com uma rede de monitoramento composta por 03 estações medidoras de qualidade do ar (Vila Parisi, Cubatão-Centro e Vale do Mogi) que desde a data de suas instalações permanecem posicionadas no mesmo local.

As estações da área industrial foram implantadas onde, atualmente, estão também os pátios de caminhões. Segundo a Agência Ambiental da CETESB de Cubatão, citada por Figueiredo et al (2014), as estações mais afetadas pela circulação de veículos são as localizadas na área industrial, visto que o pátio usado pelos caminhões se localiza nessa região e que anteriormente à pavimentação do pátio, a suspensão de partículas decorrente da movimentação dos veículos e seus escapamentos contribuía de forma importante para a elevação dos índices poluentes no ar.

Nos últimos 10 anos, houve uma ampliação das atividades onde está localizada a estação do Vale do Mogi. Além da expansão das atividades industriais no fundo do vale, observa-se também a ampliação de um pátio de caminhões. Ocorre que houve um aumento do fluxo de caminhões no entorno da estação, uma vez que esta está localizada próxima à entrada do pátio.

As figuras 19 e 20 mostram a localização da estação medidora da Vila Parisi, observando-se que o fluxo de caminhões ao lado da estação medidora é intenso.

\footnotetext{
${ }^{8}$ CETESB - Relatório da Qualidade do Ar - 1985 - referenciado como "CETESB - serie a Relatórios da Qualidade do Ar - 1985 a 2013”
} 
Figura 19: Cenário na região próxima à Estação medidora V. Parisi (2010)

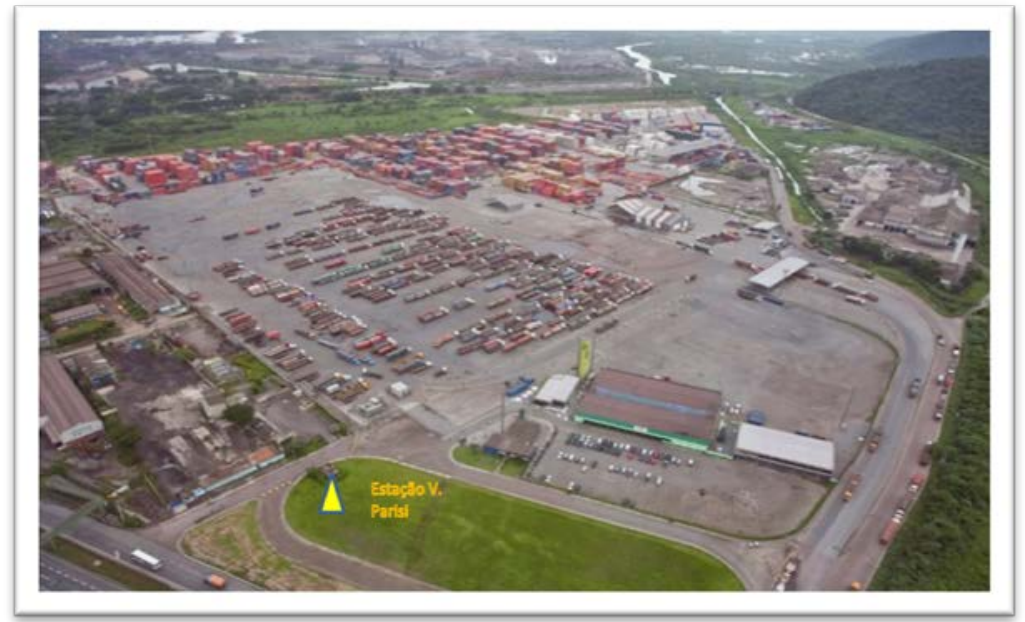

Nota: A seta amarela indica a localização da estação medidora de V. Parisi Fonte: ECOPATIO, 2014

Figura 20: Vista da estação medidora da V. Parisi durante campanha de limpeza

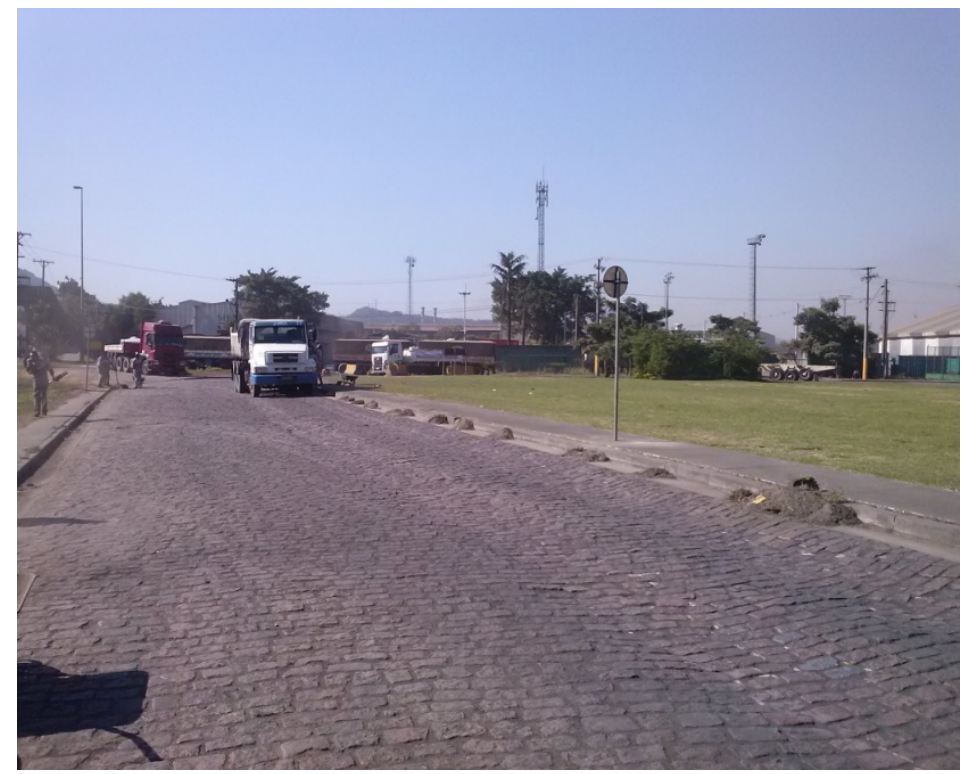

Fonte: CIESP, 2013.

Em julho de 2013, foi publicado pela CETESB o relatório “Classificação preliminar da representatividade espacial das estações de monitoramento da qualidade do ar da CETESB no Estado de São Paulo". De acordo com este relatório, a rede de monitoramento atual foi concebida de forma a considerar as principais características da região e os principais poluentes.

A definição dos pontos para instalação das estações medidoras de qualidade do ar, quando da sua instalação em Cubatão, iniciadas na década de 1970 (Cubatão-Vila 
Nova, Cubatão-Centro e Cubatão-Vila Parisi) atendia plenamente aos conceitos discriminados, quais sejam: representavam as áreas de maior densidade populacional, bem como representavam as áreas de maior impacto da poluição no meio ambiente devido a determinadas fontes ou grupos de fontes. As unidades de Cubatão-Vila Nova e Cubatão-Centro, com características típicas de bairro e núcleos urbanos, e a unidade Cubatão-V. Parisi, que tinha ocupação urbana, dentro de uma área industrial.

As informações obtidas destas estações foram decisivas para o estabelecimento do Plano de Controle de Poluição Ambiental de Cubatão.

Uma das ações previstas neste Plano foi a remoção da Vila Parisi, retirando os moradores do local, eliminando a exposição daquela população específica aos efeitos da poluição do ar. O zoneamento foi implantado pela Prefeitura de Cubatão, de forma que ali passou a ser uma zona industrial (FERREIRA, 2007).

Atualmente, as estações medidoras em operação são as denominadas: Cubatão- Centro, Cubatão - V. Parisi e Cubatão -V. Mogi, sendo que esta última foi instalada em 2005. A estação Cubatão - V. Nova foi desativada. (CETESB, 2001a ${ }^{9}$ ).

A partir de 2004 (CIESP, 2012), ocorreu incremento na atividade de logística no polo industrial de Cubatão (pátio de caminhões), que já era uma atividade existente. Os pátios existentes anteriormente no Polo Industrial atendiam às demandas locais, e mesmo que, em função da circulação próxima às estações fossem necessárias ações complementares para evitar a ressuspensão de poeiras, o fluxo ainda era compatível com a dinâmica da região.

Essa conclusão foi identificada nas avaliações anuais da qualidade do ar em Cubatão, para a estação Cubatão - V. Parisi (CETESB, 2004a ${ }^{10}$;CETESB,2005a ${ }^{11}$ ), que as alterações nos índices de qualidade do ar vinham ocorrendo, sendo que neste último relatório, foi feita uma análise do período de implantação das ações previstas no Plano de Controle de Poluição Ambiental de Cubatão comparando com a evolução alcançada.

"A análise dos dados de $M P_{10}$ indicavam uma queda constante a partir de 1997, embora ainda bem acima do padrão de qualidade do ar. No entanto, de 2003 a 2005 as concentrações medidas foram mais altas que as observadas no período de 1999 a 2002 ” (CETESB, 2005a ${ }^{11}$, p.II).

A alteração de fluxo também foi identificada pela CETESB, conforme descrito no relatório de qualidade do ar de 2006.

\footnotetext{
${ }^{9}$ CETESB - Relatório da Qualidade do Ar - 2001 - referenciado como "CETESB - serie a Relatórios da Qualidade do Ar - 1985 a 2013”

${ }^{10}$ CETESB - Relatório da Qualidade do Ar - 2004 - referenciado como "CETESB - serie a Relatórios da Qualidade do Ar - 1985 a 2013”
} 
“A principal preocupação em Vila Parisi, na área industrial, são as altas concentrações de material particulado. [...] Os níveis caíram significativamente nos anos 80 e 90. Mais recentemente, alterações no entorno da estação, sobretudo o impacto do tráfego local de caminhões, tem levado a níveis mais elevados que os que eram observados no final da década de 90" (CETESB, 2006a ${ }^{11}$, p. II e III).

Da mesma forma, no relatório anual de qualidade do ar de 2007, foi avaliado que o fluxo de caminhões interfere na qualidade do ar da região, observando que ocorreu alteração do regime típico das concentrações de material particulado, conforme as estações do ano, ou seja, o que antes se caracterizava principalmente durante o inverno, em função das condições climáticas desfavoráveis, passou a ser uma constante, em função do fluxo de veículos no entorno da estação.

"Observa-se que o aumento das concentrações no inverno não é tão perceptível pois devido às emissões industriais e à movimentação de caminhões nas proximidades da estação, os níveis de poluição se mantêm altos mesmo nos meses mais quentes" (CETESB, 2007a ${ }^{12}$, p. 133).

\section{- Classificação das estações telemétricas no Estado de São Paulo}

Para o gerenciamento da qualidade do ar no Estado de São Paulo utiliza-se comparação das concentrações ambientais de poluentes específicos com os padrões da qualidade do ar. Com a promulgação do Decreto Estadual no 59113, de 23 de abril de 2013, que estabelece novos padrões de qualidade do ar, novas ações de gerenciamento deverão ser adotadas.

Sendo assim, para suporte à tomada de decisão na implantação deste Decreto Estadual, foi publicado, em julho de 2013, um relatório de classificação preliminar das estações medidoras da qualidade do ar no Estado, de forma a identificar aquelas que pudessem ter significativa influência das emissões veiculares e serem classificadas como microescala. $\mathrm{O}$ artigo $5^{\circ}$ do referido Decreto Estadual estabelece que as estações com significativa influência de emissões veiculares e classificadas como microescala para os padrões primários poderão, a critério da CETESB, não ter seus dados considerados para a classificação da qualidade do ar, de uma sub-região.

${ }^{11}$ CETESB - Relatório da Qualidade do Ar - 2006 - referenciado como "CETESB - serie a Relatórios da Qualidade do Ar - 1985 a 2013” 
Foram adotados os critérios de classificação, a localização da estação, o poluente de interesse, a proximidade das fontes de emissão, a intensidade das emissões, as condições de topografia, o relevo e o transporte dos poluentes, além das características do entorno em relação ao uso do solo, considerando também a posição da sonda de amostragem em relação à altura de captação e proximidade de obstáculos (CETESB, 2013d). Abaixo são descritos os critérios utilizados para classificação de estações de microescala com influência veicular, para o poluente material particulado. Como regra geral, foi estabelecido que:

"De maneira geral, estes critérios foram adotados para avaliar as escalas de representatividade das estações da CETESB: estações a menos de $15 \mathrm{~m}$ da principal via de tráfego foram classificadas como microescala. No caso de via com baixa densidade de tráfego, as estações foram classificadas em função da via principal mais próxima” (CETESB, 2013d, p. 3).

"As estações localizadas a distâncias entre $5 \mathrm{~m} e$ $15 \mathrm{~m}$ de um corredor de tráfego, com altura de captação da amostra entre $2 m$ e $7 m$, são consideradas representativas de microescala. A captação das amostras de material particulado nas redes de avaliação da CETESB se dá numa faixa de altura de 3 a 4 metros" (CETESB, 2013d, p. 3).

Estes critérios foram adotados para avaliar as escalas de representatividade das estações da CETESB. Em alguns casos, foram necessárias análises mais aprofundadas como a avaliação das concentrações medidas em função de direção e velocidade dos ventos; comparação dos resultados de concentração com os dados obtidos em outras estações localizadas na mesma região; avaliação da composição do material particulado visando estimar se é significativa a contribuição da fonte veicular, por emissão direta ou pela ressuspensão da poeira de rua. Como conclusão deste relatório, tem-se que as três estações de Cubatão foram classificadas como não microescala, concluindo-se que o tráfego não impacta na estação (CETESB, 2013d).

\section{- $\quad$ Resultados de monitoramento da rede automática}

A CETESB utiliza uma rede de monitoramento automática que registra as principais ocorrências e observações ao longo do período de monitoramento, de forma a auxiliar a interpretação de tendência de longo prazo (CETESB, 2012 b5). Em Cubatão, as ações de controle de poluição industrial e as outras medidas adotadas no Plano de Controle de 
Poluição Ambiental surtiram o efeito desejado, ainda que não em sua totalidade (CETESB, 2012b ${ }^{5}$; FERREIRA, 2007). Seguem-se no quadro 5 e nas figuras 21, 22 e 23, os resultados registrados ao longo dos anos em que ocorreu este monitoramento da qualidade do ar, considerando o parâmetro Material Particulado $\left(\mathrm{MP}_{10}\right)$.

Destacou-se em negrito no Quadro 5, os períodos em que os estados de "Alerta” e/ou “Emergência” deixaram de ocorrer na região.

Quadro 5: Número de estados de Atenção, Alerta e Emergência declarados em Vila Parisi (1986 -2002), com destaque em negrito para o período em que não ocorreram estados de "Alerta” e/ou "Emergência”

\begin{tabular}{|c|c|c|c|}
\hline Ano & Atenção & Alerta & Emergência \\
\hline 1986 & 66 & 1 & 0 \\
\hline 1987 & 51 & 4 & 0 \\
\hline 1988 & 37 & 3 & 0 \\
\hline 1989 & 15 & 0 & 0 \\
\hline 1990 & 5 & 1 & 0 \\
\hline 1991 & 31 & 2 & 1 \\
\hline 1992 & 1 & 0 & 0 \\
\hline 1993 & 12 & 0 & 0 \\
\hline 1994 & 57 & 1 & 1 \\
\hline 1995 & 34 & 0 & $\mathbf{0}$ \\
\hline 1996 & 0 & 0 & 0 \\
\hline 1997 & 3 & $\mathbf{0}$ & $\mathbf{0}$ \\
\hline 1998 & $\mathbf{0}$ & $\mathbf{0}$ & $\mathbf{0}$ \\
\hline 1999 & $\mathbf{0}$ & $\mathbf{0}$ & $\mathbf{0}$ \\
\hline 2000 & $\mathbf{0}$ & 0 & $\mathbf{0}$ \\
\hline 2001 & 1 & $\mathbf{0}$ & $\mathbf{0}$ \\
\hline 2002 & $\mathbf{0}$ & $\mathbf{0}$ & $\mathbf{0}$ \\
\hline
\end{tabular}

Fonte: CETESB, $2002 a^{12}$, p. 03 (Modificado)

Nas figuras 21e 22 também pode ser observado dos resultados de monitoramento, que no período de 2003 a 2012 também não foram registrados estados de "Alerta” e/ou "Emergência".

\footnotetext{
${ }^{12}$ CETESB - Relatório da Qualidade do Ar - 2002 - referenciado como "CETESB - serie a Relatórios da Qualidade do Ar - 1985 a 2013”
} 
Figura 21: $\mathbf{M P}_{10}$ - Distribuição percentual da qualidade do ar - Cubatão - V. Parisi, Rede automática (maio a setembro)

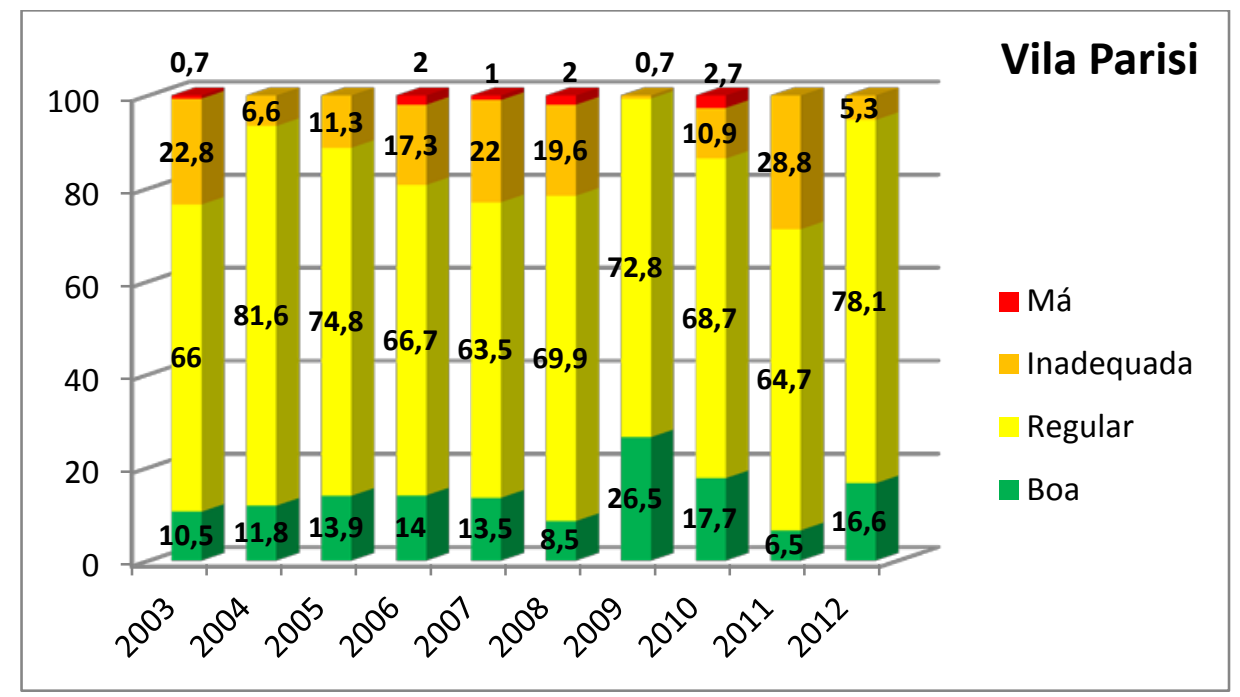

Fonte: CETESB, $2012 b^{5}$, p. 23(Modificado)

Em 2005, foi instalada uma nova estação medidora para monitoramento dos parâmetros da qualidade do ar na região do Vale do Mogi, denominada Cubatão - V. Mogi. Os dados registrados por ela passaram a ser validados a partir de 2006. Na figura 22, segue o histórico de dados referente a essa estação, para o parâmetro Material Particulado $\mathrm{MP}_{10}$, durante a operação inverno (maio-setembro), no período de 2006 a 2012.

Figura 22: $\mathbf{M P}_{10}$ - Distribuição percentual da qualidade do ar - Cubatão - V. Mogi, Rede automática (maio a setembro)

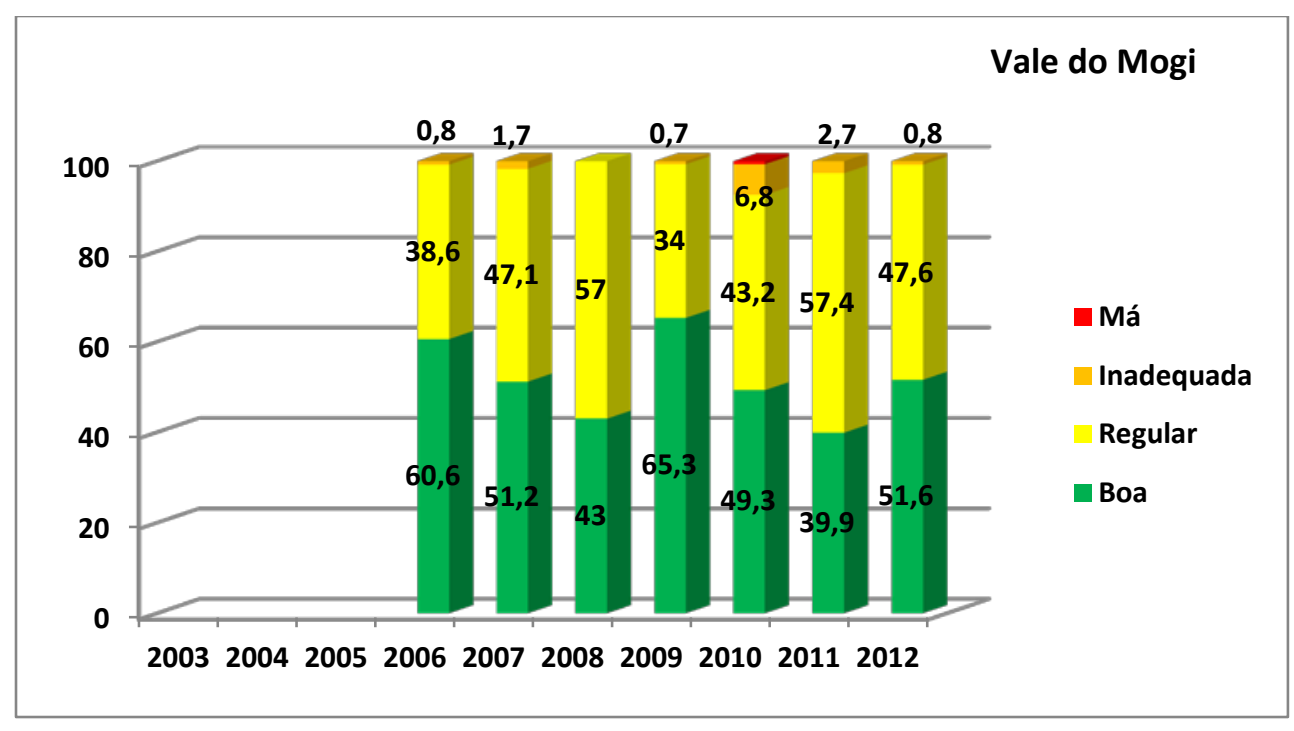

Fonte: CETESB, $2012 b^{5}$, p. 23(Modificado) 
Da mesma forma que nas demais estações medidoras de Cubatão, a unidade V. Mogi segue os mesmos critérios para estabelecimento de episódios críticos de poluição do ar, identificando, portanto, que não houve ocorrências de estados de "Alerta" ou "Emergência” neste período, porém observou-se que um aumento do percentual de índice de qualidade do ar “Inadequada” e “Má” vem ocorrendo a partir de 2010.

Os dados de monitoramento coincidem com o aumento das atividades na região do Vale do Mogi, como obras de ampliação de pátios e instalação de novas empresas. Em contrapartida, as ações preventivas e de fiscalização também foram incrementadas, o que demonstrou uma melhora em 2012.

Já na área urbana, região onde a população encontra-se a cerca de $10 \mathrm{~km}$ da estação de V. Parisi, no Polo industrial (VALARINI, 2011), a qualidade do ar medida na estação Cubatão-Centro, apresenta índices de qualidade do ar "BOA” em grande parte do tempo (Figura 23).

"É importante ressaltar que as altas concentrações em Cubatão são observadas, quase que, exclusivamente, na região industrial, uma vez que os níveis de concentração dos poluentes monitorados permanentemente na região central de Cubatão são mais baixos que os observados na maioria das estações da RMSP, exceção feita ao ozônio. As concentrações de ozônio na estação Cubatão-Centro ultrapassam o padrão de qualidade do ar e aproximam-se dos níveis da RMSP" CETESB, 2002a ${ }^{10}$, p. 2).

Figura 23: $\mathbf{M P}_{10}$ - Distribuição percentual da qualidade do ar - Cubatão - Centro, Rede automática (maio a setembro)

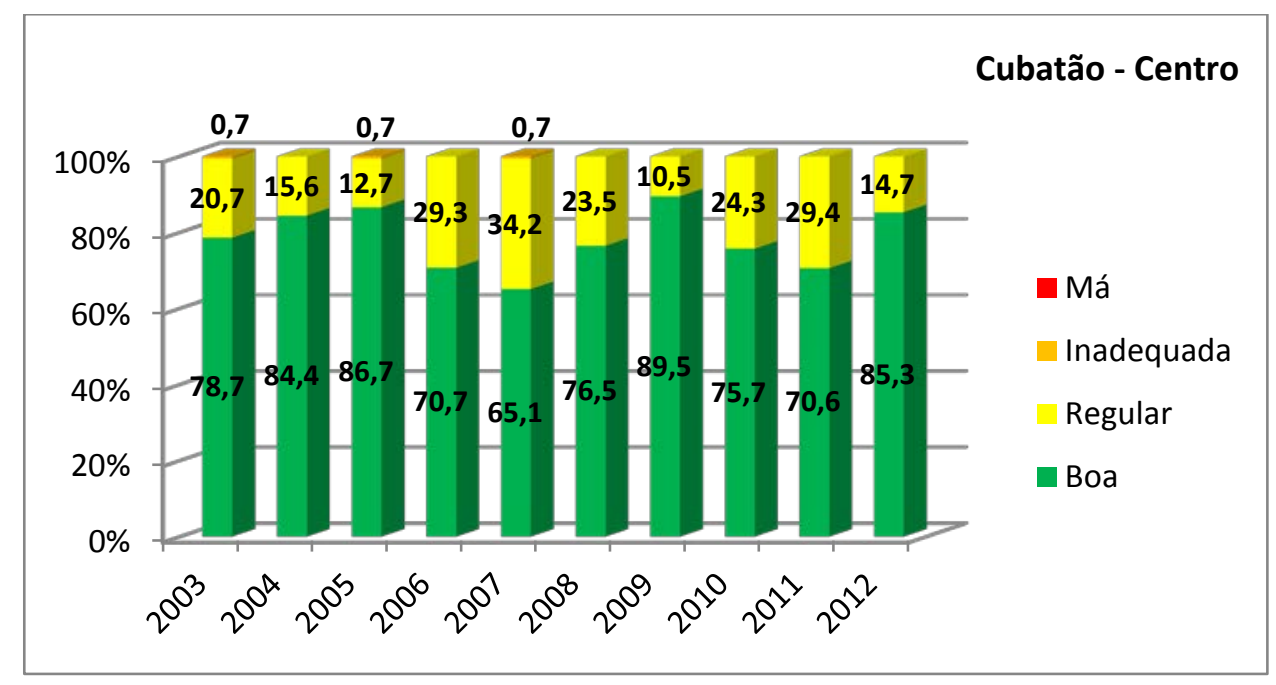

Fonte: CETESB, $2012 b^{5}$, p. 22(Modificado) 
Com base nestes dados, observa-se que as ações de controle de poluição industrial e outras medidas adotadas no Plano de Controle de Poluição Ambiental surtiram o efeito desejado, ainda que não em sua totalidade (CETESB, 2012b5; FERREIRA, 2007). Este efeito observa-se principalmente com a reversão de episódios críticos de poluição do ar, não havendo registros de estados de “Alerta” ou "Emergência”, desde 1995.

\subsection{4 - Gestão da qualidade do ar}

\section{- Plano de ações de controle de poluição}

No Estado de São Paulo, foram estabelecidos e implantados os programas de controle de poluição do ar, por meio da Lei Estadual n ${ }^{\circ}$ 997, de 31 de maio de 1976 e o Decreto Estadual $\mathrm{n}^{0}$ 8.468, de 08 de setembro de 1976, que a regulamenta, com padrões e critérios definidos para a gestão ambiental.

No nível federal, foram promulgadas leis visando o controle da poluição do ar. Entre elas, destaca-se a Resolução CONAMA no 005, de 15 de junho de 1989, que instituiu o Programa Nacional de Controle da Qualidade do Ar - PRONAR, como um dos instrumentos básicos da gestão ambiental para proteção da saúde e bem estar das populações e melhoria da qualidade de vida com o objetivo de permitir o desenvolvimento econômico e social do país de forma ambientalmente segura, pela limitação dos níveis de emissão de poluentes por fontes de poluição atmosférica. Também foi estabelecido por meio da Resolução CONAMA nº 018/86, o PROCONVE - Programa de controle da poluição do ar por veículos automotores (automóveis). Estes programas objetivaram a fixação de prazos, limites máximos de emissão e, para controle de emissões de veículos, o estabelecimento de exigências tecnológicas para veículos automotores, nacionais e importados (CETESB, 2012b $b^{5}$ ).

Os casos de problemas com a saúde da população exposta à poluição e a constante divulgação em mídia foram os principais motivos que levaram à adoção de ações de gestão para controle da poluição de uma forma mais contundente, abrangendo a qualidade do ar, das águas, do solo e da vegetação, culminando, em 1983, com a criação do Plano de Controle da Poluição Ambiental em Cubatão, sendo a CETESB Companhia de Tecnologia de Saneamento Ambiental, incumbida por sua implantação. Este Plano de Controle da Poluição Ambiental foi subdividido em partes, de forma a prover recursos para enfrentar os problemas a partir de critérios de priorização estabelecidos pelo Governo (FERREIRA, 2007).

Conforme descreveu a autora, a implantação do Plano de Controle de Poluição Ambiental em Cubatão teve como objetivo adotar ações corretivas visando redução das emissões de poluentes de ar e de outros poluentes das fontes do complexo industrial de Cubatão e adotar medidas preventivas, como a proibição de implantação de novas fontes de poluição ou alteração/aumento de produção que pudessem acarretar aumento das emissões existentes. Para isso, foi realizado levantamento da situação das fontes de poluição industrial, sua caracterização, enquadramento legal para prioridade de controle, 
obtenção de registro e licenças de funcionamento das empresas do Polo, apresentação de planos de controle de poluição para cada fonte poluidora, e implantação dos Planos de Ação de Emergência, para atender a episódios agudos de poluição do ar. Houve também ações direcionadas a apoio técnico, com o incentivo a pesquisas, para subsidiar o estabelecimento de critérios para alteração da legislação de zoneamento industrial e uso do solo na região; e com ações direcionadas à educação ambiental da população do município, visando a participação organizada no equacionamento desses problemas (FERREIRA, 2007).

Com o objetivo de reduzir a poluição das emissões de Cubatão em níveis aceitáveis, foi implantado um programa para controle da poluição industrial no prazo de cinco anos. Conforme descrito no relatório de qualidade do ar do Estado de São Paulo, de 2010, “As indústrias de Cubatão foram então mobilizadas em um abrangente esforço de redução e monitoramento da poluição. Como consequência, já em 1984, 62 cronogramas de atividades de controle foram estabelecidos entre indústrias e CETESB com vistas à redução da poluição atmosférica” (CETESB a, 2010, p. 131).

Em cada um dos cronogramas, foram especificados equipamentos, instalações e procedimentos de produção para que cada fonte atendesse aos padrões estabelecidos. "De 1984 a 1994, foram investidos cerca de 700 milhões de dólares por parte das industrias no controle da poluição ambiental, com resultados altamente positivos, levando a uma reversão do quadro de poluição” (CETESB a, 2010, p. 131).

Mesmo com ações importantes de gestão e de, comprovadamente, ter havido reversão da situação ambiental crítica (CETESB, 2012a ${ }^{4}$; CETESB, 2012b ${ }^{5}$; FERREIRA, 2007; VALARINI, 2011), com o reconhecimento de "Cidade símbolo da recuperação ambiental” e a outorga, pela ONU, do selo verde, durante a ECO 92 (PIRES, 2012), o estigma do "Vale da Morte” ainda existe em Cubatão.

Desta forma, fica claro que o sério problema ambiental ocorrido em Cubatão foi a "mola propulsora” para que ações de gestão e políticas públicas fossem adotadas, visando o controle e equacionamento da situação. O esforço necessário para que o Plano de Ação para Controle da Poluição em Cubatão fosse exitoso, dependeu da interação e comprometimento de todos os atores envolvidos, quais sejam, Governo Federal, Estadual, Municipal, sociedade civil, técnicos especialistas, pesquisadores, imprensa e igreja.

Na análise da evolução da qualidade do ar em 2013, conforme descrito no relatório de qualidade do ar do Estado de São Paulo (CETESB, $2013 \mathrm{a}^{15}$ ), a qualidade do ar em Cubatão permanece determinada, principalmente, por fontes industriais, caracterizando um problema totalmente diferente dos grandes centros urbanos. As altas concentrações de poluentes em Cubatão são observadas, na área industrial. Reconhece-se que o equacionamento da situação está encaminhado e os planos de controle se encontram consolidados. 
O problema de poluição do ar em Cubatão, a despeito de sua complexidade, tem seu equacionamento encaminhado e parte dos planos de controle já foi consolidada. Além da ênfase ao cumprimento das metas de controle estabelecidas, deve-se ressaltar que foi estabelecido um programa de manutenção das reduções obtidas. Dada a grande quantidade de equipamentos de controle instalados, é de fundamental importância um programa de vigilância das condições de seu funcionamento, uma vez que tão importante quanto à instalação do sistema de controle é a sua operação e manutenção adequadas(CETESB, 2013a ${ }^{10}$, p. 15).

\section{- Plano de ações de emergência - episódios críticos}

O conjunto de ações para controle dos episódios críticos foi proposto no Decreto Estadual n 8.468/76, denominado “Operação Inverno”. Seu objetivo é proteger a saúde da população contra os agravos causados por episódios agudos de poluição do ar na Região Metropolitana de São Paulo - RMSP e Cubatão (CETESB, 2012b ${ }^{5}$, p. 01).

É previsto pela CETESB que, em casos de episódios críticos de poluição do ar, como a declaração de estados de alerta ou emergência, um plano de emergência para a redução das emissões deve ser acionado até que as concentrações de partículas alcancem níveis normais (média 24 horas) (CETESB, 2002a ${ }^{10}, 2012 \mathrm{a}^{4}$ ). Essas ações de controle são adotadas principalmente junto às indústrias alocadas no Polo Industrial e variam de empresa para empresa, conforme os processos produtivos e critérios de manutenção dos equipamentos. As ações comumente adotadas são a redução de produção, a paralisação de determinados equipamentos de processos e, para os casos de declaração de estado de emergência, é prevista a paralisação da maioria dos processos e atividades da indústria (CIESP, 2013a).

Com a evolução das ações implantadas de acordo com o Plano de Ações de Controle de Poluição de Cubatão, que teve por foco, em sua maioria, ações voltadas para o controle da poluição industrial, tiveram como resultado reduções significativas das emissões industriais. Na década de 1990, os resultados positivos dos investimentos e controle fizeram-se sentir na região do Polo industrial, sendo retratados nos índices de material particulado medidos nas estações, principalmente, na estação da Vila Parisi.

Com a implantação do terminal de cargas no Polo Industrial, houve o aumento da circulação de caminhões, principalmente no entorno da estação medidora da Vila Parisi, identificando-se influência da ressuspensão da poeira das vias, nos índices monitorados. A partir da observação desta nova tendência, como ação preventiva, o CIESP Cubatão, em conjunto com a CETESB, implantou um plano de ação para evitar a ressuspensão de poeira das vias de acesso ao Polo industrial, realizado anualmente até os dias atuais, no período do inverno, entre os meses de maio a setembro. O plano de ações preventivas para evitar episódios críticos de poluição do ar consiste na realização 
da limpeza e umectação das vias e com um sistema de comunicação permanente entre CETESB e as empresas, por 24 horas, de forma que, ao se verificar que o padrão horário de material particulado $\mathrm{MP}_{10}$ atingiu a concentração de $150 \mu \mathrm{g} / \mathrm{m}^{3}$, são disparadas comunicações às empresas do Polo e acionados os caminhões para intensificação da umectação (Figuras 24 e 25). Com esta ação preventiva, que visa minimizar a ressuspensão de poeira devido à movimentação de veículos, em conjunto com a manutenção da fiscalização e controle das emissões de fontes fixas no polo industrial, não ocorrem episódios críticos de poluição do ar desde 1995.

Figura 24 - Atividades de umectação das pistas com caminhão pipa (24 horas)

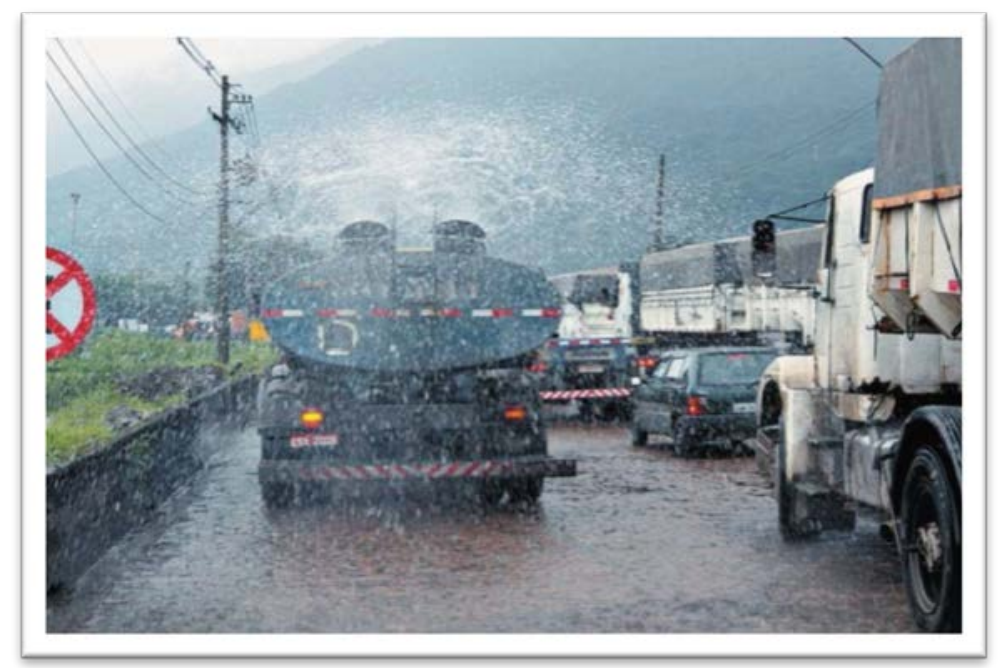

Fonte: CIESP, $2013 b$.

Figura 25 - Atividades de varrição das pistas nas vias de acesso ao Polo Industrial.

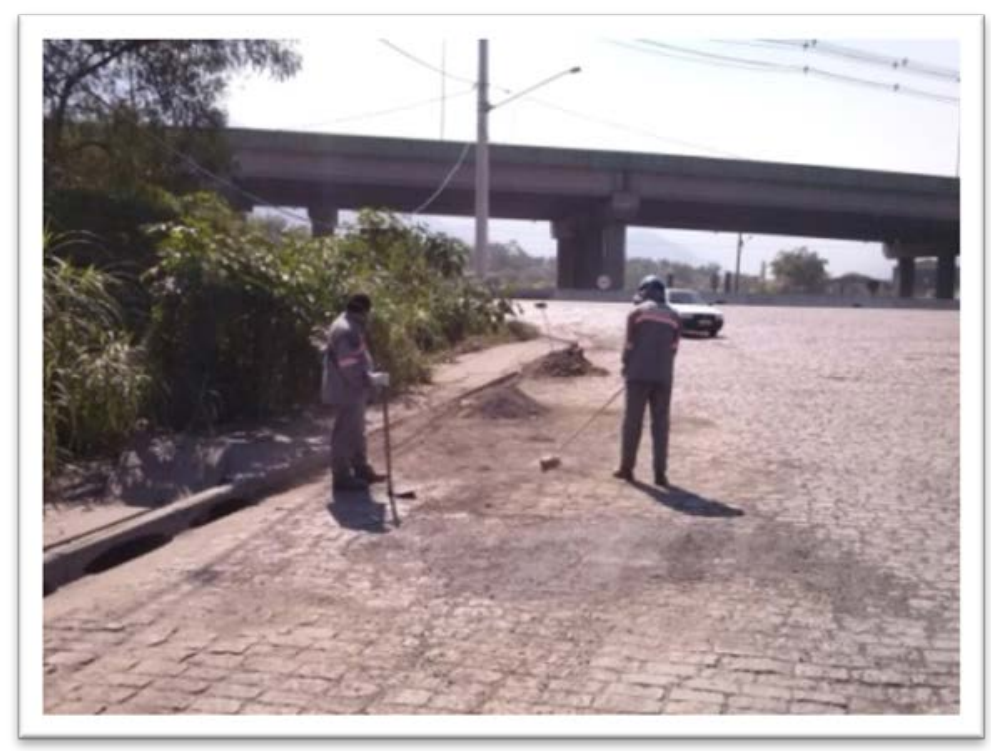

Fonte: CIESP, $2013 \mathrm{~b}$. 
Em 2013, as ações preventivas de limpeza e umectação removeram mais de 100 toneladas de poeira das vias de tráfego do polo industrial.

Porém, o excesso de caminhões nos últimos anos vem afetando a região do Polo Industrial de Cubatão, acarretando o aumento do tráfego e os congestionamentos.

Durante a operação inverno de 2013, houve dificuldades de circulação do caminhãopipa nos momentos de trânsito intenso. Houve trechos que ficaram impedidos de acesso pelas vias estarem sendo usadas como estacionamento de caminhões, mesmo com a atuação da Companhia Municipal de Trânsito de Cubatão (CMT) e da Polícia Militar Rodoviária (CIESP, 2013b). O excesso de circulação no entorno da estação medidora da Vila Parisi e os congestionamentos nas estradas, não só propiciam maior ressuspensão de poeira, podendo influenciar os valores de concentrações de $\mathrm{MP}_{10}$, como também dificultam as atividades de limpeza e umectação.

As ações de gestão da CETESB junto aos pátios de caminhões são normalmente corretivas. As ações preventivas, como as exigências para a umectação e pavimentação das destes pátios, são feitas quando do licenciamento destes pátios. Porém, este instrumento legal não pode ser utilizado para todos os pátios, uma vez que nem todos (dependendo das atividades áreas internas exercidas) são passíveis de licenciamento. Apenas os que possuem serviços de apoio passíveis de licenciamento, como restaurantes, por exemplo, são licenciáveis. Estes possuem a exigência formal de prover e assegurar a umectação das áreas internas e, em alguns casos, exigência de pavimentação destas vias, visando minimizar a ressuspensão de poeiras. Os pátios que não são passíveis de licenciamento podem ser autuados, porém estas medidas corretivas, não apresentam o resultado no "timing” necessário.

Foi identificado, em relatórios de qualidade do ar emitidos pela CETESB, que há alteração do cenário da região do Polo industrial de Cubatão, com a inserção de outras atividades que concorrem na emissão de material particulado (poeira).

Observou-se que ações voltadas a controle das emissões veiculares foram adotadas, visando a redução dos episódios críticos de poluição do ar na RMSP, porém em Cubatão, não houve alteração quanto à definição das ações de controle, mantendo-se a situação anterior, ou seja as ações concentradas apenas nas instalações industriais, mesmo com a identificação ao longo dos anos de que há um aumento da circulação de veículos na região, podendo estar influenciando nas estações medidoras da qualidade do ar. (CETESB, 2005a ${ }^{13}$, p. 45; CETESB, 2007a ${ }^{14}$, p.133).

Necessita-se na região um plano de ações preventivas, que seja “costurado” a várias mãos, contando com atores como a Prefeitura Municipal de Cubatão, as indústrias, CETESB, Pátios de caminhões e ônibus, ECOVIAS, Polícia Militar, Polícia Militar Rodoviária e, até mesmo, o Porto de Santos, para que as medidas sejam discutidas,

\footnotetext{
${ }^{13}$ CETESB - Relatório da Qualidade do Ar - 2005 - referenciado como "CETESB - serie a Relatórios da Qualidade do Ar - 2001 a 2013”

${ }^{14}$ CETESB - Relatório da Qualidade do Ar - 2007 - referenciado como "CETESB - serie a Relatórios da Qualidade do Ar - 2001 a 2013”
} 
definidas responsabilidades, orçamentos e prazos para implantação, com revisões periódicas das ações adotadas, de forma a “colher os frutos” a tempo de se antecipar ao caos.

\subsection{5 - Novos padrões de qualidade do ar}

Em 2013, por meio do Decreto Estadual n ${ }^{0} 59.113$, de 23/04/2013, foram estabelecidos novos padrões de qualidade do ar para o Estado de São Paulo, tendo por base as diretrizes estabelecidas pela Organização Mundial da Saúde (OMS). Este novo decreto preconiza que:

“A administração da qualidade do ar no território do Estado de São Paulo será efetuada por meio de Padrões de Qualidade do Ar, observados os seguintes critérios: I. Metas Intermediárias - (MI) estabelecidas como valores temporários a serem cumpridos em etapas, visando à melhoria gradativa da qualidade do ar no Estado de São Paulo, baseada na busca pela redução das emissões de fontes fixas e móveis, em linha com os princípios do desenvolvimento sustentável; II. Padrões Finais (PF) - Padrões determinados pelo melhor conhecimento científico para que a saúde da população seja preservada ao máximo em relação aos danos causados pela poluição atmosférica” (CETESB, 2014a).

O Quadro 6 apresenta os novos padrões de qualidade do ar estabelecidos, sendo destacados aqueles para o parâmetro material particulado $\mathrm{MP}_{10}$.

Quadro 6: Padrões Estaduais de Qualidade do Ar (Decreto Estadual $n^{\circ} 59.113$ de 23/04/2013) com destaque para o parâmetro $M P_{10}$

\begin{tabular}{|l|l|l|l|l|l|l|}
\hline Poluente & $\begin{array}{l}\text { Tempo de } \\
\text { Amostragem }\end{array}$ & $\begin{array}{l}\text { MI } \\
\left(\boldsymbol{\mu g} / \mathbf{m}^{3}\right)\end{array}$ & $\mathbf{1}$ & $\begin{array}{l}\text { MI } \\
\left(\boldsymbol{\mu g} / \mathbf{m}^{3}\right)\end{array}$ & $\begin{array}{l}\text { MI } \\
\left(\boldsymbol{\mu g} / \mathbf{m}^{3}\right)\end{array}$ & $\begin{array}{l}\mathbf{P F} \\
\left(\boldsymbol{\mu g} / \mathbf{m}^{3}\right)\end{array}$ \\
\hline $\begin{array}{l}\text { Partículas } \\
\text { inaláveis } \\
\left(\mathrm{MP}_{10}\right)\end{array}$ & 24 horas & 120 & 100 & 75 & 50 \\
\hline
\end{tabular}

MAA - média aritmética anual

Fonte: CETESB, 2014a, p.15 
O Decreto Estadual $n^{\circ}$ 59.113, de 23/04/2013 prevê que as metas Intermediárias devem ser atendidas em 3 (três) etapas, assim determinadas:

I. Meta Intermediária Etapa 1 - (MI1) - Valores de concentração de poluentes atmosféricos que devem ser respeitados a partir de 24/04/2013;

II. Meta Intermediária Etapa 2 - (MI2) - Valores de concentração de poluentes atmosféricos que devem ser respeitados subsequentemente à MI1, que entrará em vigor após avaliações realizadas na Etapa 1, reveladas por estudos técnicos apresentados pelo órgão ambiental estadual, convalidados pelo CONSEMA;

III. Meta Intermediária Etapa 3 - (MI3) - Valores de concentração de poluentes atmosféricos que devem ser respeitados nos anos subsequentes à MI2, sendo que o seu prazo de duração será definido pelo CONSEMA, a partir do início da sua vigência, com base nas avaliações realizadas na Etapa 2.

- Monitoramento 2013 - os novos padrões de qualidade do ar

Os resultados do monitoramento da qualidade do ar no Estado de São Paulo, em 2013, foram analisados já considerando os novos padrões estaduais de qualidade do ar estabelecidos pelo Decreto Estadual n ${ }^{\circ}$ 59.113, de 23/04/2013.

Para os fins desta pesquisa identificou-se que numa comparação dos resultados de monitoramento da qualidade do ar, tomando-se por base o parâmetro material particulado, entre a RMSP e Cubatão, ficou clara a distinção das ações a serem previstas para a gestão da qualidade do ar, reforçando a ideia proposta de se desenvolver uma nova abordagem para a adoção de ações para a gestão da qualidade do ar.

No relatório de qualidade do ar, emitido pela CETESB, em 2014, na conclusão geral para a RMSP, os problemas de qualidade do ar ocorrem principalmente em função das emissões veiculares, e foram adotadas como principais medidas de controle, a inspeção veicular, a intensificação da fiscalização e o recolhimento dos veículos sem condições de uso. Para a RMSP, foi identificada a necessidade de adoção de medidas complementares que viabilizem a redução do número de viagens e dos congestionamentos, como o aumento da eficiência do sistema viário e da oferta de transporte público, além do planejamento do uso do solo. Ainda segundo este relatório, em Cubatão, a principal fonte de emissões é a industrial, e como medidas adotadas estas focam principalmente no programa de manutenção da redução das emissões destas fontes (CETESB, 2013a ${ }^{15}$ ).

“O problema de poluição do ar em Cubatão, a despeito de sua complexidade, tem seu equacionamento encaminhado e parte dos planos de controle já foi consolidada. Além da ênfase ao 
cumprimento das metas de controle estabelecidas, deve-se ressaltar que foi estabelecido um programa de manutenção das reduções obtidas. Dada a grande quantidade de equipamentos de controle instalados, é de fundamental importância um programa de vigilância das condições de seu funcionamento, uma vez que tão importante quanto à instalação do sistema de controle é a sua operação e manutenção adequadas" (CETESB, 2013a $a^{15}$, p. 15).

\subsection{6 - Considerações sobre o item}

Observando o que foi descrito neste item, os planos de ação adotados tanto para a gestão da qualidade do ar para controle da poluição, quanto à gestão de qualidade do ar em casos de ocorrência de episódios críticos, são similares ao longo dos anos, diferenciando-se na intensidade das ações, conforme os resultados de monitoramento registrados apontam a necessidade de reforço no controle das emissões. As ações de controle de emissões atmosféricas normalmente implantadas em Cubatão convergem para as fontes fixas, que no caso do Polo Industrial representa a maior fonte de contribuição.

As fontes móveis são consideradas como fontes de emissão atmosférica e planos de ação para controle destas emissões foram instituídos pelos órgãos de controle ambiental. Porém observa-se que as ações de controle associadas a estas fontes, são normalmente referentes às emissões diretas da combustão dos veículos, por meio de melhorias tecnológicas, substituição de frota ou intensificação da fiscalização.

Para a realidade de Cubatão, destaca-se que a partir de 1995, com o incremento da circulação de veículos nas proximidades da estação medidora da Vila Parisi, viu-se a necessidade de adotar medidas complementares como ações preventivas. Essas ações foram positivas e contribuíram no controle da qualidade do ar do Polo industrial constituindo-se primordialmente em controle da ressuspensão de poeiras no entorno das vias próximas às estações medidoras.

Um fator relevante desta pesquisa refere-se à localização das estações medidoras de qualidade do ar implantadas pela CETESB, na década de 1980, que teve sua rede concebida de forma a considerar as concentrações representativas das áreas de maior densidade populacional, o impacto ao meio ambiente devido a determinadas fontes ou grupo de fontes e os níveis médios de concentração de poluentes na atmosfera para a região (CETESB, $2013 \mathrm{~d}$ ).

Percebe-se, que a vocação da região, antes exclusivamente industrial, passou a agregar uma nova atividade de caráter relevante, que em uma região como o Polo de Cubatão,

\footnotetext{
${ }^{15}$ CETESB - Relatório da Qualidade do Ar - 2013 - referenciado como "CETESB - serie a Relatórios da Qualidade do Ar - 1985 a 2013”
} 
concorre com a atividade industrial em vários aspectos como, por exemplo, trânsito e emissões atmosféricas. Para esta pesquisa, considerou-se o potencial de contribuição das emissões ocasionadas pelo aumento da circulação de veículos no Polo industrial, principalmente por emissões fugitivas, oriundas da ressuspensão da poeira, decorrente da movimentação destes veículos.

Conforme Ferreira (2007), a gestão ambiental em um município como Cubatão, com o histórico de poluição pesando sobre os gestores públicos (municipais, estaduais e federais) é muito complexa. Há necessidade de uma integração entre os setores governamental, empresarial e sociedade civil, bem como a atualização de políticas públicas, para que ações eficazes para gestão ambiental sejam adotadas.

Com base nos capítulos anteriores desta pesquisa, considerando a gestão ambiental de emissões atmosféricas, e consequentes melhorias para a qualidade do ar, identificou-se que as diretrizes de governo associadas aos interesses de desenvolvimento, acarretaram as mudanças na região, porém não se verificou no planejamento das políticas públicas, a revisão das ações de fiscalização e controle para alinhar a gestão ambiental, considerando as necessidades de desenvolvimento econômico e eventuais mudanças.

Sendo assim, a percepção que norteia esta pesquisa é que as ações de gestão ambiental não consideraram de forma efetiva a alteração da dinâmica da região, e que novos problemas vêm sendo acrescidos ou substituídos a problemas equacionados.

Reforça-se, no entanto, que não se pretende afirmar que não haja contribuição das emissões industriais nos índices de material particulado monitorados nas estações medidoras do Polo industrial de Cubatão, sabendo-se que as principais fontes de emissão de material particulado ainda são as fontes fixas. Porém, o foco é que as alterações da dinâmica ocorreram e as ações adotadas para mitigar os efeitos da ressuspensão de poeiras no entorno das estações, não foram adotadas de forma sistêmica com a utilização de uma rotina de avaliação das necessidades da região. Apesar das emissões veiculares e de emissões fugitivas não serem significativas se comparadas ao volume potencial de emissão, estas não devem ser ignoradas quando do processo de decisão para adoção de medidas corretivas ou preventivas, uma vez que o grande fluxo dos veículos é estabelecido ao lado das estações medidoras.

Outro fato a ser considerado também é que, com a publicação do Decreto Estadual 59.113, de 24/04/2013, que estabeleceu padrões de qualidade do ar mais restritivos, cabe analisar, como esta nova determinação legal pode influenciar nas ações de gestão para o controle de poluição do ar.

Estas considerações levam ao questionamento: os critérios e ações já consolidadas ainda são pertinentes para o cenário atual? Que possíveis elementos-chave poderiam ser definidos para que sejam utilizados em uma proposta de ferramenta de gestão ambiental que possibilite que novos cenários e tendências sejam sinalizados de uma forma prática e que permitam uma periodicidade de análise. A partir desta questão, foi desenvolvido o próximo capítulo, no qual foram analisados os cenários existentes em Cubatão ao longo do tempo, suas transformações e os principais elementos-chave que poderão ser utilizados no desenvolvimento de ferramentas para auxílio na tomada de decisões em 
momentos em que as mudanças de cenários estão começando a serem percebidas. O processo de tomada de decisão no início das mudanças pode levar a um melhor controle da situação, com tempo hábil para desenvolver propostas de solução.

\section{CAPÍTULO 3 - RESULTADOS E DISCUSSÃO}

\subsection{IDENTIFICAÇÃO DE CENÁRIOS}

Com base nas informações históricas descritas, foi feita compilação, em períodos de tempo, de forma a visualizar os fatos mais marcantes que caracterizaram mudanças significativas em Cubatão (APÊNDICE A - Consolidação dos principais fatos históricos de Cubatão e consequências).

Analisando os fatos compilados no quadro constante do APÊNDICE A foi possível identificar os principais fatos de interesse para esta pesquisa. De forma a facilitar a visualização dos resultados, foi elaborado um sistema de símbolos para denotar a criticidade da condição do Município de Cubatão e entorno, e a intensidade com que as ações, alterações na dinâmica e consequências foram tomando forma no decorrer dos anos. A legenda adotada nas figuras 26 e 27 não representa valor ou escala, tendo como objetivo apenas permitir comparação visual entre cores e tamanhos para exemplificar a intensidade e criticidade da situação em um período específico. São "sinalizadores" de tendência para identificar os cenários de interesse para esta pesquisa.

Figura 26: Sistema de cores para demonstrar alterações das condições da região

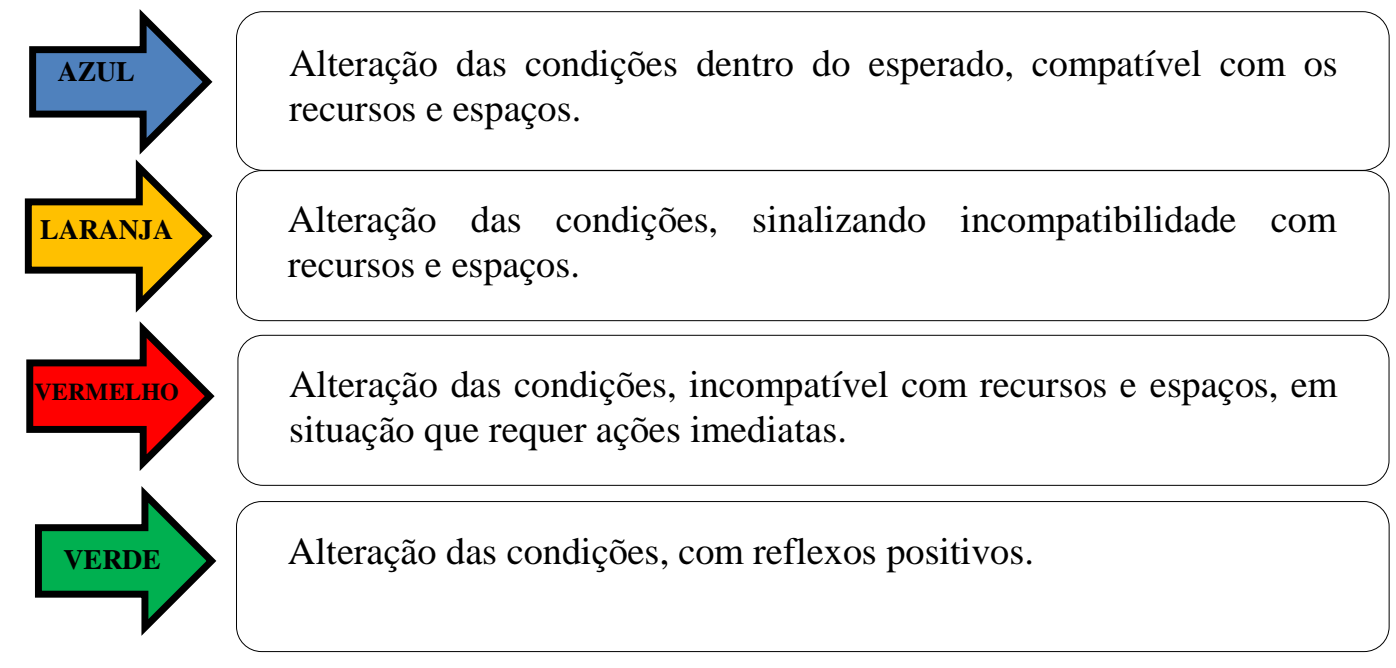

Fonte: elaboração própria 
Figura 27: Tamanho de setas para demonstrar a intensidade dos impactos identificados
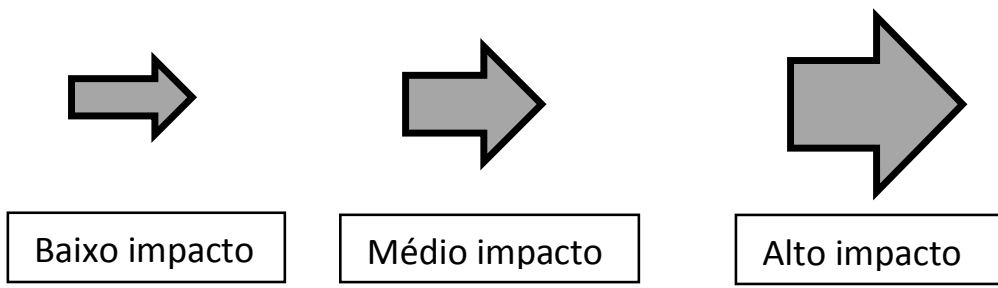

\section{Fonte: elaboração própria}

Como resultado da análise dos fatos compilados (APÊNDICE A) e utilizando o sistema de "sinalizadores" descritos (figuras 26 e 27) a criticidade de cada um dos períodos selecionados, foi comparada de forma a visualizar, os cenários delineados a cada período, permitindo desta forma, escolher aqueles de interesse para esta pesquisa.

A consolidação da criticidade da condição do Município de Cubatão e entorno, é demonstrada de forma simplificada (Quadro 7), considerando a intensidade das ações adotadas, as alterações da dinâmica e as consequências a cada período, com foco nas alterações na qualidade do ar. 
Quadro 7: Consolidação da criticidade dos cenários em Cubatão e entorno (continua)

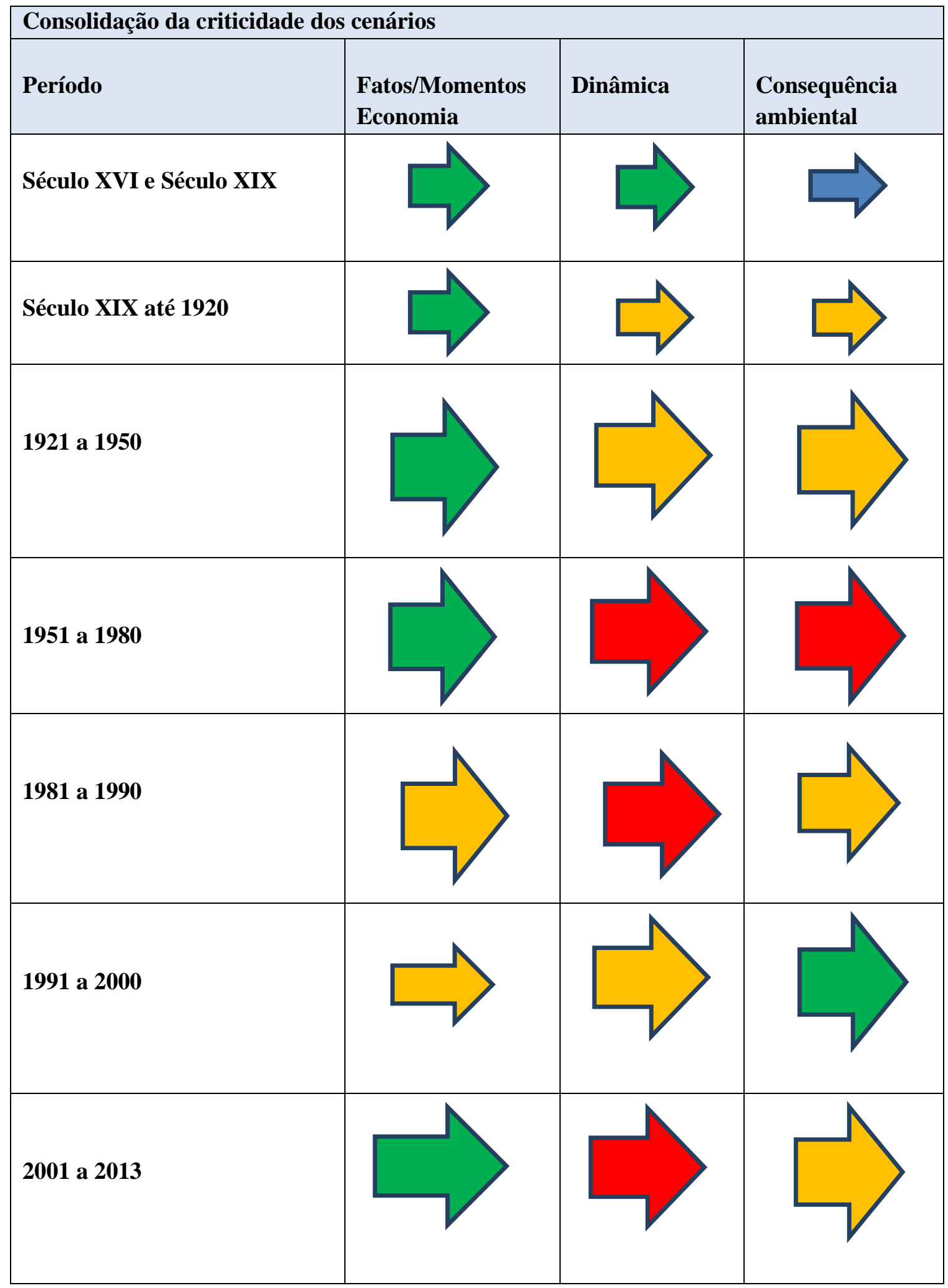

Fonte: elaboração própria 
Analisando os "sinalizadores" do Quadro 7 observa-se que as grandes alterações começaram a ocorrer a partir da industrialização, ou seja, a partir de 1921. Porém, de 1921 a 1950, as maiores consequências foram nas questões sociais e urbanas. Para fins desta pesquisa, o que norteia a delimitação dos cenários é a alteração da qualidade do ar. Portanto, os cenários passam a ser significativos quanto a este critério a partir de 1950, quando se iniciou a fase intensa de industrialização no Município. Considerou-se também o cenário até 2013, em função da identificação de novo ciclo de alteração da qualidade do ar, que pode estar relacionada à nova dinâmica da região.

Tendo em vista que no período de 1981 a 2000, houve evolução e estabilização da condição ambiental, foi adotado que este cenário poderia ser considerado único.

Sendo assim, ficaram delimitados três cenários, ou seja, os períodos de 1951 a 1980, no qual claramente foi verificado o impacto ambiental e início da reação para controle da poluição; 1981 a 2000, no qual houve efetivamente a reação e a recuperação ambiental e, 2001 a 2013 em que foi observada uma sinalização de que alterações da qualidade do ar vêm ocorrendo, com tendências a ficarem mais significativas em função da comparação dos índices com os novos padrões estabelecidos.

\subsection{ANÁLISE DE CENÁRIOS}

Para consolidação das informações na construção dos cenários, foram utilizadas figuras para visualizar as ações e reações ocorridas em cada período. São figuras ilustrativas e não há, neste momento, indicadores específicos que possibilitem traduzir com precisão estas ações e reações. O objetivo é contextualizar e visualizar os impactos observados e registrados ao longo do tempo e, com isso, descrever os elementos-chave identificados para o Município de Cubatão e entorno.

\subsubsection{Discussão do Cenário - 1951 - 1980}

O Município de Cubatão está intrinsicamente ligado à industrialização e ao plano de desenvolvimento industrial brasileiro. O cenário mundial consistia em um período pósguerra, ainda instável, com a chamada "Guerra fria”, com o País em crise econômica. As diretrizes de governo neste período foram voltadas ao desenvolvimento econômico, sob o regime de ditadura militar, visando a superação da crise e aumento da independência econômica do país. Cubatão foi escolhida então para a implantação do Polo Industrial, abrigando indústrias de base para alavancar o crescimento do País.

O principal motivo para ter sido inserida no Plano de Desenvolvimento Nacional (PND) foi a localização estratégica tanto do ponto de vista logístico (rodovias, ferrovias e Porto de Santos), quanto militar, quando considerada a localização geográfica, que com o Polo Industrial encravado entre as escarpas da Serra do Mar favorecia a proteção às indústrias de eventuais ataques ou atentados. Por motivo de Segurança Nacional, a gestão destas indústrias estava associada ao governo militar, sem abertura para que outros setores de administração pública pudessem atuar ou regular as suas atividades. 
Esta diretriz do Governo Federal teve uma consequência direta na ocupação da região. Esta ocorreu de forma desordenada, uma vez que, para atender à demanda do "boom" da construção das indústrias, foram atraídas pessoas, não só de Cubatão, mas de diversas regiões do país, que acabaram se instalando próximos aos canteiros de obras. $\mathrm{O}$ bairro da Vila Parisi foi um dos principais núcleos nesta fase, instalado sobre mangue, sem qualquer infraestrutura ou equipamentos municipais. Ao darem início à produção, as empresas necessitavam de mão de obra especializada. A maioria dos trabalhadores da etapa da construção foi dispensada ao fim das obras, por faltarem-lhes instrução ou especialização para o trabalho nas indústrias. Estes trabalhadores não voltaram às regiões de origem, ficando em Cubatão, ocupando-se de subempregos, e morando em áreas de mangue e encostas da Serra do Mar.

O desenvolvimento econômico acelerado que caracterizou este período levou a consequências ambientais significativas, em proporções tais que alcançaram conhecimento internacional. A poluição em Cubatão, em especial a poluição do ar, levou a consequências sérias para a comunidade, especialmente os moradores da Vila Parisi. Cubatão apresentou diversos problemas ambientais, devido à atividade industrial intensa, com controles ambientais incipientes, aliados a uma condição geográfica e climática desfavorável à dispersão da poluição. Devido à natureza das atividades industriais e das condições de dispersão na atmosfera, o material particulado (poeiras) foi o poluente que causou maior impacto na população, com alta incidência de casos de doenças cardiorrespiratórias. A poluição do ar afetou também a vegetação da Serra do Mar, que aliado às áreas ocupadas nas encostas, ocasionou o desbarrancamento, criando uma situação de emergência, que requereu respostas imediatas.

Com esse cenário delineado, a situação ficou insustentável, e o Governo Federal teve que adotar medidas urgentes e emergenciais para que o controle da poluição em Cubatão fosse equacionado. Este fato desencadeou no Estado de São Paulo, em 1976, a legislação específica para controle ambiental, sendo dada à CETESB a responsabilidade pelo controle ambiental no Estado.

Para Cubatão foi desenvolvido o "Plano de Ação para Controle da Poluição de Cubatão”, com diversas ações previstas nos âmbitos municipal e estadual, tendo como responsável pela sua implantação a CETESB.

O período de 1951 a 1980 foi ilustrado para que as interações entre os elementos pudessem ser retratadas e os impactos destas pudessem ser observados em um único cenário (Figura 28). 
Figura 28: Cenário 1951 - 1980 - Origem do problema - episódios críticos

\section{$\underline{1951-1980}$}

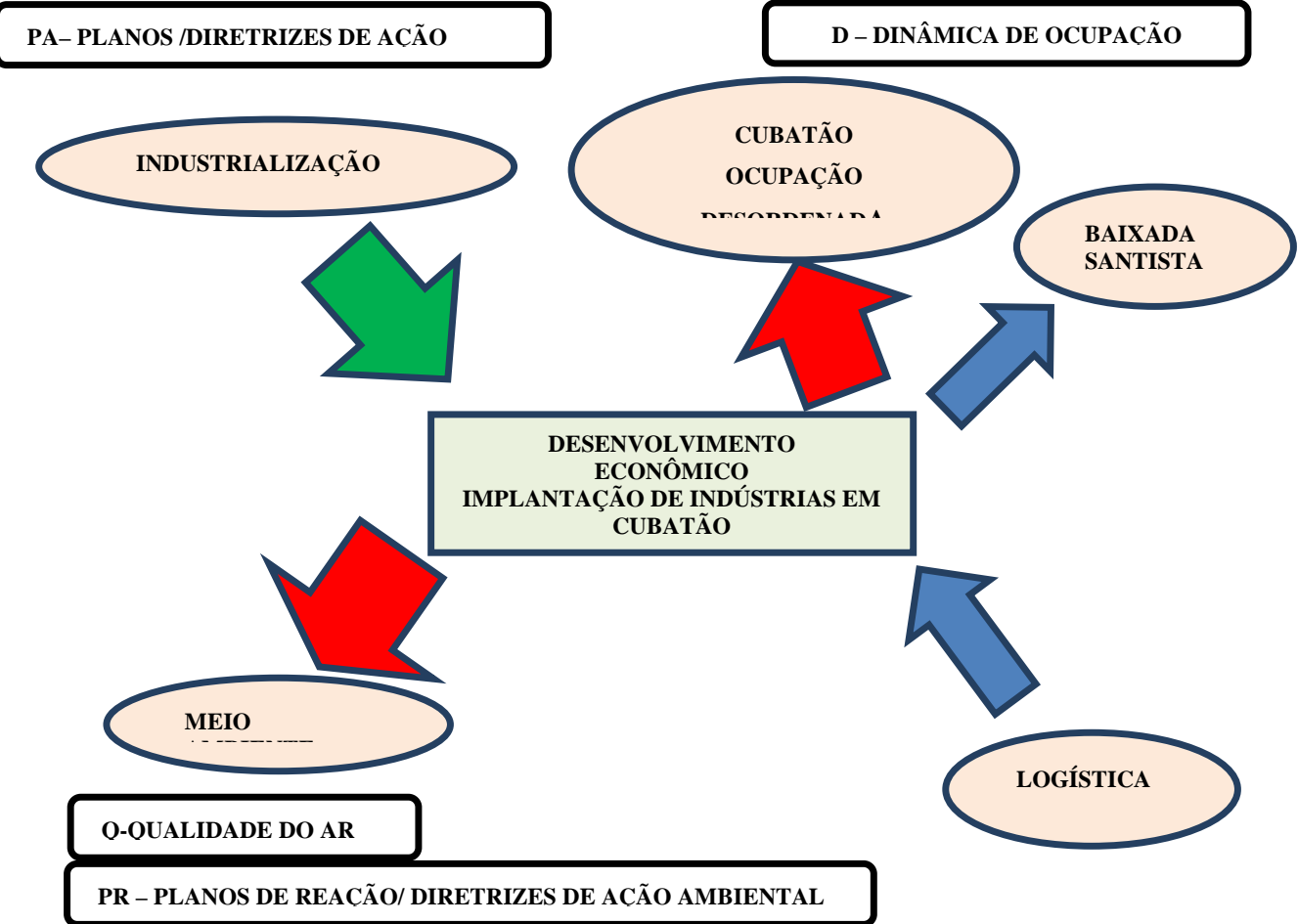

\section{Fonte: elaboração própria}

Na análise deste cenário de 1951 a 1980, tem-se que a diretriz de Governo Federal desenvolvida na região foi uma ação que trouxe como consequências, alterações significativas na dinâmica de ocupação e na qualidade do ar, levando a uma reação emergencial, qual seja o desenvolvimento do "Plano de ação para controle de poluição de Cubatão”.

\subsubsection{Discussão do Cenário - 1981 - 2000}

O ponto marcante, que definiu a mudança no cenário anterior foi a reação do Governo Federal, instituindo políticas para controle ambiental.

Para a análise do período de 1981 a 2000, consegue-se identificar os resultados obtidos deste esforço, caracterizando a interface entre os elementos, quais sejam os planos de ação/diretrizes do Governo Federal para o desenvolvimento do País, as consequências na dinâmica de ocupação e movimentação e na qualidade do ar, e os planos de reação, ou seja, as diretrizes de ação ambientais, em especial aquelas voltadas ao controle da qualidade do ar.

Neste período, no cenário mundial havia uma grave crise econômica (Crise do Petróleo) que, associada à crise já acentuada no País, sinalizava a necessidade de mudanças nas 
estratégias de governo. Porém, a decisão do Governo Federal à época foi manter os investimentos na indústria que, no final da década de 1980, com a crise e recessão do país, gerou cortes nos gastos públicos e restrições de importações, afetando significativamente as indústrias de Cubatão que eram, na maioria, administradas pelo Governo Federal. Desta forma, a falta de investimentos nos setores industriais levou ao sucateamento dos equipamentos, afetando tanto a questão operacional quanto ambiental. Ao fim da ditadura militar iniciou-se o processo de privatização das empresas. A maioria das privatizações ocorreu de 1990 até 1995. Em termos econômicos, verificouse neste cenário uma paralisação do desenvolvimento industrial, sem o "boom” ocorrido no cenário passado. Porém, mesmo diante à crise econômica no país, houve necessidade de pesados investimentos das indústrias para renovação de equipamentos e instalação de sistemas de controle de poluição em função do cenário caótico que foi desenvolvido nas décadas passadas. Em contrapartida, as ações do Governo Federal foram direcionadas ao desenvolvimento do agronegócio, que incentivou a produção e exportação de grãos.

Observa-se que os níveis de ocupação no Município de Cubatão e reflexos na Baixada Santista também se mantiveram estáveis em relação à dinâmica e o crescimento do Município. Medidas de gestão ambiental, como a remoção de bairros operários, início da remoção de comunidades assentadas em mangues, restingas e morros, levaram à necessidade de interface entre Governo do Estado de São Paulo e Município de Cubatão para a implantação de programas sociais, como a construção de núcleos habitacionais e leis de zoneamento. Estas ações tiveram além do reflexo na questão ambiental, também reflexo positivo no âmbito social.

Com a modernização das empresas e adequações ambientais, foi identificada a necessidade de contratação de profissionais mais especializados. Para atender à demanda das indústrias, a mão-de-obra especializada estava localizada nos grandes centros como o Município de São Paulo. Estes trabalhadores, na sua maioria, não se fixaram em Cubatão, permanecendo em São Paulo ou instalando-se em outros municípios da Baixada Santista, destacando-se entre eles, o Município de Santos. Esta situação levou a um aumento da circulação entre o Planalto e as demais cidades da Baixada Santista, aumentando o fluxo de veículos nas estradas, principalmente veículos leves e ônibus, porém sem ainda se tornar um problema constante.

A logística para atendimento ao Polo Industrial de Cubatão, que consistia basicamente de modais ferroviário e rodoviário (caminhões) continuou sendo compatível com o desenvolvimento da indústria, porém, um fato novo estava se apresentando ao Polo Industrial com a instalação de um terminal de cargas rodoferroviário. Este terminal de cargas levou a uma intensificação da movimentação do tráfego na região. Apareciam sinais que uma mudança na dinâmica estava ocorrendo no Polo Industrial.

Durante este período, foi marcante a implantação do plano de ações ambientais. As ações foram fortes, direcionadas, e com grandes investimentos. O fato importante é que estas foram estabelecidas considerando especificamente a região em questão, ou seja, Cubatão e o Polo Industrial. O foco permitiu assertividade nas ações e, com isso, resultados positivos. Os resultados positivos foram obtidos em longo prazo, mas o foco 
nas ações e fiscalização foi mantido ao longo dos anos. O reconhecimento deste esforço, veio em 1992, por meio da outorga, pela ONU, do título "Cidade símbolo de recuperação ambiental” à Cubatão, durante o encontro denominado ECO-92, no Rio de Janeiro.

Uma das ações para controle da poluição do ar foi a implantação da Operação Inverno para controle dos episódios críticos de poluição do ar para o parâmetro material particulado $\left(\mathrm{MP}_{10}\right)$. As ações de contingência durante os episódios críticos de poluição do ar são diferenciadas em relação às ações de controle normais, sendo mais rigorosas. Para o cenário em questão, as ações que foram adotadas, para controle dos episódios críticos, foram diretamente relacionadas à produção das indústrias do Polo, o que se verificou serem apropriadas à realidade e ao cenário existente à época, trazendo resultados efetivos quando aplicadas. O principal resultado observado foi que, desde 1995, não ocorreram mais episódios críticos de poluição do ar em Cubatão.

Com o aumento da circulação de caminhões no CINCU, avaliou-se que o aumento do tráfego poderia estar influenciando os índices de monitoramento para $\mathrm{MP}_{10}$ na estação Cubatão-Vila Parisi, uma vez que a estação medidora de qualidade do ar encontrava-se em frente à entrada do CINCU. Com isso, identificou-se a necessidade de adoção de ações complementares, pelas indústrias do Polo de Cubatão, propondo à CETESB que, durante a Operação Inverno, ações mitigadoras para evitar a ressuspensão de poeira das vias de acesso ao Polo seriam adotadas pela iniciativa privada (Plano de Ações Preventivas para controle da poluição do ar - CIESP- Cubatão), com apoio de diversas entidades como CETESB-Cubatão, Polícia Militar Rodoviária, Polícia Militar, ECOVIAS, Prefeitura de Cubatão e CMT- Cubatão. O Plano de Ações Preventivas foi um demonstrativo de que as ações necessárias para controle da poluição do ar necessitavam de reavaliação em função do novo cenário que estava se delineando. Para este cenário, observa-se que esta primeira necessidade de reavaliação ocorreu em 15 anos. O período de 1981 a 2000 foi ilustrado na figura 29. 
Figura 29: Cenário 1981 - 2000 - Implantação de ações de gestão - controle

\section{$\underline{1981-2000}$}

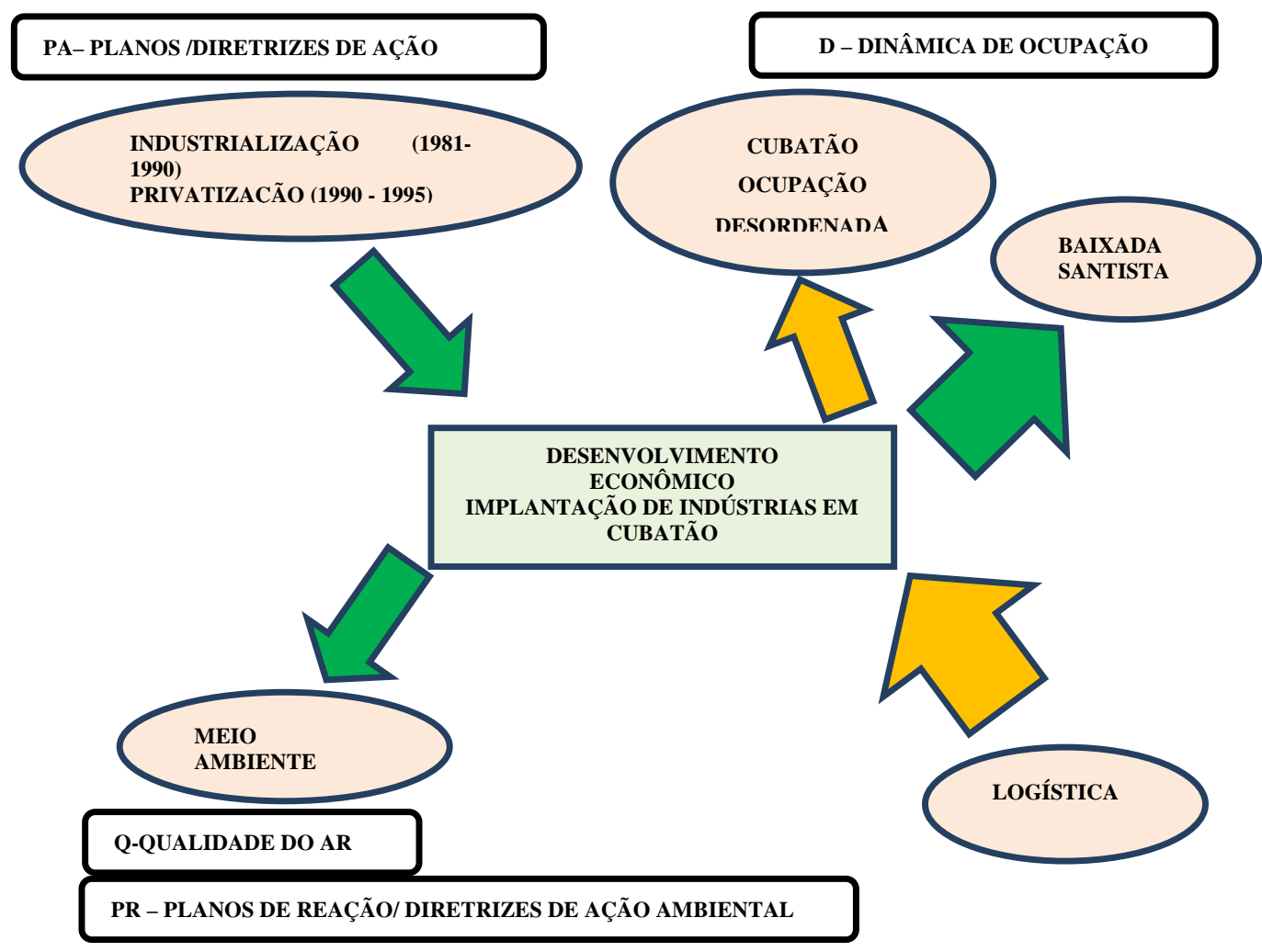

Fonte: elaboração própria

\subsubsection{Discussão do Cenário 2001 - 2013}

O marco principal para o estabelecimento deste cenário foi o início da mudança da dinâmica da região, com o crescente desenvolvimento das atividades logísticas no Polo Industrial de Cubatão.

As políticas de desenvolvimento econômico instaladas, a partir de 2000, tinham forte viés de expansão do agronegócio e, consequentemente, de exportações, com ações voltadas à expansão portuária e incentivo à produção de grãos. Isto ocasionou o impacto no Polo Industrial de Cubatão do intenso tráfego direcionado ao Porto de Santos nos períodos de safra. Outra diretriz de Governo Federal que influenciou a região foi o lançamento do programa da PETROBRAS - PRE-SAL, com a perspectiva de aumento da produção de petróleo na Bacia de Santos, atraindo investimentos diversos à região, principalmente na área da construção civil, que gerou um "boom” imobiliário na Baixada Santista, aumentando a circulação de pessoas nas estradas, nas cidades, causando congestionamentos nas estradas e nas cidades. 
Passam a ocorrer filas na entrada da cidade ocasionadas por caminhões que, ao chegarem a Santos, não conseguiam descarregar, pois os pátios no Porto já não comportavam mais caminhões. As filas começaram a causar congestionamentos na entrada de Santos, refletindo nas estradas da região. O que representava como uma atividade econômica positiva sofreu impactos com os congestionamentos e acarretou perdas para o setor de exportação de grãos e para o setor industrial da região.

Buscando equacionar o problema, foram estabelecidos pátios para que os caminhões fossem desviados enquanto esperavam para descarregar. Como não havia mais espaço em Santos, estes pátios foram estabelecidos em Cubatão, no Polo Industrial. Esta nova dinâmica na região foi observada com mais intensidade após 2004, quando se estabeleceu na região mais de 10 pátios de caminhões para apoio às operações do Porto de Santos.

Ações de controle de tráfego nas estradas, após o caos detectado nas estradas da região, em 2013, foram adotadas com a criação de pátios de espera no Planalto, no alto da Serra, de forma que, quando havia sinais de congestionamento, os caminhões ficavam estacionados até a liberação das vias na Baixada; a implantação de novas faixas na Rodovia dos Imigrantes até a duplicação da Domenico Rangoni, pela ECOVIAS, finalizadas em 2014.

A qualidade do ar neste período manteve-se sob controle, de forma que permaneceu o estado de não ocorrência de episódios críticos de poluição do ar, porém os índices de qualidade do ar para o $\mathrm{MP}_{10}$ demonstraram, neste período, que alguns marcos foram identificados. A estação medidora de Cubatão-Vila Parisi, que é a mais sensível às alterações da dinâmica, apresentou tendências de aumento dos índices de $\mathrm{MP}_{10}$, enquanto que a estação medidora Cubatão- Centro apresentou resultados positivos, dentro dos padrões de qualidade do ar estabelecidos até 2013. A estação medidora Cubatão- V. Mogi apresentou tendência de aumento dos índices de $\mathrm{MP}_{10}$, porém não de uma forma significativa se comparada à estação Cubatão-V. Parisi. O ano de 2009 foi atípico em função das fortes chuvas ocorridas durante o inverno e, por ser um ano também caracterizado por forte crise econômica mundial, que acabou afetando produção e exportação. Desta forma, estes índices foram relevados quando desta análise. Também visando o controle da poluição do ar, neste período foram promulgadas leis federais e estaduais visando o controle de fontes fixas e móveis. O período de 2001 a 2013 foi ilustrado na figura 30. 
Figura 30: Cenário 2001 - 2013 - Alteração da dinâmica - qualidade do ar

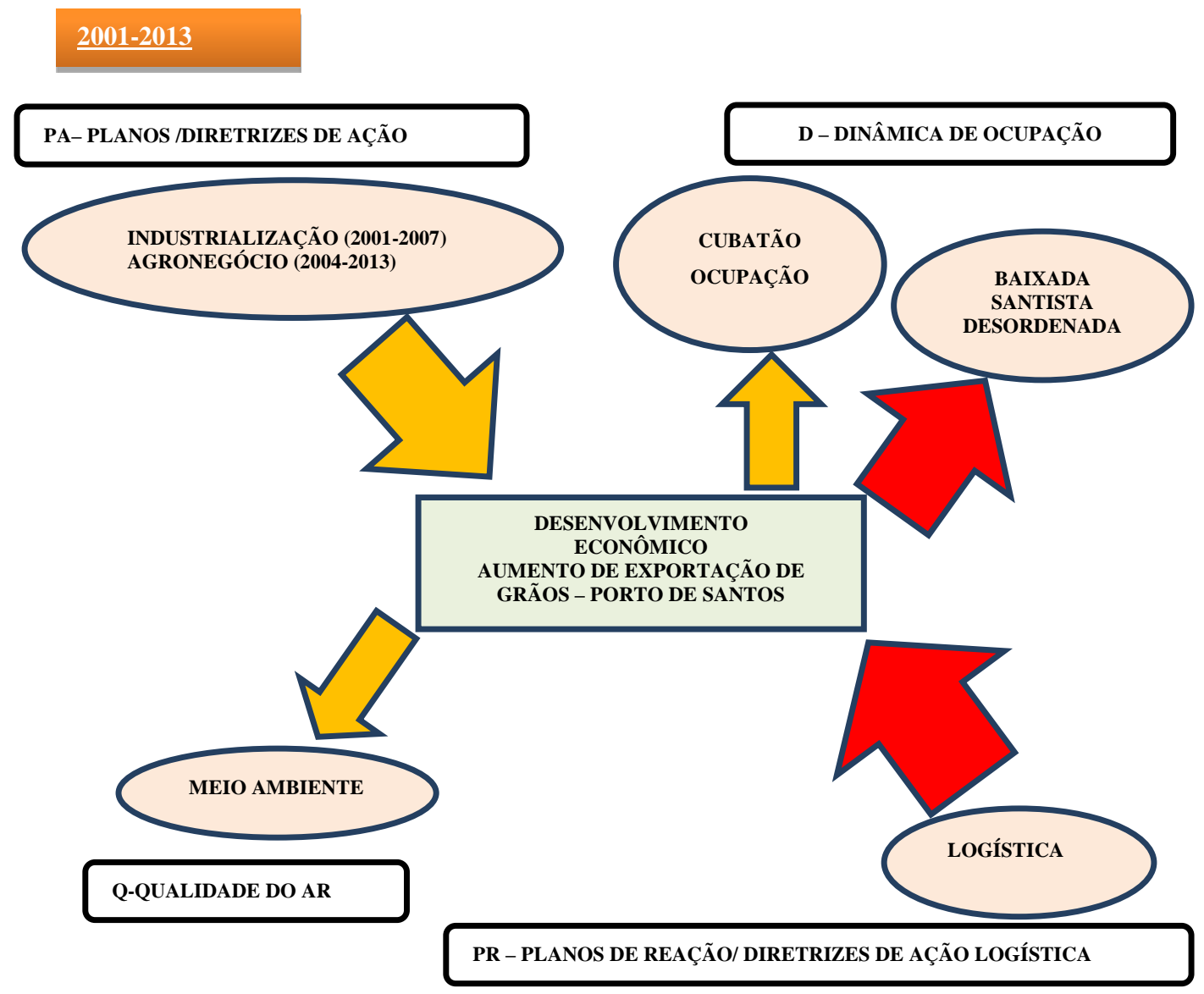

Fonte: elaboração própria

\subsubsection{Definição de elementos-chave}

As situações características de cada cenário foram definidas observando-se o conjunto de ações e reações ocorridas num período em que houve forte influência umas sobre as outras, influenciando os indicadores de qualidade do ar.

No cenário de 1950 a 1980, não foram analisadas as ações de gestão ambiental para controle da qualidade do ar, pois estas ainda não haviam sido desenvolvidas. Este cenário foi considerado importante para a análise geral, pois se observa a evolução do problema, surgindo a necessidade de adoção de ações de controle.

Para definição dos elementos-chave foram levadas em consideração as situações que caracterizam um potencial de influência nos índices monitorados para o parâmetro material particulado ( $\mathrm{MP}_{10}$ ), que, para o caso de Cubatão (Vila Parisi e Vale do Mogi), é o parâmetro crítico. Foram considerados como referência, para identificar as alterações da qualidade do ar, dados medidos a partir da década de 1980, período em que se iniciou a operação das estações medidoras em Cubatão pela CETESB. 
Desta forma, foi possível atender os objetivos específicos quais sejam a identificação e análise dos cenários, a dinâmica e a evolução da qualidade do ar do Município de Cubatão e entorno, e descrição dos elementos-chave que possam influenciar na qualidade do ar na localidade do estudo.

Foram definidos quatro elementos-chave, considerando a evolução da qualidade do ar em Cubatão, com relação ao parâmetro material particulado $\mathrm{MP}_{10}$, que é o parâmetro crítico para o Município, principalmente na região do Polo Industrial. Estes elementoschave são: "Planos/Diretrizes de Ação (Políticas)”, "Dinâmica de Ocupação”, "Qualidade do ar” e "Planos de Reação".

Com base nestes quatro elementos-chave, o cenário de 2013 foi apresentado como conceituação do problema para a próxima fase desta pesquisa que é o desenvolvimento de protótipo. Para a conceituação do problema foi apresentada a situação complexa que é o Polo Industrial de Cubatão, que para o cenário atual envolve grande circulação de caminhões para atendimento ao Porto de Santos, pátios reguladores, congestionamentos e circulação próxima às estações medidoras. Em paralelo, considerando a interação entre estes quatro elementos-chave identificados e analisados, tem-se como resultado da fase empírica a proposição de um protótipo para equacionamento da situação delineada no Município de Cubatão e entorno.

\subsection{IDENTIFICAÇÃO DE FERRAMENTAS E DESENVOLVIMENTO DE PROTÓTIPO}

A seguir seguem relatos dos resultados do desenvolvimento de protótipo, elaborados pela equipe de alunos da disciplina oferecida pela Escola Politécnica, com apoio do InovaLab@POLI. A participação da pesquisadora neste processo consistiu no acompanhamento das ideias e suporte para alinhamento do escopo, frente ao problema apresentado.

Os resultados encontrados durante a conceituação do problema demonstram a complexidade da região, que além do envolvimento de grande circulação de caminhões para atendimento ao Porto de Santos, pátios reguladores, congestionamentos que promovem o desgaste social e econômico que isto representa, há também a ser considerada a vertente ambiental, pelas características climáticas e topográficas peculiares da região.

Utilizando a metodologia do design thinking, já apresentada no capítulo 2 desta dissertação, foi concluída a fase da ideação, considerando a complexidade do problema, o desenvolvimento do persona, as necessidades dos usuários, benchmarking e entrevistas.

Como resultados da fase de ideação, prevista na metodologia, foram identificadas cinco categorias para desenvolvimento de propostas: produtores, porto, gerenciamento, modais e Município de Cubatão, que são trazidas em seguida. 
$\checkmark$ Para os produtores, a proposta foi adotar benefícios que estimulassem a organização dos escoamentos, tendo sido apresentada também, como inovação, uma proposta de armazéns emergenciais compactáveis para estocar a produção excedente; inovação em embalagens (containers) ou outros dispositivos para escoamento dos produtos (mais leves, resistentes, sustentáveis).

$\checkmark$ Para o Porto foram propostas diversas alternativas como promover a automatização, com movimentação de guindastes e caminhões por robôs (semelhante ao Porto de Rotterdam); rastreamento de navios com utilização de satélites ao invés de radares; criação de plataformas dentro do Porto que permitam a retirada de caminhões quebrados ou adiantados; expediente dos órgãos envolvidos (DOCAS, ANVISA, Receita Federal, Ministério da Agricultura, e outros) por 24 horas, com integração entre esses órgãos, com a realização de atuação em série para agilizar o processo de liberação de carga, (estilo "fordismo"), ou atuar em conjunto uma única vez, com a finalidade de que o container seja aberto apenas uma vez.

$\checkmark$ Ainda para o Porto, uma proposta seria a utilização de um scanner nos containers, para evitar ao máximo a abertura dos mesmos de forma a agilizar a liberação das cargas. Apesar de atualmente já serem utilizados Raios-X na inspeção, este fato não elimina a necessidade de abertura dos containers. A proposta poderia ganhar tempo, mesmo que não pudesse ser aplicada a todos os tipos de cargas. Também foi proposto para que fosse desenvolvido um sistema de "Alerta de pico de caminhões" para os casos em que houvesse acúmulo de caminhões nos pátios, com o alerta de pico resultaria em mudança do foco das ações dos funcionários de forma a propiciar a carga ou descarga de forma mais rápida, diminuindo o acúmulo.

$\checkmark$ Como proposta de gerenciamento, foi sugerida a sincronização de chegada dos caminhões ao Porto de Santos, uma vez que a falta de sincronismo com o horário agendado foi o fator mais crítico para o trânsito nas vias de acesso ao Porto e aos municípios de Santos e Cubatão. A situação ideal seria que os caminhões chegassem meia hora antes do horário agendado, dirigindo-se diretamente ao terminal de destino evitando acúmulo de veículos. Sendo assim, foi proposta a utilização de credenciais ou placas para identificar o horário e o terminal de destino, provendo o correto enfileiramento dos caminhões; outra proposta foi a criação de um sistema dinâmico que colete as informações dos caminhões durante o percurso e organize a descida para a Baixada Santista desde

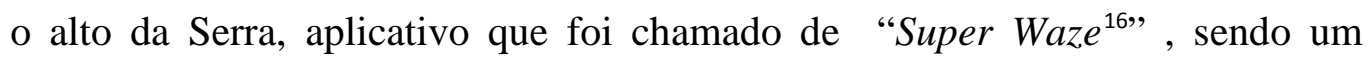

16 "Waze” é uma aplicação para smartphones ou dispositivos móveis similares baseada na navegação por satélite (ex.: GPS) e que fornece informações em tempo real e informações de usuários e detalhes sobre rotas. Fonte: <http://pt.wikipedia.org/wiki/Waze > 
sistema de informações coletadas de posição e velocidade médias por meio de aplicativos com informações GPS, informando e orientando o caminhoneiro para descansar ou realizar paradas para acertar o agendamento; criação de um Painel informativo de cabine com informações como fluxo, previsão de tráfego, horários permitidos, chuva intensa e outros . Com estas informações seriam definidas as estratégias de percurso e paradas, podendo estas informações ser passadas por aplicativo ou por painéis nos guichês do pedágio, que após a leitura da placa, as informações seriam fornecidas diretamente na cabine do caminhoneiro. (FIGUEIREDO et al, 2014, pp. 19-23).

$\checkmark$ Para as categorias modais, foram propostas soluções considerando a influência das emissões veiculares e de ressuspensão de poeiras devido à movimentação de caminhões no entorno das estações medidoras. Uma das propostas foi a criação de um simulador de períodos críticos de acúmulo de caminhões na estrada ou no entorno de Cubatão. Também foi proposta a criação de uma sala de controle, a exemplo de estudos de caso de sucesso, esta sala de controle teria um sistema de auxílio na gestão, com o diferencial que esta sala seria o local para que o "Gestor otimizador da qualidade do ar” tome as decisões. O sistema de auxílio na gestão compreenderia informações de diversos órgãos, e esse gestor identificaria as ações a serem adotadas em caso de anormalidades; também foi discutida a ideia de realizar uma inspeção obrigatória e automatizada dos caminhões nos postos de pesagem de forma similar ao sistema CONTROLAR ${ }^{17}$ para verificar a emissão de poluentes nos veículos.(FIGUEIREDO et al, 2014, pp. 23, 24).

$\checkmark$ Ainda com relação a modais, foram discutidas ideias, para levar grandes volumes de grãos até a Baixada Santista. Foi discutida a proposta do graneloduto, que consiste na implantação de um sistema onde os grãos seriam descarregados no alto da Serra e transportados por dutos até o terminal de embarque. O funcionamento pode ser feito por meio de pressurização a vácuo ou sopradores e ser construído dentro do maciço rochoso da Serra do Mar, a exemplo da usina hidrelétrica Henry Borden. A inclinação pode favorecer o não entupimento dos dutos, não sendo necessária energia;

$\checkmark$ outra ideia apresentada foi a utilização de esteiras dentadas para engate de cargas no planalto (containers) como uma ferrovia e a descida da Serra seria simplificada quanto às máquinas necessárias, uma vez que seria gerenciado um

17 CONTROLAR - Programa de Inspeção e Manutenção de Veículos em Uso I/M- SP definido pelas Leis Municipais $n^{\circ} 11.733$ de 27 de março de 1995, $n^{\circ} 12.157$ de 09 de agosto de 1996 e $n^{\circ} 14.717$ de 17 de abril de 2008 e pelas resoluções do Conselho Nacional de Meio Ambiente - CONAMA e previsto no Artigo 104 do Código de Trânsito Brasileiro - CTB. 
fluxo de container, de forma rápida e não poluente, diminuindo o número de caminhões para transportar alguns produtos;

$\checkmark$ Foi discutido também um sistema de intercalação de modais, estendendo a ideia de esteiras dentadas, como forma de escoamento da produção, deixando de escoar a produção totalmente por rodovias, intercalando com outros modais como correias que descem a serra, hidrovias utilizando os rios de Cubatão ou transporte do interior do Brasil por avião para Santos;

$\checkmark$ Propostas de ideias como os trens com frenagem regenerativa, que seriam uma alternativa para o sistema ferroviário atual foram apresentadas. Na descida da Serra do Mar, as frenagens das máquinas são um problema devido ao alto consumo de energia. Como alternativa, a proposta utilizaria o sistema de frenagem regenerativa nos trens, que seria um sistema que durante a descida da Serra, um gerador elétrico freia os vagões, transformando a energia cinética em elétrica. A locomotiva que atualmente necessita o sistema de cremalheira para conter a descida atuaria como sincronizador para devolução à rede. Tal energia poderia ser usada para subida de cargas, ou para outras utilizações;

$\checkmark$ Identificou-se, com base num projeto apresentado pelos chineses para transporte de pessoas, uma proposta utilizando o conceito de trilhos sobre rodas. $O$ projeto prevê um meio de transporte de pessoas em que o fluxo de veículos passa por baixo do "trem" sem atrapalhar o fluxo. A proposta seria utilizar este projeto para que, ao invés de transporte de pessoas, pudessem ser transportadas cargas. As cargas poderiam ser carregadas por içamento ou sucção (FIGUEIREDO et al, 2014, pp. 24,25).

$\checkmark$ A proposta para a categoria que seria de interesse para o Município de Cubatão envolve a distinção das fontes de poluição, realizando medições e caracterizações para identificar suas origens. Esta proposta é uma medida viável, mencionada em entrevista com a agência ambiental de Cubatão (FIGUEIREDO et al, 2014, p.16), bem como recomendação do estudo de caracterização de material particulado realizado por VALARINI (2011). Outras alternativas foram discutidas, como a implantação de um anel viário ao redor da cidade para evitar que os caminhões se acumulem dentro da cidade e, a melhora dos filtros de escapamento dos caminhões, para aumentar a eficiência na redução das emissões de poluentes dos escapamentos (FIGUEIREDO et al, 2014, p.25).

A partir das opções de ideação, foi caracterizado um primeiro protótipo com base em um sistema de gerenciamento que pudesse interligar informações de diferentes instituições, relacionadas diretamente com a problemática e, por meio da coordenação 
de um supervisor, seriam geradas ações de logística. Para isso, seria utilizado o aplicativo “Super Waze” (nome fantasia), que começa a funcionar já desde o momento que o produtor fizer o agendamento da carga em Santos. Com o horário programado e a distância da origem, o sistema calcula o tempo de viagem, já incluindo os possíveis congestionamentos, horários de rodízio e velocidade média. Com estas informações, o programa define o horário que o caminhoneiro deve sair e, durante o percurso, com informações passadas a um smartphone ou tablet, o motorista será avisado quanto à velocidade ideal para trafegar e, os pontos de parada para descanso e alimentação, com o objetivo de ordenar os caminhões de acordo com o horário de entrega agendado, fazendo com que os veículos já entrem no porto de Santos na ordem correta, evitando assim, filas de caminhões (FIGUEIREDO et al, 2014).

De acordo com Hijjar ${ }^{18}$, 2004, citado por Figueiredo et al (2014, p.30):

“o modal rodoviário vem a ser mais adequado para o transporte de cargas em distâncias consideradas curtas, ou seja, para trajetos de até 300 quilômetros. Este atuaria nas chamadas pontas; do local de origem, nesse caso fazendas produtoras, até os armazéns ou terminais ferroviários ou hidroviários, os quais, então, ficariam responsáveis pelo transporte a longas distâncias, dadas a maior capacidade de carga e a possibilidade de reduzir custos e perdas" (FIGUEIREDO et al , 2014, p. 30).

Contudo, para Figueiredo et al (2014, p.30), várias razões fazem com que o modal rodoviário não seja adequado ao escoamento da produção de soja do Centro-Oeste para os portos de exportação nas regiões Sul e Sudeste, como por exemplo, a longa distância a ser percorrida combinada com as variáveis inerentes desse modal, a pequena capacidade de carga; o custo médio superior (tonelada/km) e, de maior relevância, o maior consumo de energia (combustível fóssil). Assim sendo, o país tem perdas na competitividade da produção de soja, pelo fato do escoamento dessa produção se concentrar no modal rodoviário, o qual é inadequado para o transporte de cargas volumosas e de baixo valor agregado. É possível contabilizar a quantidade de energia gasta no modal rodoviário que, além de mais caro, é mais poluente (Tabela 1).

${ }^{18}$ HIJJAR, M. F. Logística, soja e comércio internacional. Centro de Estudo em, 2004. 
Tabela 1: Eficiência energética entre as modalidades de transporte de carga

\begin{tabular}{|l|l|l|}
\hline Modalidade & Ton-Km/1* & MJ/ton-km \\
\hline Rodovia & 25 & 3,53 \\
\hline Ferrovia & 88 & 1,02 \\
\hline Hidrovia & 98 & 0,93 \\
\hline Aerovia & 2 & 40,70 \\
\hline Dutovia & 120 & 0,74 \\
\hline
\end{tabular}

Fonte: CORREA e $\operatorname{RAMOS}^{19}(2010$, p.451) citados por FIGUEIREDO et al (2014)

A partir destas informações e considerando o baixo consumo de energia e a premissa de minimizar a emissão de poluentes no local de estudo, o transporte de grãos, principalmente a soja, por meio de dutos se mostrou uma ótima saída para Cubatão, já que reduziria o número de caminhões das vias.

Sendo assim, foi estabelecido um protótipo do tipo dark horse. O termo dark horse constitui uma das etapas do método de design thinking, sendo uma metáfora dos eventos de corridas de cavalos, em que a maioria das pessoas não apostaria nada em um cavalo "azarão" que, ao final, caso ganhe a corrida, representa grande ganho (inovação).

Antes do desenvolvimento do protótipo dark horse foi feito um reenquadramento dos antigos pressupostos. Para tornar a ideia possível, o duto foi planejado para fazer somente o percurso de descida da serra. A carga seria recebida no alto da serra por um terminal, desceria pela ação da gravidade e seria distribuída na Baixada por esteiras fechadas até o terminal destino.

O protótipo final escolhido seguiu a solução elaborada no dark horse, testando a viabilidade do projeto e adequando-o aos requisitos esperados para este empreendimento. Calabrezi $^{20}$ (2005) citado por Figueiredo et al (2014) destaca que cada modal possui vantagens e desvantagens quando utilizado individualmente. Entretanto, os aspectos negativos podem ser minimizados com a combinação entre dois ou mais modais de transportes, muito embora, para que esta integração seja realizada, seja imprescindível a estrutura de apoio do terminal intermodal.

De acordo com Sogabe ${ }^{21}$ (2010), citado por Figueiredo et al (2014), o transbordo da carga de um modal para outro demanda uma estrutura física adequada - denominado de

${ }^{19}$ CORREA, V.H.C.; RAMOS, P. A Precariedade do Transporte Rodoviário Brasileiro para o Escoamento da Produção de Soja do Centro-Oeste: situação e perspectivas. RESR, Piracicaba, SP, vol. 48, $n^{o}$ 02, p. 447-472, abr/jun 2010.

${ }^{20}$ CALABREZI, S. R. S. A multimodalidade para o transporte de cargas: identificação de problemas em terminais visando à integração dos modais aéreo e rodoviário. 2005. $139 \mathrm{f}$. Dissertação (Mestrado em Engenharia Civil) - Faculdade de Engenharia Civil, Arquitetura e Urbanismo, Universidade Estadual de Campinas, Campinas, 2005.

${ }^{21}$ SOGABE, V. P. Caracterização do desempenho operacional em terminais intermodais de escoamento de grãos: um estudo multicaso no corredor Centro-Oeste. 2010. $122 f-$ 
terminal intermodal - para que a transferência seja feita da maneira mais eficiente possível.

Por essa razão, foi decidido fazer no protótipo final, um melhoramento do dark horse, focando especialmente no terminal intermodal, entre o modal rodoviário e o dutoviário.

Os requisitos levantados por Figueiredo et al (2014, p.34), e que guiaram o protótipo final foram:

$\checkmark$ Minimizar a necessidade do uso do transporte rodoviário nos transportes de grãos de soja e milho no trajeto entre o Alto da Serra e a baixada Santista;

$\checkmark$ Garantir tempo mínimo ocioso em relação à capacidade total instalada do sistema;

$\checkmark$ Minimizar o impacto na área de preservação da Serra do Mar, para isso destacam-se três aspectos:

- Minimizar a área ocupada pelos terminais do Alto e Pé da Serra, tendo para isso operação maximizada e minimização do espaço ocupado por armazenagem;

- Tecnologia de instalação com menor impacto;

- Acesso aos terminais não representarão abertura de nova rodovia;

$\checkmark$ Não transferir o problema de filas e trânsito que ocorrem na baixada para o alto da Serra;

$\checkmark$ Garantir segurança aos transportadores e funcionamento 24h por dia;

$\checkmark$ Garantir manutenção das instalações de forma fácil;

$\checkmark$ Garantir possibilidade de planos de contingência para eventuais paradas no sistema, sem gerar riscos aos colaboradores e à carga.

Desta forma foi proposta a criação da ESCOA - Transportes Dutoviários, empresa fictícia com o objetivo de escoar a produção de granéis sólidos, inicialmente operando para a soja e o milho, de maneira eficiente. Esta empresa deve operar observando: rapidez no escoamento; diminuição das perdas de carga no transporte; redução dos impactos sociais, econômicos e ambientais, que são gerados pelo modal rodoviário; operação 24/7 (24h, todos os dias); entrega da produção direto nos terminais do porto: ausentando a necessidade de outro modal entre o terminal intermodal da Escoa, no topo da serra, e os terminais do porto, na baixada santista; ser responsável pelo escoamento de $90 \%$ da produção bruta de soja e milho que passam pelo Porto de Santos.

Dissertação (Mestrado em Administração) - Departamento de Economia e Administração, Universidade Federal de Mato Grosso do Sul, Campo Grande, 2010. 
Este modelo, segundo Figueiredo et al (2014), poderia ser referência no transporte dutoviário nacional, destacando-se como pioneiro para o escoamento de grãos utilizando a força da gravidade; ter visibilidade mundial pela eficiência e qualidade do serviço prestado, observando normas internacionais de meio ambiente e sustentabilidade e operar por meio de parceria público-privada.

De acordo Figueiredo et al (2014) a arquitetura do sistema para entregar os grãos do alto da Serra até os terminais seria composta por 4 subsistemas:

1. Terminal de descarga no Alto da Serra - no qual os grãos seriam pesados e transferidos a um armazém, com a função de regular o fluxo escoado pelo Duto;

2. Duto - retilíneo, que faria o transporte por gravidade do Alto da Serra ao Pé da Serra, imediatamente no término do trecho de alta declividade;

3. Terminal do Pé da Serra - que receberia os grãos escoados pelo duto, regulando sua vazão de saída, armazenando e regulando a vazão de saída para as esteiras;

4. Esteiras transportadoras - que seriam responsáveis por levar a carga do pé da serra pela Baixada até os terminais de carga no Porto. Operariam na região de baixa declividade com capacidade controlada pela velocidade de transporte.

O sistema foi dimensionado tendo como base a exportação mensal do Porto de Santos para o ano de 2013, considerando crescimento da produção em $15 \%$.

"A vazão de pico para o sistema que transporta somente uma safra por vez é de 688.000 ton por semana, na terceira semana de Maio, o que representa veiculação de 98.000 ton por dia, ou 2.730 caminhões por dia. Entretanto o período de pico para o sistema rodoviário encontra-se na intersecção entre o começo da safra de milho e decremento da de soja, na última semana de agosto, quando há uma movimentação de 3.300 caminhões por dia (FIGUEIREDO et al, 2014, p. 36)”.

Após a construção de cenários diversos, a configuração final que foi adotada por Figueiredo et al (2014, p. 38) foi de um duto de 1,5m de diâmetro, com capacidade de veiculação e 4.000 ton por hora, significando veiculação semanal de 672.000 t, suficiente para transportar o pico individual da safra de soja. A mudança entre o transporte dos grãos seria feita entre os pontos de intersecção de exportação, o que significaria que de Março a Agosto o sistema transportaria soja em grão, e de Setembro a Fevereiro, deveria transportar milho (Figura 33). 
Figura 31: Simulação com transporte de um produto por vez com vazão de 4.000 ton/h. "ExpSoja" e "ExpMilho" representam a exportação esperada, com o transporte pelo duto nas séries "Soja" e "Milho"

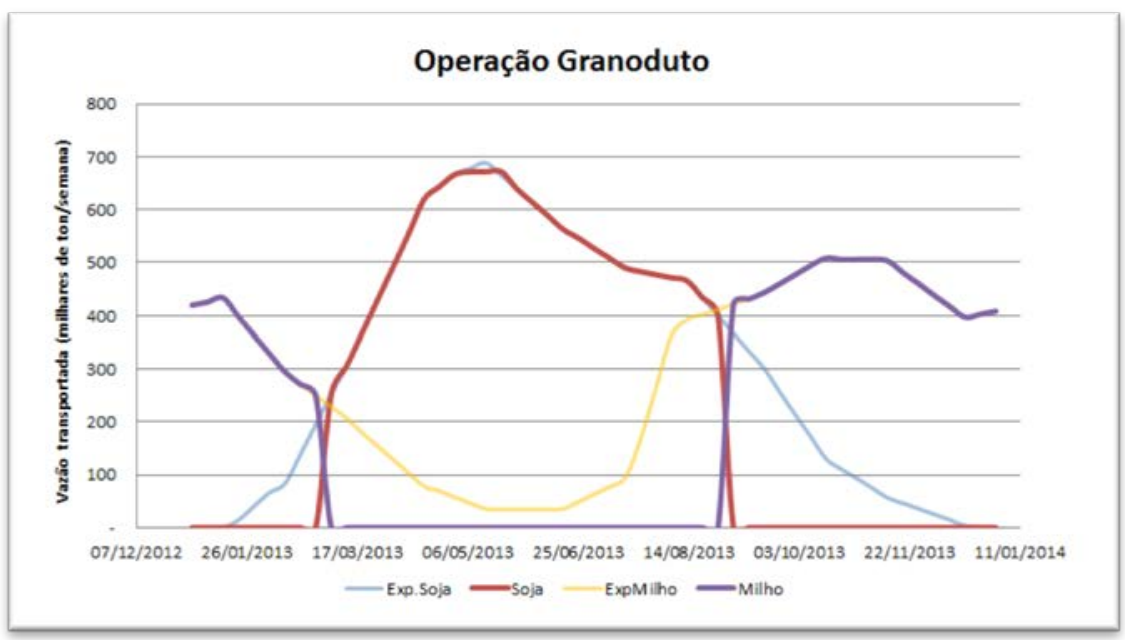

Fonte: FIGUEIREDO et al (2014), p. 38

Esta configuração permitiria transportar pelo menos $79 \%$ da carga de soja e milho e reduziria pela metade o número de caminhões que descem a serra no período crítico da última semana de Agosto para a primeira de setembro, quando soja e milho se igualam em volume (Figura 34).

Figura 32: Simulação do tráfego semanal de caminhões de soja e milho sem a implantação do duto (linha que representa a série s/duto) e depois de sua implantação, discriminando a carga transportada (colunas)

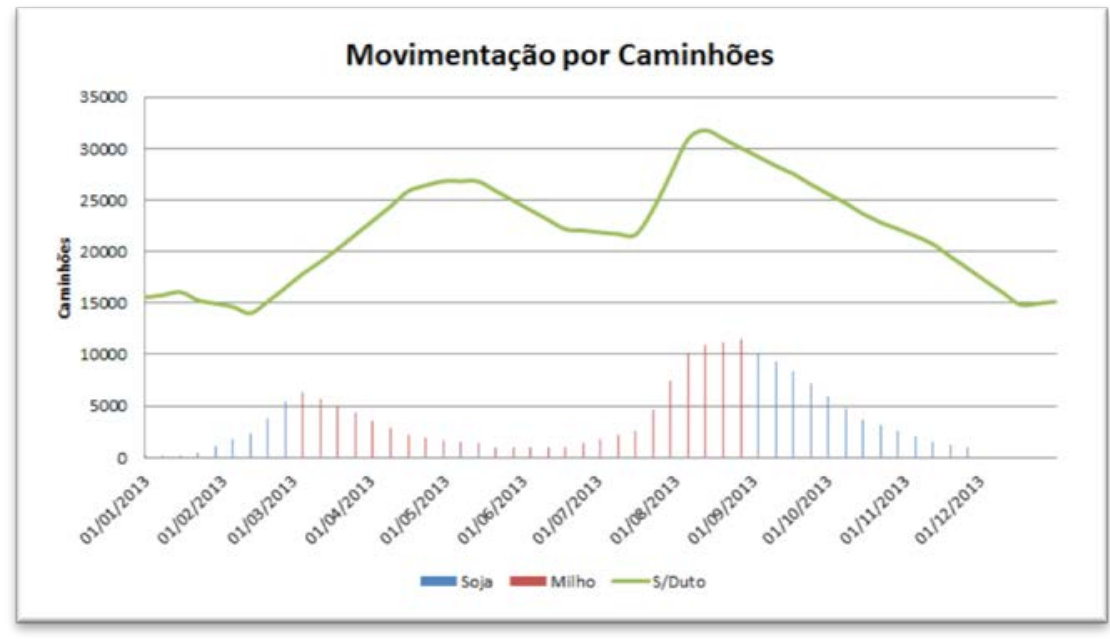

Fonte: FIGUEIREDO et al (2014), p. 38 
Observa-se que o duto operaria em capacidade máxima somente uma vez por ano. Entretanto isto significa que o sistema ainda suportaria um aumento da exportação, contando que esta seja planejada para ser distribuída nos intervalos de subutilização (FIGUEIREDO et al ,2014, p. 38).

Os benefícios econômicos gerados pelo transporte em duto poderiam ser estímulos para tal planejamento de produção ou criação de armazenamento estático próximo ao produtor, além de ser interessante migrar mercadorias do pico da união de safras para aproveitar o transporte atrativo através do duto (FIGUEIREDO et al ,2014, p. 38-39).

Outras possibilidades envolveriam arranjos operacionais de recebimento e escoamento de um produto com inversão para o outro em curto espaço de tempo que possibilitaria operação em capacidade mais próxima da máxima, absorvendo maior volume e aumentando a eficiência do sistema. Por exemplo, durante certo período, o agendamento de descarga de soja seria feito entre as 00:00 e 12:00h. Após este horário seria recebido milho e armazenado no alto da serra tão logo se possa esvaziar o terminal Pé da Serra. Sendo assim, o sistema trabalharia com capacidade máxima e não transferiria metade do volume para o rodoviário (FIGUEIREDO et al ,2014, p. 39).

A possibilidade de construção de dois dutos, um para cada safra foi descartada, tendo em vista o "Shadow Price", ou "Preço Sombra" desta decisão. Isto é, com o investimento para a construção de um duto obteríamos 79\% de redução das viagens. Entretanto dobrando o investimento transportar-se-ia somente $21 \%$ da carga, o que seria inviável, tendo em vista também que ficaria boa parte do tempo ocioso (FIGUEIREDO et al ,2014, p. 39).

O local escolhido para instalação foi escolhido por aliar acesso prévio existente tanto no alto da serra quanto na Baixada, boa declividade relativamente constante, e proximidade com outras estruturas, um oleoduto, linha de transmissão de energia e tubulações da hidroelétrica de Henry Borden. Esta área já sofreu com alterações em sua vegetação e possuem estrada de acesso e manutenção. O acesso seria feito pelo último trevo na Via Anchieta antes da descida da Serra, que faz ligação com o Sistema Imigrantes. Seria necessária a criação de um novo acesso e a partir daí seguiria pela Estrada do Mirante, esta seria utilizada para a manutenção das estruturas citadas e necessitaria de ampliação e adequação ao volume de carga esperado, entretanto seria uma vantagem, pois dispensaria a necessidade de supressão vegetal para abertura de novo caminho (Figura 35). Na Baixada Santista, o terminal do Pé da Serra também seria próximo da Via Anchieta, o que facilitaria as obras e permitiria a saída do sistema de esteiras na marginal desta via.

Obviamente destaca-se a necessidade de um Estudo Prévio de Impacto Ambiental e as Licenças correspondentes. 
Figura 33: Vista 3D dos terminais e saída das esteiras

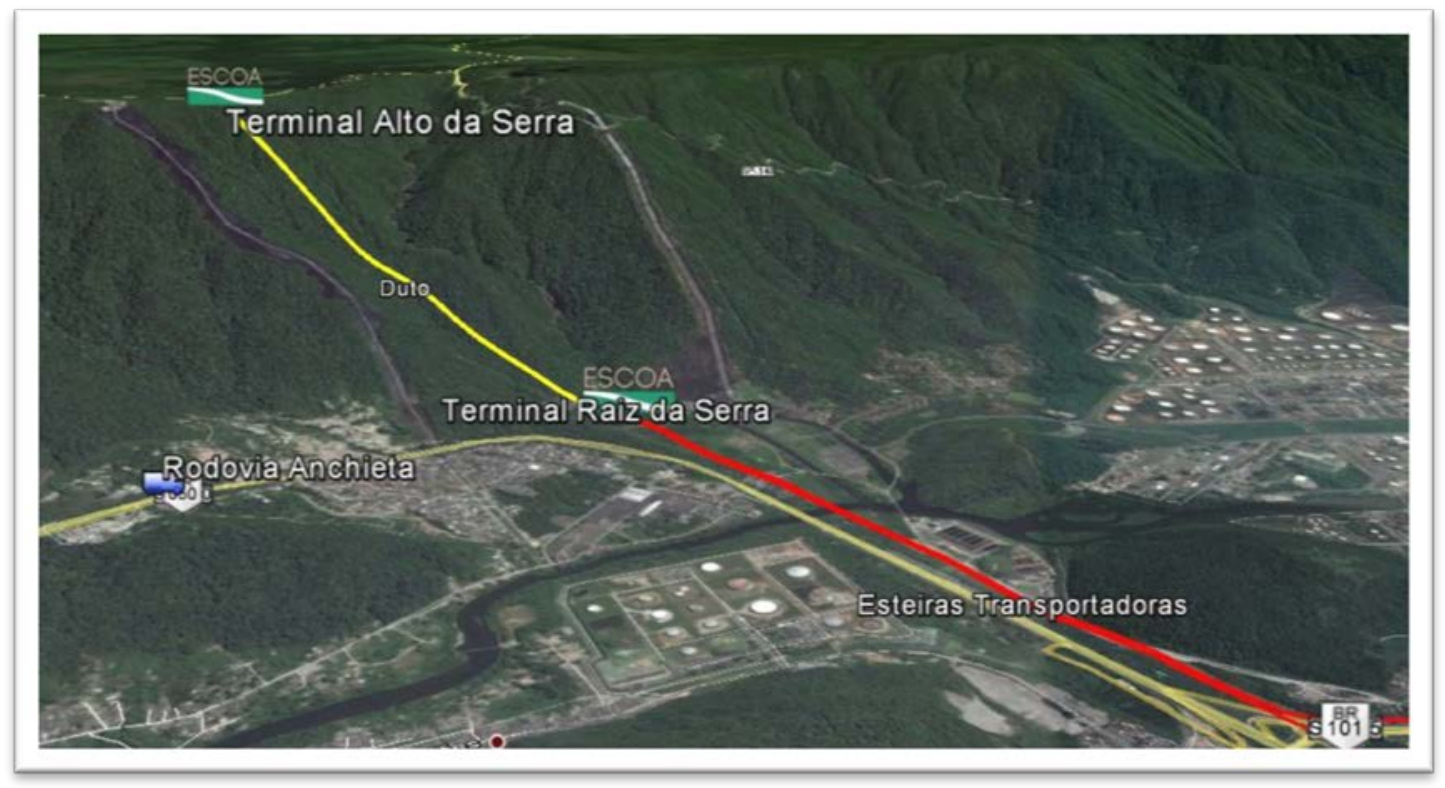

Fonte: FIGUEIREDO et al, 2014, p. 41

Da saída do terminal do Pé da Serra, as esteiras transportadoras levariam os grãos para os terminais do porto de Santos. O porto possui terminais nas duas margens do estuário de Santos, na margem Direita, Município de Santos e na margem esquerda, no município do Guarujá. Devido a isso, as esteiras também poderiam chegar aos dois lados (Figura 36). Portanto a Primeira esteira, indo para Santos seguindo a Rodovia Anchieta e depois as Ruas Antônio Prado, Av. Cidade de Santos e Av. dos Portuários até a Ponta da Praia, o chamado "Corredor de Exportação", completando a extensão de 24km. Para a margem Esquerda a esteira deveria seguir a Rodovia Cônego Domenico Rangoni, passando por Cubatão e chegando ao Guarujá, sendo desviada para a rua Cristóvão Gilardi Lopes, paralela à região portuária.

Tudo isto representaria uma extensão de $35 \mathrm{~km}$. Possíveis alternativas de traçado foram levantadas para reduzir esta distância. Entretanto a área de estudo é muito complexa, passando por áreas de preservação ambiental, por ter o manguezal e a restinga no interior do estuário, e pelo fato de que as formas do estuário não são fixas, solo mole e de difícil acesso seja na construção ou operação de esteiras que cortassem caminho. Portanto até que surjam novas propostas de traçado melhores, como por exemplo, se fosse previsto no túnel subterrâneo que ligará Santos ao Guarujá, espaço para travessia das esteiras teríamos um traçado muito mais otimizado (FIGUEIREDO et al, 2014, p. 41). 
Figura 34: Traçado das esteiras, chegando aos dois lados do estuário de Santos

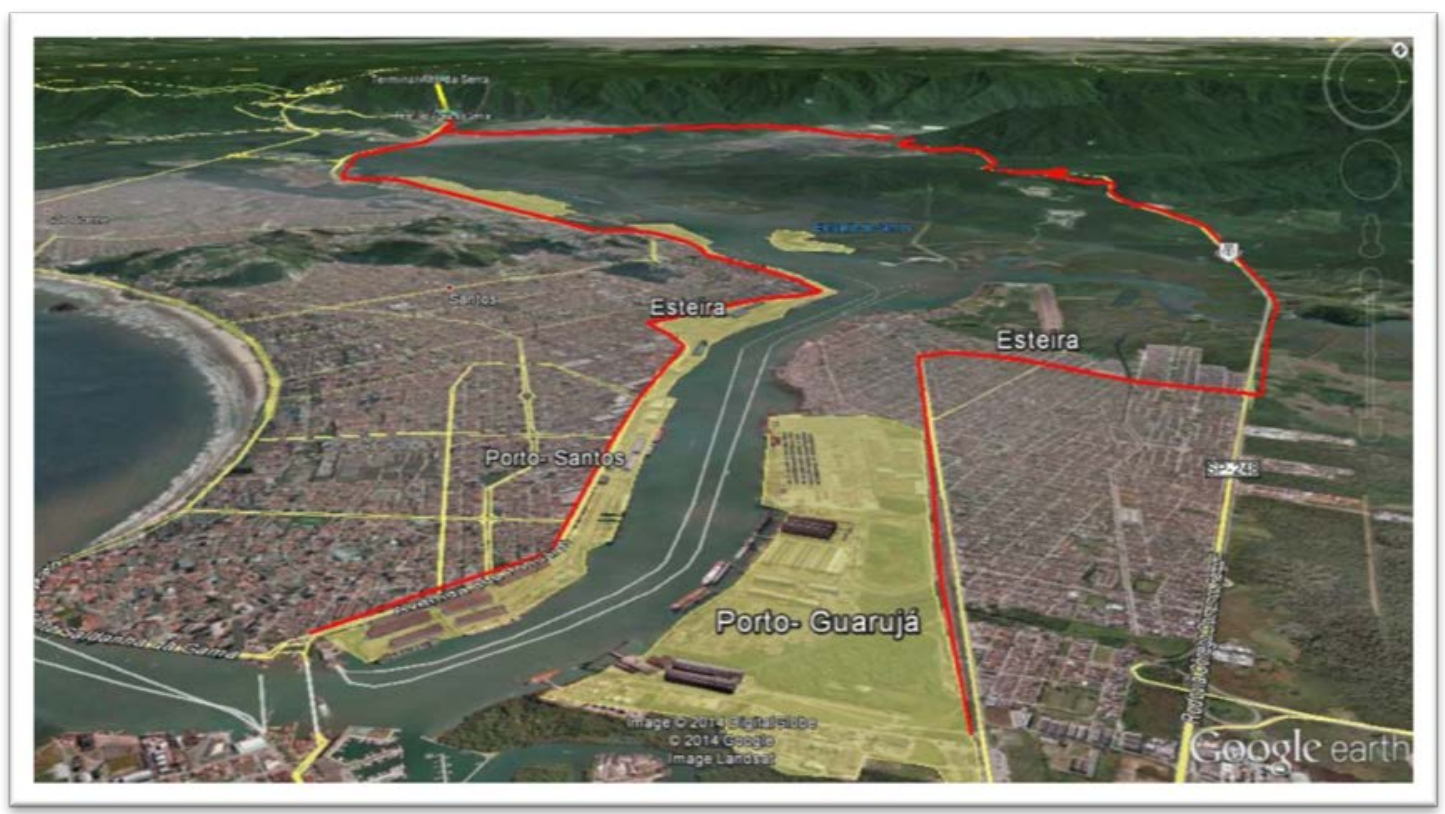

Fonte: FIGUEIREDO et al, 2014, p. 41

Os subsistemas deste Graneloduto envolveriam um terminal do Alto da Serra; Dutos; um Terminal Pé da Serra e Esteiras ${ }^{22}$.

Para não transferir os problemas de trânsito da Baixada Santista para o alto da serra, foi projetado um terminal do Alto da Serra (Figura 37) para atender de forma eficiente a demanda máxima recebida pelo sistema dutoviário, que é de escoamento de 4.000 t por hora no pico da safra de soja. Para isso planeja-se uma distribuição inteligente de todas as etapas de acesso, recepção, identificação, conferência, pesagem e descarregamento da carga, além de assegurar segurança ao transportador e carga, bem como o manuseio adequado ao gênero transportado (FIGUEIREDO et al, 2014, p. 42).

O duto teria diâmetro de $1,5 \mathrm{~m}$ com capacidade de veiculação de $4.000 \mathrm{t} / \mathrm{h}$. Sua extensão seria de 1.780 metros e inclinação de 35\%. Para manter a inclinação constante, seriam vários os trechos superados por uso de estruturas suspensas de até 5 metros de altura, estratégia recomendada para obter menor interferência no deslocamento de espécies nativas (FIGUEIREDO et al, 2014, p. 48).

\footnotetext{
${ }^{22}$ As especificações técnicas e figuras ilustrativas podem ser obtidas com maior detalhamento em FIGUEIREDO et al 2014.
} 
Figura 35: Terminal Alto da Serra

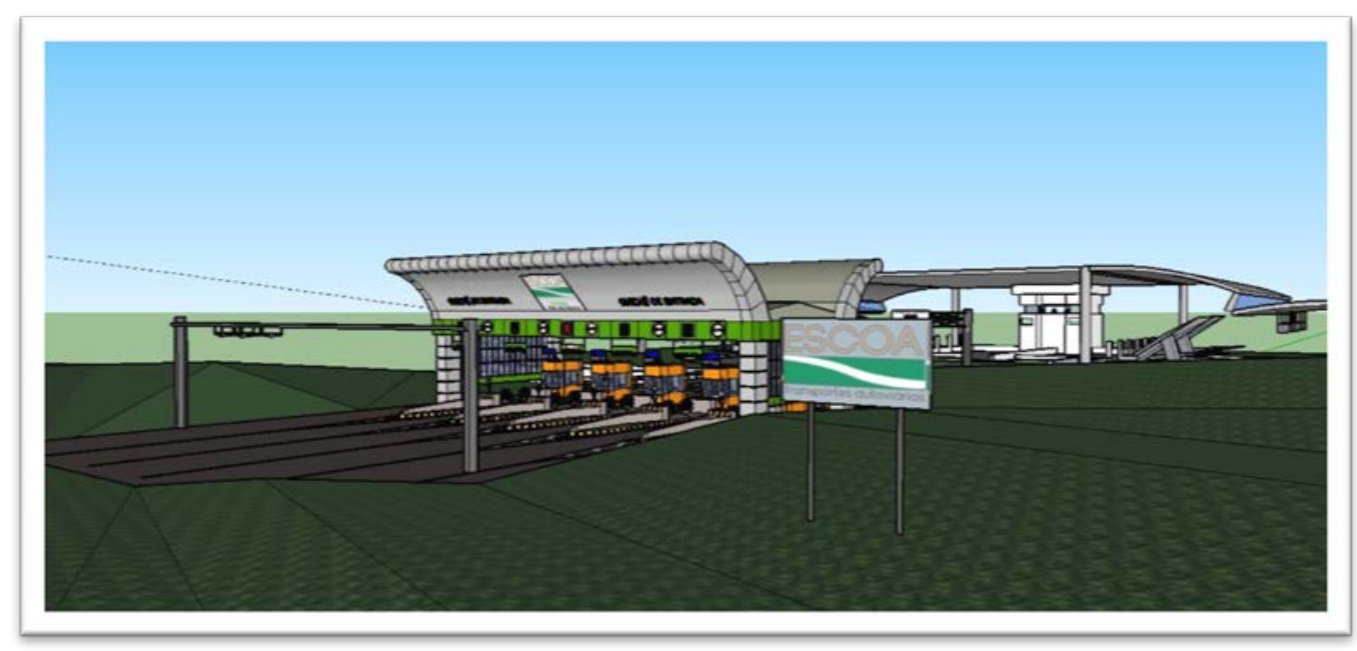

Fonte : FIGUEIREDO et al, 2014, p. 43

O terminal do Pé da Serra seria constituído por Regulador de vazão da Saída do Duto; Armazém e Regulador de vazão de saída do armazém para a esteira (FIGUEIREDO et al, 2014, p. 48).

As esteiras utilizadas teriam capacidade estipulada a partir de estudos posteriores, visto que para isto devem ser analisadas as demandas dos terminais portuários em cada margem. São necessárias informações de capacidade de armazenamento estático e fluxo de carregamento de navios de cada terminal para poder realizar os dimensionamentos.

O sistema de esteiras utilizado para transporte dos grãos poderia ser o Pipe Conveyor Belt, desenvolvido pela Bridgestone ${ }^{23}$ (Figura 38). É um produto já testado em várias partes do mundo como China e Alemanha em distâncias de $40 \mathrm{~km}$, transportando de grãos até minério. Isto traz credibilidade e maior garantia ao projeto, sendo menos uma fonte de possíveis erros ou desafios para a implantação. Esta esteira também tem a vantagem de se fechar após o carregamento e descarregamento, ficando de forma tubular (FIGUEIREDO et al, 2014, p. 49).

\footnotetext{
${ }^{23}$ BRIDGESTONE. Products. Pipe Conveyor belt. Disponível em $<$ http://www.bridqestone.com/products/diversified/conveyorbelt/products/pipe conveyor belt. $\underline{h t m l>}$
} 
Figura 36: Sistema Pipe Conveyor Belt da Bridgestone

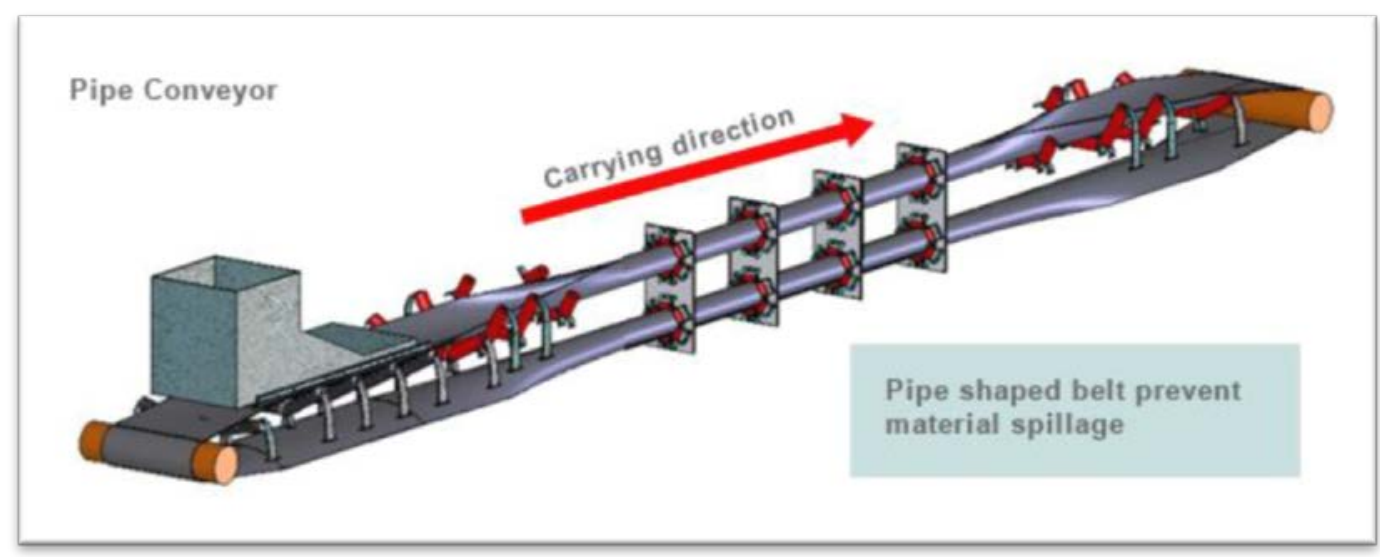

Fonte: BRIDGSTONE citado por FIGUEIREDO et al, 2014, p. 49.

\section{4 - Considerações sobre o capitulo}

As alterações ocorridas em 63 anos, tanto em relação à dinâmica quanto aos índices de qualidade do ar, foram verificadas no eixo do Polo Industrial de Cubatão e seu entorno. Isso pôde ser observado pela evolução dos índices de qualidade do ar monitorados, comparando-se as três estações medidoras, ao longo de períodos específicos.

Os três cenários foram marcados por 04 (quatro) elementos-chave que traduziram as ações e reações ocorridas em Cubatão e seu entorno, ao longo do tempo: Planos de Ação; Dinâmica; Planos de Ação Ambiental e Qualidade do Ar e demonstraram possuir inter-relações importantes na região do Polo Industrial de Cubatão, afetando-se mutuamente.

Essas relações são observadas principalmente na região da antiga Vila Parisi, onde os índices de qualidade do ar para o parâmetro $\mathrm{MP}_{10}$ mostram valores mais significativos. É também nesta região que a dinâmica sofre maiores alterações.

A vocação, notadamente industrial, observada nos dois primeiros cenários, levou a consequências diversas. As consequências negativas ocorreram ao longo dos primeiros 30 anos, observadas com maior intensidade na região da antiga Vila Parisi e tiveram suas causas bem definidas, ou seja, os efeitos da poluição do ar eram claramente devido à atividade industrial.

Como consequências positivas, tem-se que a implantação de um plano estruturado e bem conduzido levou à recuperação ambiental do Município de Cubatão, alcançando-se um marco de quase 20 anos sem a ocorrência de episódios críticos de poluição do ar. Para a implantação desse plano foram necessárias atuações importantes de todos os segmentos: Governo Estadual, Órgãos legisladores, CETESB e Prefeitura de Cubatão, bem como entidades privadas e a população.

A alteração da dinâmica da região levou à desestabilização de um cenário equacionado. Ressalta-se, no entanto, que não se pretende afirmar que a situação esteja resolvida, uma 
vez que a qualidade do ar em Cubatão e entorno ainda não se encontra adequada aos padrões de qualidade do ar estabelecidos.

As interferências no "cenário estável” alcançado começam a ser sinalizadas a partir de 1995, com o aumento da circulação de caminhões na região, em função do estabelecimento de pátios de manobras (terminal rodoferroviário). Recentemente, observou-se nova alteração da dinâmica em função do aumento do número de pátios de caminhões estabelecidos no Polo industrial de Cubatão, para atendimento ao Porto de Santos. Percebeu-se então que com essa nova alteração, as ações existentes já começam a sinalizar que logo poderão não ser mais suficientes para o controle da qualidade do ar e o impacto em toda a região do entorno pode ser notado.

As ações propostas adotadas no passado e, que perduram até então, foram estabelecidas de forma planejada e estruturada, direcionando esforços à realidade local, como por exemplo: medidas de redução de emissões atmosféricas pelas fontes fixas (indústrias), aumento da malha de monitoramento da qualidade do ar e identificação dos principais parâmetros de interesse voltados à proteção à saúde da população, quais sejam, a adoção de ações emergenciais em casos de ultrapassagens dos padrões considerados críticos, para $\mathrm{MP}_{10}$. Estas ações emergenciais, como a redução da produção ou paralisação de processos industriais de alto potencial de emissão de poluentes e ações de limpeza e umectação das vias de acesso ao Polo Industrial, obtiveram, ao longo do tempo, resultados positivos.

Para acompanhar essas ações, a CETESB ampliou a rede de estações medidoras da qualidade do ar em Cubatão, sendo composta por três estações medidoras, quais sejam “Cubatão-Centro”, "Cubatão-V. Parisi” e "Cubatão-V. do Mogi”.

A tomada de decisão, quanto às ações de controle de poluição do ar, inclusive em caso de ocorrência de episódios críticos de poluição por $\mathrm{MP}_{10}$, é feita com base nas informações obtidas por estas estações, quais sejam, os índices de monitoramento da qualidade do ar.

Verificou-se que, do período inicial considerado (1950 a 1980), passaram-se trinta anos para que novo marco no cenário fosse identificado. A resposta à condição crítica instalada em Cubatão (1981 a 2000) constituiu um marco devido à força das medidas e eficácia das ações adotadas para que um novo cenário positivo fosse percebido. De 2001 até 2013, após treze anos, foram identificadas as necessidades de complementaç nas ações de controle. Em 2013, a publicação da nova legislação com padrões de qualidade do ar mais restritivos remete a uma nova preocupação, com potencial de estar-se vislumbrando um novo cenário. A cada cenário desenhado, reduz-se o período em que se identifica a necessidade de reavaliação das ações de controle para a qualidade do ar em Cubatão.

Buscou-se compatibilizar os resultados obtidos da análise geral dos cenários, com as ferramentas disponíveis e/ou desenvolvidas (no caso desta pesquisa, utilizou-se a metodologia do design thinking) de forma que os elementos identificados como "pistões” deste mecanismo, ou seja, os elementos-chave possam ser utilizados para visualizar as alterações da dinâmica da região e as ações de controle necessárias para se 
evitar episódios críticos da poluição do ar, de uma forma mais dinâmica, permitindo uma aplicação/utilização mais frequente.

Com o desenvolvimento da metodologia, foram discutidas várias alternativas para a região, sendo que a proposição da instalação do graneloduto pode ser considerada satisfatória, uma vez que tiraria grande parte do tráfego de caminhões das estradas, liberando congestionamentos e eliminando parte de emissões veiculares e ressuspensão de poeira das estradas. Essa ação, cuja implantação só poderia ser realizada em longo prazo, poderia ser avaliada antecipadamente, como ação de planejamento para a região, considerando para os elementos-chave identificados, os possíveis benefícios para o Município de Cubatão e entorno.

Contudo, devem ser empreendidos estudos mais aprofundados de Avaliação de Impacto Ambiental e a contraposição destes com os impactos advindos do atual cenário, composto por excesso de caminhões, aumento da contaminação do ar, eliminação de fragmentos florestais para construção de pátios de estacionamento de caminhões ao longo da Serra do Mar e Planalto.

Também poderia ser considerada, em proposta também aventada neste estudo, a criação de uma central de controle única, que pudesse receber os sinais dos principais elementos-chave e auxiliar na tomada de decisão e planejamento. Essa proposta poderia ser observada para ações de curto prazo para controle, principalmente em casos em que se esteja próximo da ocorrência de episódios críticos de poluição do ar, e soluções imediatas sejam necessárias, como, interdições de pista, alteração de fluxo de vias, intensificação de umectação e redução da produção de alguns processos industriais. Estas ações já são previstas hoje, mas fazem-se necessárias adequações na tomada de decisão quanto à análise das condições do momento e o “timing” de implantação destas ações.

Para que a central única de controle possa ser operacional, faz-se necessário que os agentes presentes nesta central tenham expertise multidisciplinar, e estejam direcionados à gestão da região. Esta é a proposta diferencial e inovadora para o caso de se viabilizar uma central única de controle. Para tanto, a formalização desta estrutura seria necessária.

Próximas etapas envolveriam complementação de informações, busca de opiniões de especialistas em áreas correlatas para aprimoramento do protótipo, aumento do detalhamento de sistemas ou subsistemas críticos, para o atendimento aos requisitos, e divulgação da ideia buscando primeiramente visibilidade e ressonância dos interesses públicos e privados e, posteriormente, sua apresentação aos agentes que possibilitariam sua implementação.

É de interesse saber os impactos diretos e indiretos causados à economia nacional e local da Baixada. Nas informações que ainda deverão ser integradas ao projeto, destacase a quantificação de custos da obra e os benefícios que serão proporcionados por sua implantação. 
Os especialistas poderiam auxiliar na viabilidade técnica, econômica e ambiental do empreendimento, indicando possíveis alterações para melhorar a adequação e indicar demais contatos de interesse.

Após esta etapa, o projeto deverá ser submetido a uma nova etapa de adequações e detalhamento dos aspectos julgados mais importantes, para atendimento aos requisitos, podendo ser necessária análise suplementar.

Com estas etapas concluídas, a intenção é registrar por meio de documento em biblioteca, os avanços obtidos até o momento. Assim, a proposta final poderá ser divulgada ao grande público, pelos meios de comunicação e inscrição em concursos, de modo a verificar o apelo público que a implementação de tal solução poderia ter.

Quando se consideram os quatro elementos-chave para propor ações de gestão para o controle da poluição do ar no município de Cubatão, considerando-se também as propostas apresentadas, vê-se que existe o potencial para simular cenários, de forma a identificar possíveis alterações na qualidade do ar de forma antecipada, em função de novas diretrizes ou de alterações da dinâmica da região, para que sejam identificados os principais pontos a serem focados, estabelecendo objetivos, permitindo que, com estes, possa ser realizada uma avaliação das alterações necessárias ou complementação das ações de controle já existentes, para que então possam ser traçadas metas a serem alcançadas. 


\section{CAPÍTULO 4 - CONCLUSÕES E RECOMENDAÇÕES}

Cubatão tem uma realidade peculiar quando se trata de poluição, em especial, a poluição do ar. Uma vez que se tem uma nova dinâmica e atividade econômica na região é recomendado envolver, já nos primeiros momentos, as partes interessadas, quais sejam: os agentes ambientais e os pesquisadores. Observa-se nas discussões que a consciência ambiental permeia o senso comum de todos os segmentos da sociedade, porém, na prática da tomada de decisões, estas são tomadas individualmente.

Quando o momento crítico foi a poluição, foram envolvidos segmentos federais, estaduais e municipais, com grande envolvimento da CETESB, como o gestor do assunto. Agora, o momento vivenciado é gerido pela Logística. Viu-se que grupos e comissões foram formados, mas a discussão não envolveu de forma precisa as questões ambientais. Mesmo que, a princípio, não se enxergue uma grande contribuição do tráfego nas emissões atmosféricas, os agentes ambientais devem ser integrantes permanentes de uma “comissão de tendências e atividades de Cubatão”. Obviamente não devem também ser os gestores do assunto, mas a visão sobre as questões ambientais devem estar presentes em todas as propostas discutidas. Cubatão não tem espaço , seja no sentido geográfico ou social, para que sua imagem esteja atrelada a situações críticas e calamidades. É hora de Cubatão ser novamente um símbolo de superação e aliança com o restante das atividades desenvolvidas na região de seu entorno, porém desta vez, como a "alavanca” para novas alternativas de gestão, de novas ideias e ações preventivas e estar um passo à frente das mudanças.

A mobilização entre setores e municípios é importante para que percebam as necessidades e limitações de cada setor e possam, juntos, elaborar propostas para buscar soluções. Propõe-se que estas “comissões” sejam contínuas e as análises das situações sejam vistas à medida que os cenários se delineiem. A maioria das soluções leva tempo, o que acarreta um período de tempo de convívio com os problemas. A antecipação é prevista como princípio ambiental e deve eliminar ou minimizar o período de impacto que novos cenários podem trazer.

A realidade de cada região é muito diferente, o que torna a missão do Estado, em definir regulamentos e ações de controle, difícil. Não é viável utilizar uma única medida para diferentes realidades. Cada local ou região tem sua especificidade, tornando o controle da qualidade do ar mais simples ou complexo, conforme cada caso. As variações ou elementos-chave podem ser diferentes para cada localidade, e a aplicação de novas regras ou padrões de qualidade ambiental precisam identificar estas particularidades, em trabalho conjunto, multidisciplinar, multi-institucional e entre municípios, para melhoria da qualidade do ar.

Esta pesquisa ilustra que, ao longo do tempo, as alterações ocorridas levam à necessidade de que a forma com que se interpretam os índices monitorados seja reavaliada. 
Com base no que foi discutido anteriormente, confirma-se a hipótese de que as Políticas Públicas de Controle Ambiental são insuficientes para abranger a dinâmica atual do Município e seu entorno.

Da mesma forma, a hipótese de que os índices monitorados atualmente em Cubatão não consideram de forma efetiva outras fontes poluidoras, com destaque para as emissões decorrentes do tráfego de veículos, também foi estabelecida.

A análise do conjunto de ações relacionadas à gestão ambiental da qualidade do ar, no período de 1981 a 2013 no Município de Cubatão e seu entorno, considerando possibilidades de respostas na tomada de decisão e ações para controle da qualidade do ar, particularmente referente ao material particulado $\left(\mathrm{MP}_{10}\right)$, objetivo geral desta pesquisa, foi atingido.

Também, para que esta análise pudesse ser confrontada com a hipótese estabelecida, foi necessário que todos os objetivos específicos fossem atingidos. Desta forma, entendese:

- Que foram identificados e analisados os cenários de ocupação e dinâmica do Município de Cubatão e a evolução da qualidade do ar, considerando o parâmetro referente a material particulado $\left(\mathrm{MP}_{10}\right)$, entre 1981 a 2013. Com esta análise observou-se que as principais alterações ocorreram na região da antiga Vila Parisi, ou seja, ao longo do Polo Industrial de Cubatão.

- Que foram identificados e descritos 04 (quatro) elementos-chave para a região estudada, que possibilitaram caracterizar situações que interferem na qualidade do ar em Cubatão. Estes podem ser considerados para adoção no desenvolvimento de protótipos, estabelecimento de ações de gestão imediatas ou elaboração de estratégias de prevenção ou de mitigação. Os índices monitorados refletiram as consequências das alterações e ações adotadas na região, principalmente na região da Vila Parisi. Sendo assim, identificou-se que para a região, devem ser consideradas a inter-relação entre os elementos-chave no planejamento do desenvolvimento.

- Que, considerando os elementos-chave identificados, foi proposto, um protótipo para equacionar as questões associadas ao tráfego de caminhões e qualidade do ar em Cubatão e entorno, para o cenário atual da região.

A análise geral dos cenários leva a considerar que as ações de controle são adotadas apenas quando surgem os problemas. Identificou-se que estas ações de controle não são tratadas de forma estruturada e planejada quando da análise das propostas de mudanças de planos e estratégias de governo, como por exemplo, as diretrizes para ampliação de produção industrial, PRÉ-SAL, expansão portuária e, incentivo ao agronegócio. As consequências destas diretrizes foram percebidas pelas partes interessadas, mas as ações de gestão foram corretivas, buscando-se reverter uma situação, muitas vezes, já caótica. 
Uma vez que os resultados positivos foram alcançados, como a melhora dos índices da qualidade do ar, outros fatores como a melhora das condições do tráfego e as alterações da dinâmica da região, não passam por avaliações periódicas de uma forma conjunta.

Considerando os resultados e conclusões apresentadas, identificou-se que a cada tópico abordado, há necessidade de aprofundamento e detalhamento na aplicação e desenvolvimento dos conceitos apresentados.

As informações utilizadas foram qualitativas e foram agrupadas considerando as alterações de cenários, datas, percepções e relatos de documentos. Desta forma, apesar de que se considerou que estas informações foram muito úteis e apropriadas ao escopo desta pesquisa, estas não permitiram uma tratativa quantitativa neste momento.

Na proposta de desenvolvimento de alternativas para remoção do tráfego de caminhões próximos à estação da Vila Parisi, estas precisam ser identificadas e experimentadas. As ideias apresentadas necessitam de maiores estudos e planejamento, porém para as duas questões que hoje concorrem na região de Cubatão, quais sejam, tráfego intenso e emissões de particulados, pode ser proposto um recurso (ferramenta) de gestão mais ágil.

Observou-se também que as alterações significativas na dinâmica da região do Polo Industrial de Cubatão, têm ocorrido em intervalos de 30, 20 e 15 anos a cada cenário. As mudanças estão ocorrendo de forma cada vez mais rápida, o que reforça a necessidade de se identificar estas mudanças e propor tratativas a tempo. Desta forma, recomenda-se que, estas análises de cenários, devam ser realizadas periodicamente. Propõe-se, portanto, que a cada 5 anos, sejam reavaliadas as condições do local de forma que as ações adotadas possam ser revistas e implantadas de forma estruturada e menos subjetiva, para que um planejamento e adoção de ações efetivas possam ser realizadas.

A revisão do cenário deve avaliar e propor ações necessárias, tanto para reforço das ações existentes, eliminação daquelas que não sejam mais compatíveis com a situação, realocação ou aumento de pontos de monitoramento de parâmetros de qualidade do ar, mudanças de trajeto, necessidades de infraestrutura diferenciada, entre outras.

Não se pretende orientar ou estabelecer critérios para a utilização dos índices extraídos das estações medidoras, e menos ainda propor que estes índices de qualidade do ar sejam eliminados. Estes índices são extremamente importantes. O que se propõe, são novas formas de avaliar as circunstâncias do entorno, com uma participação de equipe multidisciplinar, avaliar a necessidade de aumento da malha de monitoramento de forma a buscar maior representatividade em função das alterações identificadas na região do Polo Industrial de Cubatão e eventualmente, uma revisão da legislação aplicável. 


\section{REFERÊNCIAS}

II Plano Nacional de Desenvolvimento (PND), 2012. Disponível em

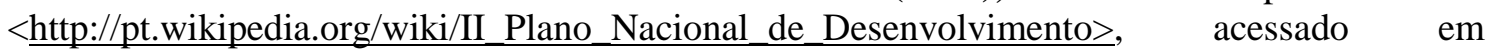
01/03/2015.

ANUATTI-NETO, F; BAROSSI FILHO, M; CARVALHO, AG; MACEDO, R. Os efeitos da privatização sobre o desempenho econômico e financeiro das empresas privatizadas. Revista Brasileira de Economia, Vol. 59, n²2 , Rio de Janeiro, Apr/June 2005. Disponível em <http://www.scielo.br/scielo.php?script=sci_arttext\&pid=S0034-71402005000200001> acessado em 17/04/2015

ASSUNÇÃO, J.V.,

Poluição do ar - alguns conceitos, Departamento de Saúde Ambiental, USP/FSP, disponibilizado em disciplina da Pós-Graduação Mestrado Profissional em Ambiente, Saúde e Sustentabilidade, em 2014.

BALBINO, H.T. Avaliação de modelos fotoquímicos de qualidade do ar e estudo das circulações atmosféricas nos processos de dispersão de poluentes. v.1. 2008. Dissertação (Mestrado em Ciências Atmosféricas) - Departamento de Ciências Atmosféricas. São Paulo, SP.

BARNEY, O.G.; EBERLEIN, R.; QU, W.; SHARMA, P.D. The Threshold 21Sustainable Development Model..Arlington, Virginia (USA).Systems Dynamics '95-Volume I. 1995. Pp. 23 a 29.

BARROS, Z. Multas afastam caminhões de vias para o Porto de Santos. AGÊNCIA ESTADO, fev. 2014. Disponível em < http://exame.abril.com.br/brasil/noticias/multas-afastamcaminhoes-de-vias-para-o-porto-de-santos $>$, acesso em 09/03/2014.

BRASIL. Conselho Nacional do Meio Ambiente. Resolução CONAMA 03/1990, de 28 de junho de 1990. Dispõe sobre padrões de qualidade do ar, previstos no PRONAR. Diário Oficial [da] República Federativa do Brasil, Brasília, DF, 22 ago. 1990. Seção 1, p. 15937-15939.

BRASIL. Resolução CONAMA no 5 de 15/06/89, institui o Programa Nacional de Controle da Qualidade do $\mathrm{Ar}$ - PRONAR, como um dos instrumentos básicos da gestão ambiental para proteção da saúde e bem estar das populações e melhoria da qualidade de vida com o objetivo de permitir o desenvolvimento econômico e social do país de forma ambientalmente segura, pela limitação dos níveis de emissão de poluentes por fontes de poluição atmosférica,

BRASIL. RESOLUÇÃo CONAMA nº 18, de 6 de maio de 1986, Dispõe sobre a criação do Programa de Controle de Poluição do Ar por veículos Automotores - PROCONVE.

BRIDGESTONE. Products. Pipe Conveyor belt. Disponível em $<$ http://www.bridgestone.com/products/diversified/conveyorbelt/products/pipe_conveyor_belt.ht $\underline{m l}>.2014$.

CALABREZI, S. R. S. A multimodalidade para o transporte de cargas: identificação de problemas em terminais visando à integração dos modais aéreo e rodoviário. 2005. $139 \mathrm{f}$. Dissertação (Mestrado em Engenharia Civil) - Faculdade de Engenharia Civil, Arquitetura e Urbanismo, Universidade Estadual de Campinas, Campinas, 2005. 
CASTRO, C. $\mathrm{O}$ Golpe de 1964, s/d. Disponível em < http://cpdoc.fgv.br/producao/dossies/FatosImagens/Golpe1964>, acessado em 18/01/2015.

CETESB - sítio eletrônico. Disponível em <http://www.cetesb.sp.gov.br>.

CETESB 1996 - Comportamento sazonal da poluição do ar em São Paulo - Análise de 14 anos de dados da RMSP e Cubatão - 1981 a 1994 (1996), disponível em http://www.cetesb.sp.gov.br/ar/qualidade-do-ar/31-publicacoes-e-relatorios (tabela - outros relatórios).

CETESB, 1998a - Amônia na atmosfera de Cubatão. 1998. Disponível em $<$ http://www.cetesb.sp.gov.br/ar/qualidade-do-ar/31-publicacoes-e-relatorios>.

CETESB, 1998b - Fluoretos na atmosfera de Cubatão. 1998. Disponível em $<$ http://www.cetesb.sp.gov.br/ar/qualidade-do-ar/31-publicacoes-e-relatorios $>$.

CETESB - serie a - Relatórios de qualidade do ar - - 1985 a 2013, disponível em http://www.cetesb.sp.gov.br/ar/qualidade-do-ar/31-publicacoes-e-relatorios (tabela - relatórios da qualidade do ar no Estado de São Paulo).

CETESB - serie b - Relatórios da operação inverno - 2004 a 2013, disponível em http://www.cetesb.sp.gov.br/ar/qualidade-do-ar/31-publicacoes-e-relatorios (tabela - operação inverno)

CETESB - serie c - Relatórios de emissões veiculares - 2011 e 2013, disponível em http://www.cetesb.sp.gov.br/ar/emissao-veicular/48-relatorios-e-publicacoes

CETESB 2013 d - Classificação preliminar da representatividade espacial das estações de monitoramento da qualidade do ar da CETESB no Estado de São Paulo - Julho/2013, disponível em http://www.cetesb.sp.gov.br/ar/qualidade-do-ar/31-publicacoes-e-relatorios (tabela - outros relatórios)

CETESB 2014a - PREFE - Plano de redução de emissão de fontes estacionarias [recurso eletronico]: Anexo G - Estimativa de emissão de material particulado gerada pelo tráfego de caminhões em Cubatão - Informação Técnica nº 04/14/ETHA . PREFE 2014. Disponível em $<$ http://www.cetesb.sp.gov.br>,

CETESB 2014b - PCPV- Plano de Controle de Poluição Veicular- 2014 - 2016 [recurso eletrônico]: PCPV Jun/2014. Disponível em <http://www.cetesb.sp.gov.br>

CIDE - Centro de Integração e Desenvolvimento Empresarial da Baixada Santista. Polo Industrial de Cubatão. Cubatão 2020 - A cidade que queremos - Agenda 21, Cubatão, SP, 2006, disponibilizado por CIESP Cubatão.

CIESP 2012 - Centro das Indústrias do Estado de São Paulo. Polo Industrial de Cubatão. "Relatório da Comissão de Logística - Cubatão - Estudo de movimentação de cargas no Polo - 2004, 2005, 2006, 2007, 2008 e 2011”, Cubatão, SP, 2012, disponibilizado por CIESPRegional Cubatão. 
CIESP 2013a - Centro das Indústrias do Estado de São Paulo. Polo Industrial de Cubatão. Apresentação de abertura da operação inverno 2013, Cubatão, SP, maio 2013, disponibilizado por CIESP-Regional Cubatão.

CIESP 2013b - Centro das Indústrias do Estado de São Paulo. Polo Industrial de Cubatão. Apresentação de encerramento da operação inverno 2013, Cubatão, SP, outubro 2013, disponibilizado por CIESP-Regional Cubatão.

COELHO, C.D. Análise dos contaminantes biológicos presentes no material particulado $\left(\mathbf{M P}_{2,5}\right)$ de amostras da região metropolitana de São Paulo. 2009. Tese. (Doutorado em Ciências) - Faculdade de Medicina, Universidade de São Paulo, São Paulo.

COLOMBINI, M.P. Exposição aguda ao material particulado total em suspensão proveniente de diferentes fontes e suas repercussões nas respostas inflamatórias, sistêmica e local, em ratos. 2007. Tese (Doutorado em Medicina) - Faculdade de Medicina Departamento de Patologia, Universidade de São Paulo, São Paulo.

CORREA, V.H.C.; RAMOS, P. A Precariedade do Transporte Rodoviário Brasileiro para o Escoamento da Produção de Soja do Centro-Oeste: situação e perspectivas. RESR, Piracicaba, SP, vol. 48, nº 02, p. 447-472, abr/jun 2010 .

COUTO, J.M. Entre estatais e transnacionais: o Polo industrial de Cubatão. Tese (Doutorado) - Unicamp, 2003.

CRUZ, F. Movimento no Porto de Santos cresceu 9\% em 2013. AGÊNCIA BRASIL, jan 2014. Disponível em <http://exame.abril.com.br/economia/noticias/movimento-no-porto-desantos-cresceu-9-em-2013>. Acesso em 09/03/2014.

CUMMING, G.S. Scale mismatches and reflexive law. 2013. Ecology and Society 18(1): 15. Disponível em <http://dx.doi.org/10.5751/ES-05407-180115>. Artigo disponibilizado em disciplina do mestrado profissional em Ambiente, Saúde e Sustentabilidade, em 2014.

D'ARAUJO, M.C. $\quad$ O $\quad$ AI5, s/d. Disponível em < http://cpdoc.fgv.br/producao/dossies/FatosImagens/AI5>, acessado em 18/01/2015.

ECOVIAS. Ecovias estima mais de $\mathbf{4 5 0}$ mil veículos nos feriados de Natal e Ano Novo. 2013, disponível em <http://www.ecovias.com.br >, p. publicado em 20/12/2013, acesso em 13/08/2014. (transito final de ano - ecovias Blog.htm)

ELOG. Gestão de Logística Integrada - Elog Cubatão. Disponível em $<$ http://www.eloglogistica.com.br/Unidades/Cubatao $>$, acesso em 22/01/2014.

ECOPATIO Cubatão, Imagens, s/d Disponível em $<$ http://extapps.mzir.com/Ecorodovias/RAO/2010/port/ra/14.htm>, acessado em 22/01/2014.

FERLING, F. F. Gestão de bacias aéreas como instrumento de gestão ambiental: estudo de caso em projetos de geração de energia no Estado de São Paulo. 2008.127 p. Dissertação. (Mestrado em energia) - Escola Politécnica/Escola de Economia e Administração/Instituto de Eletrotécnica e Energia/Instituto de Física, Universidade de São Paulo, São Paulo. 
FERREIRA, L.G. A gestão ambiental do pólo industrial de Cubatão a partir do programa de controle de poluição iniciado em 1983: atores, instrumentos e indicadores. 2007.289 p. Dissertação. (Mestrado em Saúde Pública) - Faculdade de Saúde Pública, Universidade de São Paulo, São Paulo.

FIESP/CIESP - Federação das Indústrias do Estado de São Paulo/Centro das Indústrias do Estado de São Paulo. A recuperação ambiental de Cubatão - 25 anos. .2008. Apresentação realizada em Cubatão, disponibilizada pelo CIESP- regional Cubatão.

FIGUEIREDO, B.; FERRACIOLI, E.A.; FERREIRA, F. P.; PEREIRA, P.; TENGUAN, P.M.; 2014. Sistema logístico de transporte no eixo São Paulo - Cubatão - Santos e sua relação com a qualidade do ar . Relatório final da disciplina "Desenvolvimento de Produto Integrado”, da Universidade de São Paulo - Escola Politécnica, 2014.

FREITAS, A.H.A. Gestão ambiental com auxílio de avaliação integrada de riscos. 2006. 115 p. Dissertação (Mestrado em Engenharia) - Escola Politécnica da Universidade de São Paulo, São Paulo.

FURLAN, C.M. Efeitos da poluição aérea de Cubatão sobre o conteúdo de nitrogênio, fibras, ligninas e substâncias fenólicas foliares e atividade herbivórica em Tibouchina pulchra Cogn..1998. Dissertação (Mestre em Ecologia)- Departamento de Ecologia Geral do Instituto de Biociências da Universidade de São Paulo .

G1 A Tribuna- Santos e região. Fotos: estradas do litoral registram longo congestionamento. 2013. Disponível em < http://glo.bo/18q9zOr $>$, acesso em 13/08/2014.

GIARETTA, J.B.Z. Participação Social e Gestão Ambiental Municipal no Brasil: Desafios e Condicionantes. 2011. 157p. Dissertação (Mestrado em Ciências) - Faculdade de Saúde Pública, universidade de São Paulo, São Paulo.

GIBSON, R.B. Beyond the pillars: Sustainability assessment as a framework for effective integration of social, economic and ecological considerations in significant decision-making. 2006. Journal of Environmental Assessment Policy and Management

Vol. 8, No. 3 (September 2006) pp. 259-280. (C) Imperial College Press.

GUANABARA a, A.P.S. Associação da função pulmonar em estudantes do ensino fundamental com a qualidade do ar nas cidades de Atibaia e Cubatão. 2011. São Paulo, SP. Dissertação (Mestre em Saúde Pública) - Faculdade de Saúde Pública, Universidade de São Paulo, São Paulo.

GUANABARA b, L.C.R. Associação da função pulmonar de indivíduos fumantes e não fumantes com a qualidade do ar, nas cidades de Cubatão e Bertioga. 2011. São Paulo, SP. Dissertação (Mestre em Ciências) - Faculdade de Saúde Pública, Universidade de São Paulo, São Paulo.

HABERMANN, M.; MEDEIROS, A.P.P.; GOUVEIA, N. Tráfego veicular como método de avaliação da exposição à poluição atmosférica nas grandes metrópoles. 2011. Revista Brasileira de Epidemiologia 2011, 14(1):120-30. 
HABERMANN, M. Métodos de avaliação da exposição ambiental aos poluentes atmosféricos gerados por tráfego veicular. 2012. 125p. Tese (Doutorado em Ciências) Faculdade de Medicina, Universidade de São Paulo, São Paulo.

HABERMANN, M.; MEDEIROS, A.P.P.; GOUVEIA, N. Aplicação de regressão baseada no uso do solo para predizer a concentração de material particulado inalável no município de São Paulo, Brasil. 2012. Engenharia Sanitária Ambiental 2012, v.17 n.2, abr/jun 2012: 155162.

HADDAD, C.L. Direito e educação ambiental: um diálogo entre o dever ser da norma jurídica estatal e o dever ser de quem deve cumpri-la. 2007. 135 p. Dissertação. (Mestrado em Ecologia Aplicada) - Escola Superior de Agricultura "Luiz de Queiroz" - Centro de Energia Nuclear na Agricultura, Universidade de São Paulo, Piracicaba.

HIJJAR, M. F. Logística, soja e comércio internacional. Centro de Estudo em; 2004

JONES, T.; GLASSON, J.; WOOD, D.; FULTON, E. Regional Planning and Resilient

Futures: Destination Modelling and Tourism Development-The Case of the Ningaloo Coastal Region in Western Australia. 2011 downloaded by: [Curtin University of

Technology], on: 11 September 2011, at: 18:09. Publisher: Routledge Informa Ltd Registered in England and Wales Registered Number: 1072954 Registered office: Mortimer House, 37-41

Mortimer Street, London W1T 3JH, UK.

JORNAL A TRIBUNA SANTOS. Codesp e SEP darão coletiva sobre congestionamentos nas vias de acesso à Baixada Santista. 2014. Disponível em http://www.atribuna.com.br/noticias/noticias-detalhe/cidades>, acesso em 18/02/2014.

KIElinG, A. P.; KAUling, G. B.; MULleR, J. M.; FIALHO, F. A. P. . Aspectos Interdisciplinares em Design Thinking - um enfoque na Administração de Negócios, Moda e Psicologia Social. In: Simpósio Internacional sobre Interdisciplinaridade no Ensino, na Pesquisa e na Extensão - Região Sul, 2013, Florianópolis. Simpósio Internacional sobre Interdisciplinaridade no Ensino, na Pesquisa e na Extensão - Região Sul, 2013. p. 1-13

LEMOS, J.F. Poluição veicular: avaliação dos impactos e benefícios ambientais com a renovação da frota veicular leve na cidade de São Paulo. 2010. 133p. Dissertação (Mestrado em energia). Escola Politécnica/Escola de Economia e Administração/Instituto de Eletrotécnica e Energia/Instituto de Física, Universidade de São Paulo, São Paulo.

LOPES, M.I.M.S. Fluxo de água, balanço químico e alterações no solo da Floresta Atlântica atingida pela poluição aérea de Cubatão, SP, Brasil. 2001. 188 p. Tese (Doutorado em Ciências) - Instituto de Biociências, Universidade de São Paulo, São Paulo.

LOPES, F. O desafio da hiperinflação. Rio de Janeiro: Ed Campus, 1989.

MAGLIO, I.C. A sustentabilidade ambiental no planejamento urbano do Município de São Paulo: 1971 - 2004. 2005. 406 p. Tese (Doutorado em Saúde Pública) - Faculdade de Saúde pública, universidade de São Paulo, São Paulo.

MANAHAN, S.E. Environmental Chemistry. 8th ed. Florida. CRC Press LLC, 2005, p. 279. 
MARRO, A.A.; SOUZA, A.M.C.; CAVALCANTE, E.R.S.; BEZERRA, G.S.; NUNES, R.O. Lógica Fuzzy: Conceitos e aplicações. 2009. Disponível em < https://scholar.google.com.br/citations?user=qD-QQrsAAAAJ\&hl=pt-BR\&oi=sra $>$. Acesso em $\mathrm{jul} / 2014$.

MARTINS, A.P.G. Cascas de árvores como biomonitores da poluição atmosférica de origem veicular em parques urbanos da cidade de São Paulo. 2009. Tese. (Doutorado em Ciências) - Faculdade de Medicina, Universidade de São Paulo, São Paulo.

MANTEgA, G. O Governo Geisel, o II PND e os Economistas. 1997. EAESP-FGV. Relatório de Pesquisa ${ }^{0} 3$.

MOREIRA, R.L. CSN: Uma decisão política. disponível em http://cpdoc.fgv.br/producao/dossies/FatosImagens/CSN/ acessado em 18/01/2015/

NASCIMENTO, K.H. Determinação de compostos orgânicos no aerossol atmosférico em sítios da América do Sul. 2010. 140 p. Dissertação (Mestre em Química) - Instituto de Química, Universidade de São Paulo, São Paulo.

NATALI, L. Utilização dos produtos obtidos por sensoriamento remoto na caracterização da qualidade do ar na Região Metropolitana de São Paulo. 2008. São Paulo, SP. Dissertação (Mestre em Ciências : área de concentração meteorologia) - Departamento de Ciências Atmosféricas do instituto de Astronomia, Geofísica e Ciências Atmosféricas , Universidade de São Paulo, São Paulo.

NOVO MILÊNIO - Histórias e lendas de Cubatão, 2014. Disponível em $<$ http://www.novomilenio.inf.br/cubatao/ch014e.htm>, acesso em 13/08/2014.

NUNES, M.R. A atuação dos Conselhos Municipais do Meio Ambiente na gestão ambiental local. 2010. 158 p. Dissertação (Mestrado em Ciências). Faculdade de Saúde Pública, Universidade de São Paulo, São Paulo.

OGLIARI, K.S. Efeitos intra-uterinos e pós-natais da exposição crônica ao combustível diesel sobre o aparelho reprodutor feminino. 2011. São Paulo, SP. Tese (Doutorado em Ciências) - Faculdade de Medicina da Universidade de São Paulo - Programa de Patologia) USP/FM/DBD-232/11.

PEREIRA, L.F.; MAIA,N.M.A.; PEREIRA,W.F. A importância do investimento em pátios reguladores de caminhões nos portos brasileiros. Apresentado no $15^{\circ}$ Congresso Brasileiro de Transporte e Transito, Agosto/2005 Disponível em file://C:/Users/USUARIO/Downloads/Artigo\%20Patio\%20em\%20Porto\%20Congresso\%20A NTP\%20Goiania.pdf > acessado em 22/01/2014.

PIRES, F. "Vale da Morte” foi o símbolo de Cubatão. Matéria publicada em 15/03/2012 na REVISTA VALOR ECONÔMICO, mar/2012, disponível em < www.valor.com.br/brasil/.../vale-da-morte-foi-o-simbolo-de-cubatao $>$, acesso em jan/2014.

PREFEITURA MUNICIPAL DE CUBATÃO - Aspectos econômicos, 2014 a. Disponível em $<$ http://www.cubatao.sp.gov.br/historia/cidade/aspectos-economicos/> acessado em $19 / 01 / 2014$ 
PREFEITURA MUNICIPAL DE CUBATÃO - Aspectos geográficos, 2014 b. Disponível em $<$ http://www.cubatao.sp.gov.br/historia/cidade/aspectos-geograficos/> acessado em 19/01/2014.

PREFEITURA MUNICIPAL DE CUBATÃO - Origem e desenvolvimento, 2014 c. Disponível em < www.cubatao.sp.gov.br/historia/origem-desenvolvimento/> acessado em 19/01/2014.

POPE, J.; BOND, A.; MORRISON-SAUNDERS, A.; RETIEF, F. Advancing the theory and practice of impact assessment: Setting the research agenda. 2013. Environmental Impact Assessment Review 41 (2013) 1-9. Contents lists available at SciVerse ScienceDirect. Disponível em <journal homepage: www.elsevier.com/locate/eiar>.

REUTERS Domestic. Medidas contra filas em Santos esbarram em safra recorde. 2014. Disponível em <http://exame.abril.com.br/economia/noticias/medidas-contra-filas-em-santosesbarram-em-safra-recorde-gargalos-e-desrespeito-2> Acesso em 09/03/2014.

RIBEIRO, A.A. Estudo de correlação das internações hospitalares por câncer, poluição relacionada ao tráfego e nível sócio-econômico no município de São Paulo. 2011. Dissertação (Mestrado em Ciências) - Faculdade de Saúde Pública, Universidade de São Paulo, São Paulo.

RODRIGUES, O. A década perdida: 1980. 2005. Disponível em < http:// www.coladaweb.com/ década perdida 1980>acessado em 19/09/2014 .

SANTOS, E. L. dos. Avaliação do “conceito bolha” como critério de compensação ambiental em atividades poluidoras do ar atmosférico - estudo de caso no estado de São Paulo. 2004. Dissertação (Mestrado em Engenharia Urbana) - Universidade Federal de São Carlos, São Carlos, São Paulo.

SANTOS, F.C. dos. Determinação dos compostos orgânicos nos materiais particulados (MP $\left.\mathbf{1 0}_{0}\right)$ Atmosféricos no estado de São Paulo. 2010. 110 p. Dissertação (Mestrado em Química) - Instituto de Química, Universidade de São Paulo, São Paulo.

SANTOS, F.S. A construção de material didático contextualizado como subsídio para as aulas de Ciências do Ensino Fundamental (II): Uma experiência colaborativa em Cubatão, SP. 2009. 323p. Tese (Doutorado em Educação) - Faculdade de Educação, Universidade de São Paulo, São Paulo.

SÃO PAULO (Estado). Lei $\mathbf{n}^{\circ}$ 118, de 29 de junho de 1973. Autorizaa constituição de uma sociedade por ações, sob a denominação de CETESB - Companhia de Tecnologia de Saneamento Básico e de Controle da Poluição das Águas, e dá providências correlatas.

SÃO PAULO (Estado). Lei $\mathbf{n}^{\circ}$ 997, de 31 de maio de 1976. Dispõe sobre o Controle da Poluição do Meio Ambiente.

SÃO PAULO (Estado), Decreto Estadual no 8.468, de 08 de setembro de 1976. Aprova o Regulamento da Lei n ${ }^{\circ}$ 997, de 31 de maio de 1976, que dispõe sobre a Prevenção e o Controle da Poluição do Meio Ambiente. 
SÃO PAULO (Estado), Decreto Estadual n 26.942, de 01 de abril de 1987.

SÃO PAULO (Estado). Lei 13.542 , de 08 de maio de 2009. Altera a denominação da CETESB - Companhia de Tecnologia de Saneamento Ambiental e dá nova redação aos artigos $2^{\circ}$ e 10 da Lei no 118, de 29 de junho de 1973.

SÃO PAULO (Estado). Decreto 59.113, 23 de abril de 2013. Estabelece novos padrões de qualidade do ar e dá providências correlatas. Diário Oficial [do] Estado de São Paulo,São Paulo, 24 abr. 2013, Poder Executivo, Seção I, p.1-4

SECRETARIA DA HABITAÇÃO/SECRETARIA DE MEIO AMBIENTE - Projeto de desenvolvimento sustentável do Litoral Paulista, ano 2013, apresentação disponibilizada por meio eletrônico para membro do comitê de zoneamento ecológico-econômico da Baixada Santista.(ZEE-BS)

SERENZA, E. CETESB inaugura central de monitoramento "on line" e estação telemétrica em Cubatão. Cubatão, SP, set. 2004, disponível em < http://www.cetesb.sp.gov.br/noticentro/004/09/24_telemetrica.htm>, acesso em 15/05/2013.

SILVA, M. F. Emissão de metais por veículos automotores e seus efeitos à saúde pública. 2007. Dissertação (Mestrado em Saúde Pública) - Faculdade de Saúde Pública, Universidade de São Paulo, São Paulo.

SILVA, E.N. Ambientes atmosféricos intraurbanos na Cidade de São Paulo e possíveis correlações com doenças dos aparelhos : respiratório e circulatório. 2010. Tese (Doutorado em Saúde Pública)- Faculdade de Saúde Pública, Universidade de São Paulo, São Paulo.

SILVA, M. F. Reatividade fotoquímica da atmosfera de Cubatão e a influência de fontes exógenas. 2013. 256 p. Tese (Doutorado em Ciências) - Faculdade de Saúde Pública, Universidade de São Paulo, São Paulo.

SOGABE, V. P. Caracterização do desempenho operacional em terminais intermodais de escoamento de grãos: um estudo multicaso no corredor Centro-Oeste. 2010. $122 \mathrm{f}$ Dissertação (Mestrado em Administração) - Departamento de Economia e Administração, Universidade Federal de Mato Grosso do Sul, Campo Grande.

TOLEDO, G.I.F.M. Avaliação da exposição da população à poluição relacionada ao tráfego no município de São Paulo. 2010. 111 p. Tese (Doutorado em Saúde Pública) - Faculdade de Saúde Pública, Universidade de São Paulo, São Paulo.

USP/FSP. Guia de apresentação de teses. 2. ed. atual. on line. São Paulo: A Biblioteca, 2008. Disponível em: http:www.bibcir.fsp.usp.br.

VALARINI, S. Caracterização do material particulado em Cubatão. 2011. 134 p. Dissertação (Mestrado em Ciências) - Instituto de Astronomia, Geofísica e Ciências Atmosféricas, Universidade de são Paulo, São Paulo.

VEJA Revista eletrônica. Filas no Porto de Santos congestionam estradas. 2013. Disponível em < http:// VEJA.com.br>, acesso em 13/08/2014. 
VENDRAMINI, P.R.R.J. A participação em conselhos como instrumento de gestão municipal. 2010. Tese (Doutor em Ciência). Faculdade de Saúde Pública, São Paulo, SP.

WAZE. 2015. Disponível em:_http://pt.wikipedia.org/wiki/Waze>, acesso em 15/06/2015

YANAGI, Y. Estudo da influência do material particulado na incidência e mortalidade por câncer na cidade de São Paulo. 2010. Dissertação (Mestrado em Saúde Pública) - Faculdade de Saúde Pública, São Paulo, SP.

ZANCUL, E.S.; LOPES, R.D.; NAKANO, D.N.;FLEURY, A.L. Disciplina de formação para a inovação, com base em projeto multidisciplinar e prototipação de soluções complexas para problemas reais da sociedade. 2014. Apresentação realizada no III Simposio Tematico da Pró-Reitoria de Graduação - A Docência na USP: desafios e inovações. Disponível em http://www.prg.usp.br/?page_id=16662 
APÊNDICE A - CONSOLIDAÇÃO DOS FATOS HISTÓRICOS DE CUBATÃO E SUAS CONSEQUÊNCIAS 


\begin{tabular}{|c|c|c|c|c|}
\hline \multicolumn{5}{|c|}{ CONSOLIDAÇÃO DOS FATOS HISTÓRICOS DE CUBATÃO E CONSEQUÊNCIAS } \\
\hline Período & Função & Dinâmica & Fatos & Consequências \\
\hline $\begin{array}{ll}\text { Séc. } & \text { XVI } \\
- & \text { Séc. } \\
\text { XIX } & \end{array}$ & $\begin{array}{l}\text { Portuária } \\
\text { Passagem } \\
\text { Ambiental }\end{array}$ & & $\begin{array}{l}\text { - Porto Geral de Cubatão } \\
\text { - Interligação entre litoral e Planalto - mulas } \\
\text { - Atividades compatíveis com o meio } \\
\text { ambiente }\end{array}$ & $\begin{array}{l}\text { Desenvolvimento local } \\
\text { Assentamentos/Povoado } \\
\text { Vila /Município }\end{array}$ \\
\hline $\begin{array}{ll}\text { Séc. } & \text { XIX } \\
- & \text { Séc. } \\
\text { XX } & \end{array}$ & $\begin{array}{l}\text { Portuária } \\
\text { Passagem } \\
\text { Agrícola } \\
\text { Industrial } \\
\text { Ambiental }\end{array}$ & & $\begin{array}{l}\text { - Implantação da ferrovia } \\
\text { - Movimentação até Porto de Santos } \\
\text { - Cultivo da banana } \\
\text { - Início da industrialização } \\
\text { - Atividades compatíveis com o meio } \\
\text { ambiente }\end{array}$ & $\begin{array}{ll} & \text { Desenvolvimento local } \\
\text { - } & \text { Transporte de mercadorias facilitado } \\
\text { - } & \text { Declínio porto de Cubatão } \\
\text { - } & \text { Aumento de ocupação área agrícola } \\
\text { - } & \text { Curtumes }\end{array}$ \\
\hline $\begin{array}{l}1921 \\
1950\end{array}$ & $\begin{array}{l}\text { Agrícola } \\
\text { Passagem } \\
\text { Industrial } \\
\text { Ambiental }\end{array}$ & & $\begin{array}{l}\text { - Cultura banana permanece (foco menos } \\
\text { intenso) } \\
\text { - Construção da Via Anchieta } \\
\text { - } \quad \text { Instalação hidrelétrica Light /Cia. Santista de } \\
\text { Papel } \\
\text { - } \\
\text { Assentamentos nas encostas. }\end{array}$ & $\begin{array}{l}\text { Desenvolvimento local/Regional } \\
\text { - } \quad \begin{array}{l}\text { Deslocamento de mão de obra para } \\
\text { indústrias e construção da estrada. } \\
\text { - }\end{array} \text { Aumento do tráfego pelas estradas - } \\
\text { cargas para o Porto de Santos. } \\
\text { - } \quad \begin{array}{l}\text { Desenvolvimento industrial/Vilas } \\
\text { operárias afastadas do centro }\end{array} \\
\text { - Atividades da região compatíveis } \\
\text { sinalizando interferências no ambiente. }\end{array}$ \\
\hline
\end{tabular}




\begin{tabular}{|c|c|c|c|c|}
\hline Período & Função & Dinâmica & Fatos & Consequências \\
\hline $\begin{array}{l}1951 \\
1970\end{array}$ & $\begin{array}{l}\text { Passagem/Logística } \\
\text { Agrícola } \\
\text { Ambiental }\end{array}$ & & $\begin{array}{l}\text { - Usina elétrica subterrânea de Cubatão } \\
\text { (Henry Borden) } \\
\text { - PND - "milagre econômico” - “interesse } \\
\text { nacional” } \\
\text { - Instalação e consolidação do Polo Industrial } \\
\text { de Cubatão (1955 -1970) } \\
\text { - Aumento do tráfego de caminhões - } \\
\text { indústrias. } \\
\text { - Utilização das áreas agrícolas para } \\
\text { implantação das indústrias. } \\
\text { Emissões das indústrias; instalação de vilas } \\
\text { operárias próximas às unidades (fase de } \\
\text { construção e operação). }\end{array}$ & $\begin{array}{l}\text { Desenvolvimento regional/nacional } \\
\text { - } \text { Aumento da oferta de energia elétrica } \\
\text { - } \text { Cubatão - localização estratégica. } \\
\text { - } \text { Estatização das indústrias de base - } \\
\text { - Tráfego compara nacional } \\
\text { via, porém mais intenso a capacidade da } \\
\text { - Mão de obra local deslocada para } \\
\text { - } \text { Atividade agrícola em declínio } \\
\text { - Na década de } 1960 \text { já começam as } \\
\text { primeiras reclamações devido aos efeitos } \\
\text { da poluição. }\end{array}$ \\
\hline $\begin{array}{l}1971 \\
1980\end{array}$ & 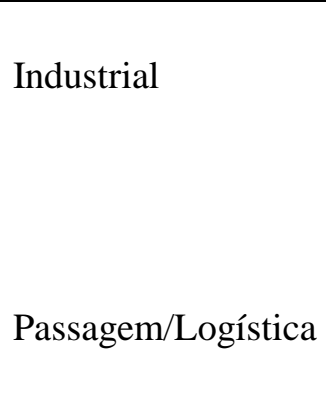 & 0 & $\begin{array}{l}\text { - } \text { Brasil - política desenvolvimentista } \\
\text { - Crise econômica internacional } \\
\text { - Regime militar - gestão de estatais } \\
\text { - Indústria automobilística } \\
\text { desenvolvimento em }\end{array}$ & $\begin{array}{l}\text { Desenvolvimento regional/nacional } \\
\text { - Investimentos do Governo } \\
\text { - Sinaliza o fim do "milagre econômico" } \\
\text { - Limitação de atuação dos órgãos } \\
\text { ambientais em favor do desenvolvimento } \\
\text { - Tráfego ainda compatível com a atividade } \\
\text { da região }\end{array}$ \\
\hline & Ambiental & & $\begin{array}{l}\text { - Conscientização mundial - Conferência de } \\
\text { Estocolmo (1972) } \\
\text { - Cubatão - "Vale da Morte” }\end{array}$ & 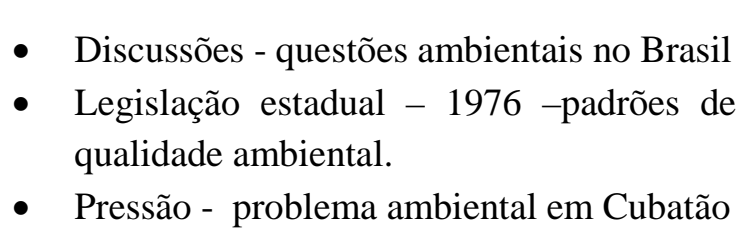 \\
\hline
\end{tabular}




\begin{tabular}{|c|c|c|c|c|}
\hline Período & Função & Dinâmica & Fatos & Consequências \\
\hline $\begin{array}{l}1981 \\
1990\end{array}$ & 更 & $\square$ & $\begin{array}{l}\text { - Crise do petróleo - internacional } \\
\text { - Governo mantém a intensa atividade } \\
\text { industrial } \\
\text { - } \text { Corte dos gastos públicos } \\
\text { - } \text { Mestrições de importação } \\
\text { centros urbanos } \\
\text { - Tráfego intenso } \\
\text { - Resposta aos eventos de poluição em } \\
\text { Cubatão - plano de objetivos e metas } \\
\text { Em paralelo a proposta de ações imediatas e } \\
\text { emergenciais para Cubatão. } \\
\text { CETESB - Aplicação dos padrões de } \\
\text { qualidade do ar e episódios críticos de } \\
\text { poluição do ar. }\end{array}$ & 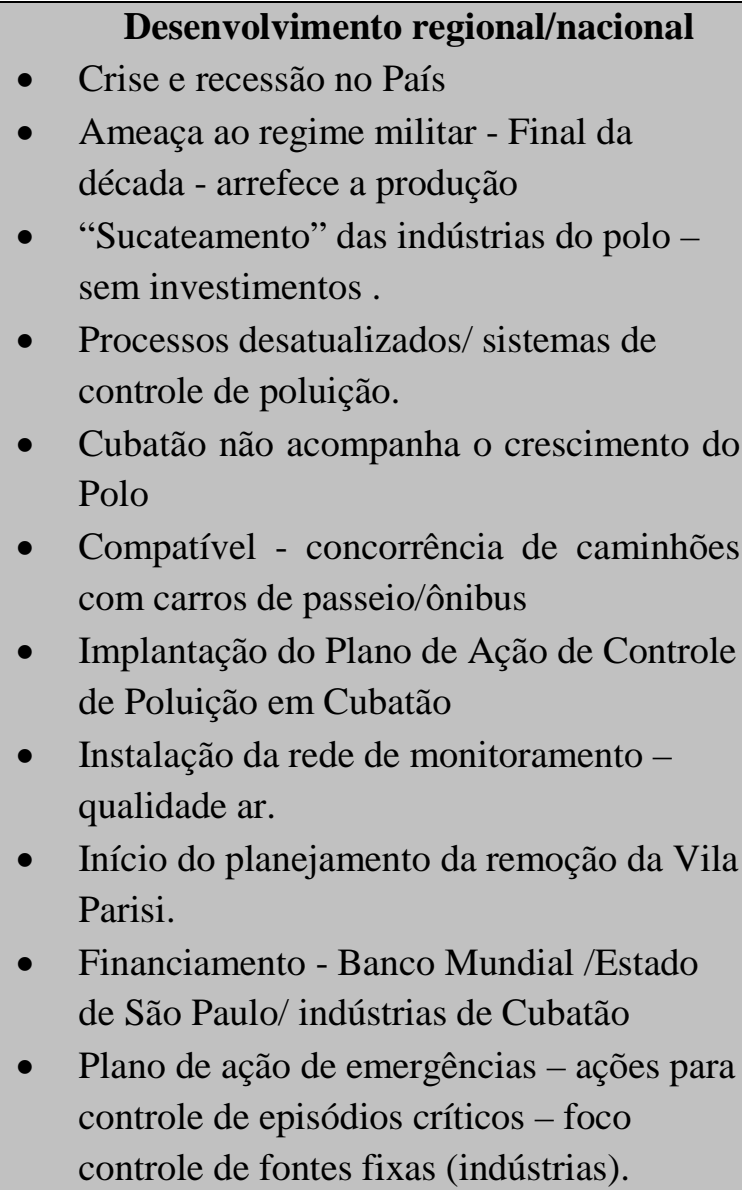 \\
\hline
\end{tabular}




\begin{tabular}{|c|c|c|c|c|}
\hline Período & Função & Dinâmica & Fatos & Consequências \\
\hline $\begin{array}{l}1991 \\
2000\end{array}$ & $\begin{array}{l}\text { Industrial } \\
\text { Passagem/Logística } \\
\text { Ambiental }\end{array}$ & & 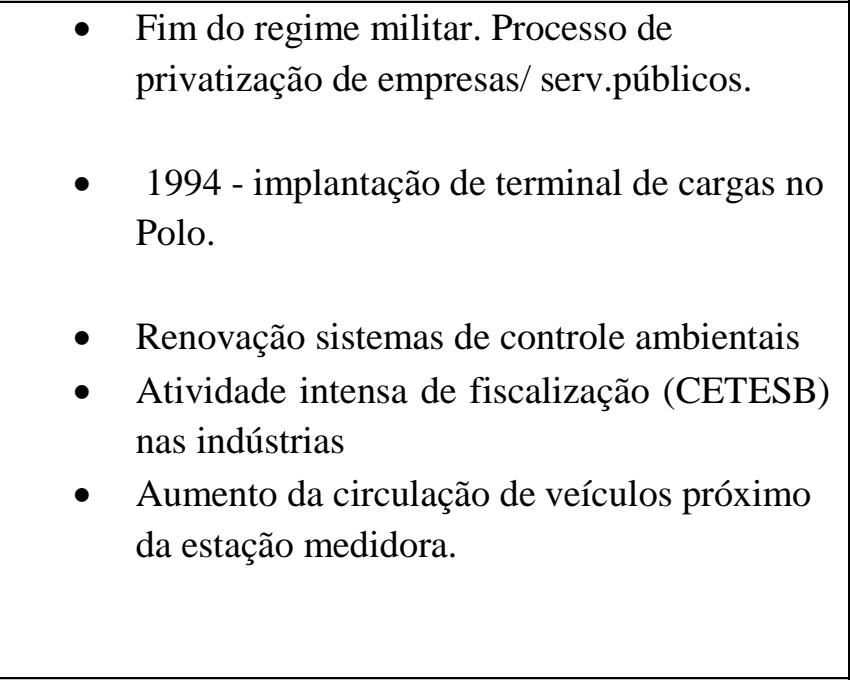 & $\begin{array}{l}\text { Desenvolvimento regional/nacional } \\
\text { - } \quad \text { Privatização - aporte de investimentos } \\
\text { - } \text { Aumento do tráfego } \\
\text { - } \quad \text { Qualidade do ar - melhoras nas condições } \\
\text { ambientais-recuperação. } \\
\text { - Produção das indústrias continua } \\
\text { - } \quad \text { rescendo- índices } \mathrm{MP}_{10} \text { diminuindo. } \\
\text { - índices } \\
\text { 1995 -plano de ações preventivas (CIESP } \\
\text { Cubatão) }\end{array}$ \\
\hline $\begin{array}{l}2001- \\
2013\end{array}$ & $\begin{array}{l}\text { Industrial } \\
\text { Logística }\end{array}$ & & $\begin{array}{l}\text { - Crise econômica mundial - } 2008 \text { e } 2009 \\
\text { - Pré-Sal - Petrobras. } \\
\text { - Programas - expansão do agronegócio, } \\
\text { exportações e expansão portuária. } \\
\checkmark \text { Super safras para o Porto de Santos } \\
\checkmark \text { Implantação dos pátios } \\
\text { - Especulação imobiliária - Baixada Santista } \\
\text { “canteiro de obras” } \\
\text { - Novos padrões de qualidade do ar mais }\end{array}$ & 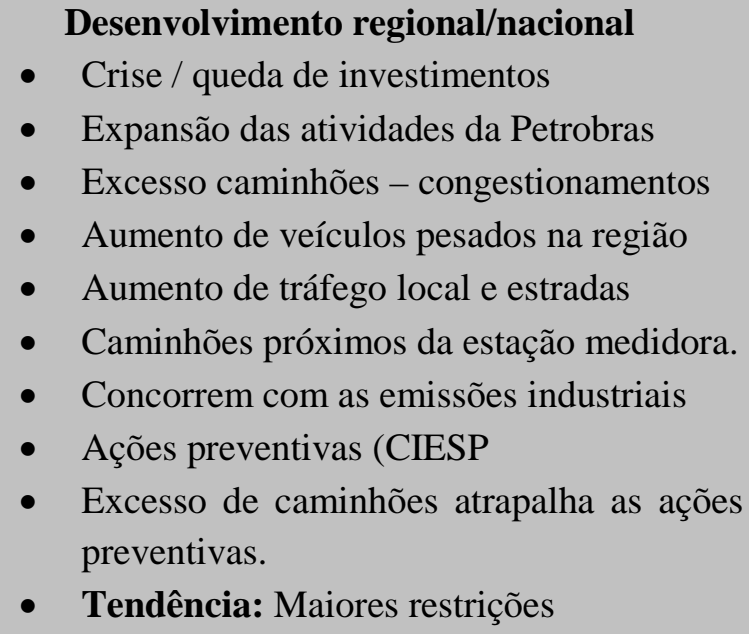 \\
\hline
\end{tabular}

Fonte: Elaboração própria 


\begin{tabular}{|c|c|}
\hline SÍMBOLOS & LEGENDA \\
\hline 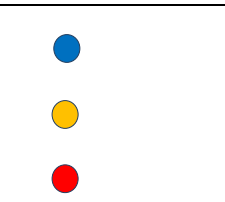 & $\begin{array}{l}\text { - Dinâmica de ocupação compatível com a disponibilidade de espaço e recursos. } \\
\text { - Dinâmica de ocupação começa a sofrer com incompatibilidade de utilização do espaço } \\
\text { - Dinâmica de ocupação sofre com a incompatibilidade de utilização do espaço e recursos }\end{array}$ \\
\hline$\underset{\mathrm{r}}{\longrightarrow}$ & $\begin{array}{l}\text { - Dinâmica ambiental sofre com a incompatibilidade - poluição intensa } \\
\text { - Dinâmica ambiental sinaliza as alterações positivas dos esforços de controle } \\
\text { - Dinâmica ambiental sinaliza as alterações positivas dos esforços de controle. }\end{array}$ \\
\hline$\Delta$ & $\begin{array}{l}\text { - Dinâmica de tráfego compatível com a capacidade da região - tráfego normal } \\
\text { - Dinâmica de tráfego começa a sinalizar a incompatibilidade com a capacidade - tráfego intenso e } \\
\text { congestionamentos eventuais } \\
\text { - Dinâmica de tráfego sofre com a incompatibilidade com a capacidade - congestionamentos frequentes }\end{array}$ \\
\hline
\end{tabular}

Fonte: Elaboração própria 


\section{Lattes}

\section{Mônica Silveira e Costa Cheng}

Possui graduação em Engenharia Química pela Universidade de Mogi das Cruzes (1987). Atualmente é Especialista de Meio Ambiente da USIMINAS - Usinas Siderurgicas de Minas Gerais. Tem experiência na área de Ciências Ambientais, com foco no acompanhamento de processos e recursos junto à CETESB e demais órgãos ambientais. Gerenciamento de estudos de investigação de áreas contaminadas e processos de reabilitação. Participação nos processos de licenciamento de grandes projetos, com foco na elaboração de estudos/relatórios de impactos ambientais (EIA/RIMA) junto à Secretaria de Meio Ambiente do Estado de São Paulo. Atuação junto ao mercado e comunidade. Atual Vice-coordenadora do PRODEMA (Comitê de Meio Ambiente das Indústrias do Pólo Industrial de Cubatão); experiência como representante do CIESP junto ao Comitê de gerenciamento costeiro da Baixada Santista (1998 a 2013) e Comitê de Bacia Hidrográfica da Baixada Santista (2008 a 2013); atual coordenadora da operação inverno do CIESP Cubatão (plano de ações preventivas), representante do IABr (siderurgia) junto à câmara técnica da CETESB; representante do CIESP Cubatão nas câmaras ambientais da FIESP; Representante do CIESP Cubatão no Conselho Consultivo do Parque Estadual da Serra do Mar. Treinamento no Japão e Venezuela.

\section{$\underline{\text { Sônia Maria Viggiani Coutinho }}$}

Possui graduação em Direito (1986), mestrado em Saúde Pública (2006) e doutorado em Ciências, linha de pesquisa Políticas Públicas e Gestão Ambiental, todos pela Universidade de São Paulo (2011). Atualmente realiza pós-doutorado na Universidade de São Paulo, com Bolsa Fapesp e é professora responsável da disciplina HSA 5759 na FSP/USP. É pesquisadora e coordenadora executiva da Rede SIADES - Sistema de Informações Ambientais para o Desenvolvimento Sustentável e pesquisadora do Núcleo de Apoio à Pesquisa em Mudanças Climáticas - NapMC/ INCLINE - INterdisciplinary CLimate INvestigation Center. Editora executiva da Revista Ambiente e Sociedade. Membro da International Association for Society and Natural Resources - IASNR. Atua na área de Ciências Ambientais e Interdisciplinar, principalmente nos seguintes temas: Mudanças Climáticas, Políticas Públicas e Gestão Ambiental, Indicadores de Sustentabilidade, Direito Ambiental e Urbanístico, Legislação Ambiental, Cidades e Saúde, Desenvolvimento Sustentável, Interdisciplinaridade e Redes Acadêmicas. 